Supporting Information

for

\title{
Cooperative weak dispersive interactions actuate catalysis in a shape-selective abiological racemase
}

\author{
Yujia Wang ${ }^{1}$, Michel Rickhaus ${ }^{1}$, Olivier Blacque ${ }^{1}$, Kim K. Baldridge ${ }^{2 *}$, \\ Michal Juríček ${ }^{1 *}$, Jay S. Siegel ${ }^{2 *}$ \\ ${ }^{1}$ Department of Chemistry, University of Zurich, Winterthurerstrasse 190, 8057 Zurich, Switzerland. \\ ${ }^{2}$ Health Sciences Platform, Tianjin University, 92 Weijin Road, Nankai District, Tianjin, 300072, P. R. China. \\ *Corresponding author. Email: kimbaldridge88@gmail.com, michal.juricek@chem.uzh.ch,dean_spst@tju.edu.cn
}




\section{Table of contents}

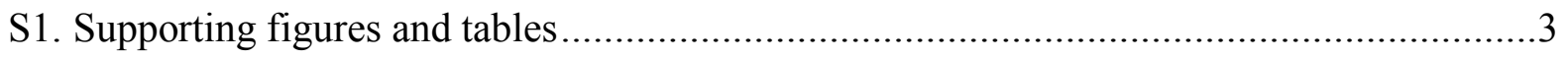

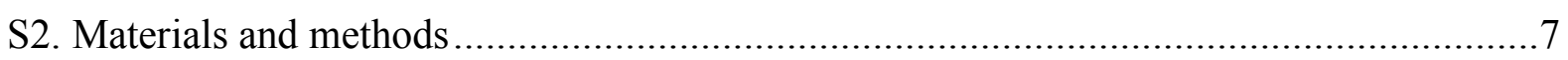

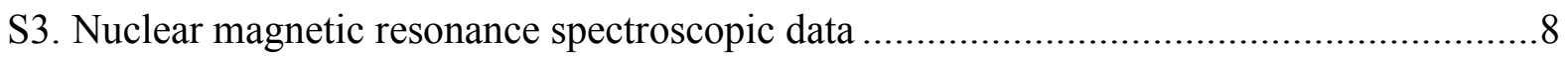

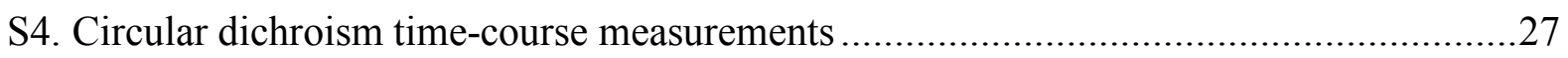

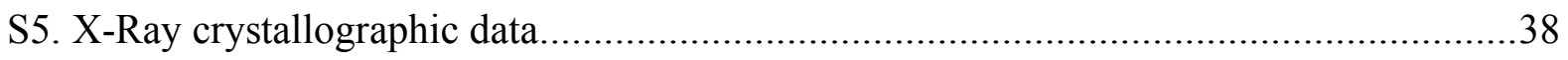

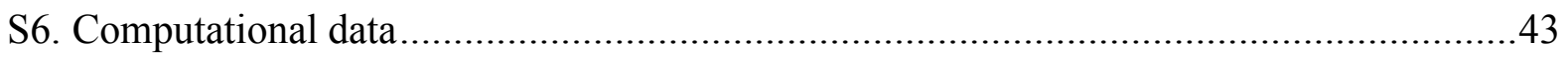

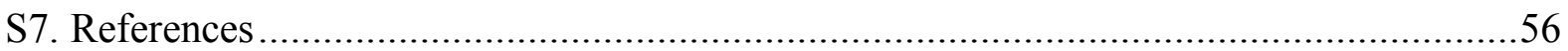




\section{S1. Supporting figures and tables}

shape match

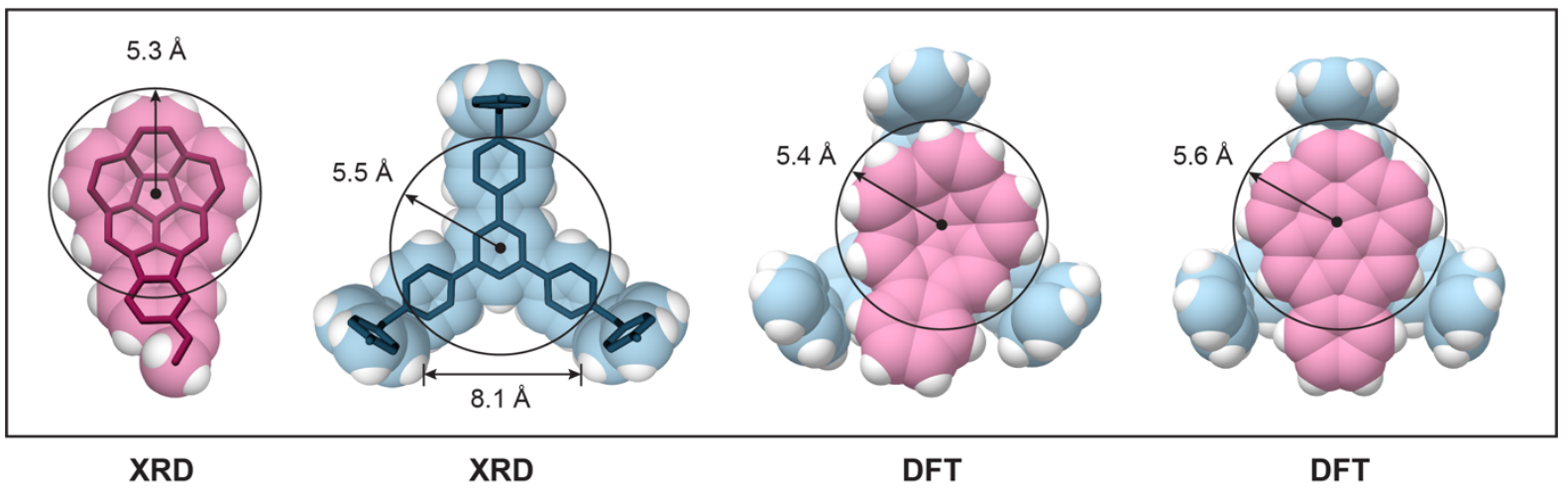

Fig. S1. Shape match between iCor and ExCage. From left to right: van der Waals radius of iCor $^{1}$ and ExCage ${ }^{2}$ obtained from XRD, and of bowl-shaped iCor in iCorCExCage and flat iCor in iCorсExCage obtained from DFT. Analyzed in the Mercury program.

\section{bowl-to-bowl flip shape analysis}

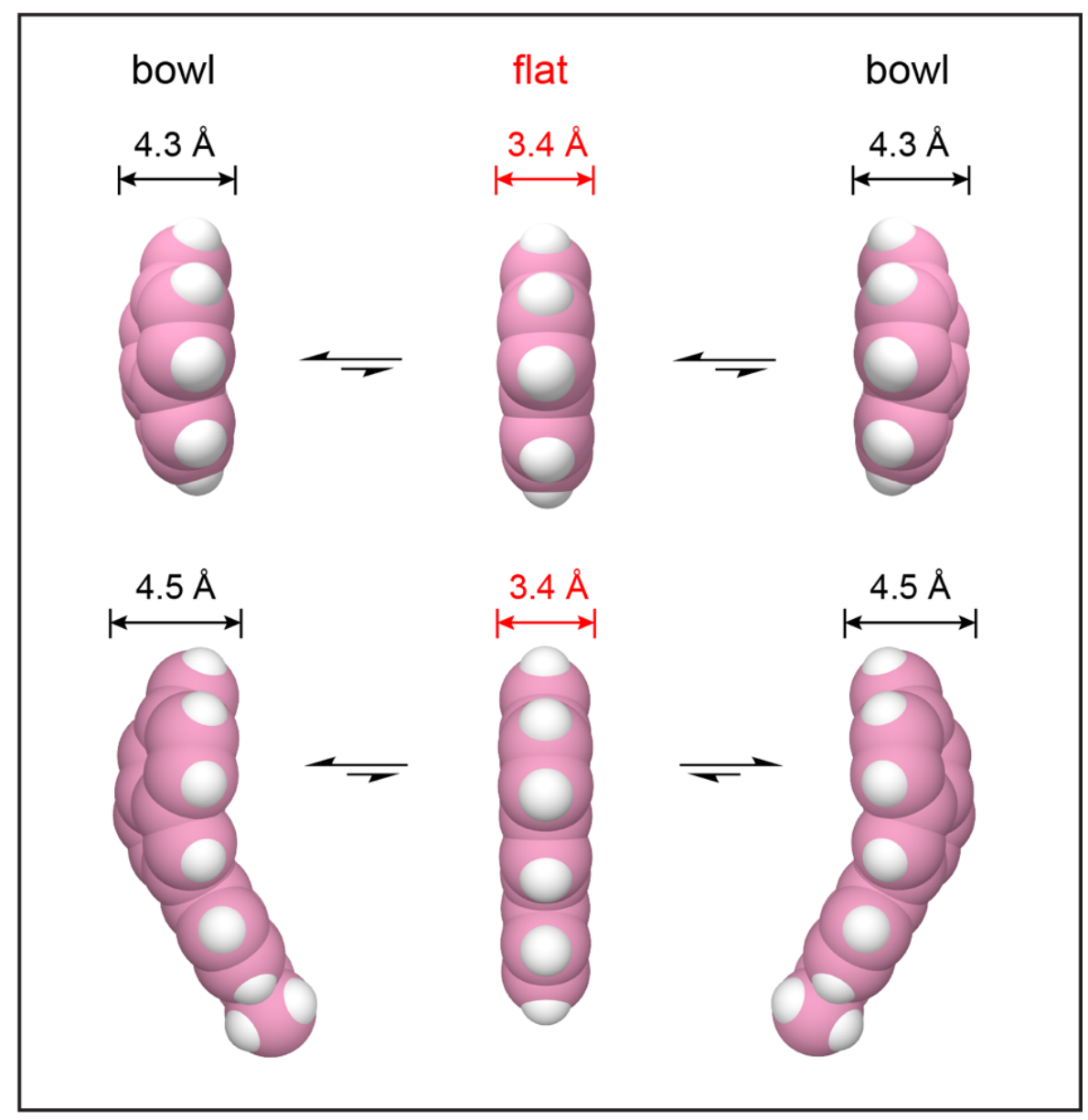

Fig. S2. Bowl-to-bowl flip shape analysis of Cor and iCor. The change of the van der Walls bowl depth of Cor (top) and iCor (bottom) during the bowl-to-bowl flip via flat transition state. The ground-state structures were obtained from XRD, while the transition-state structures from DFT. The Mercury program was used to determine the van der Waals bowl depth. 


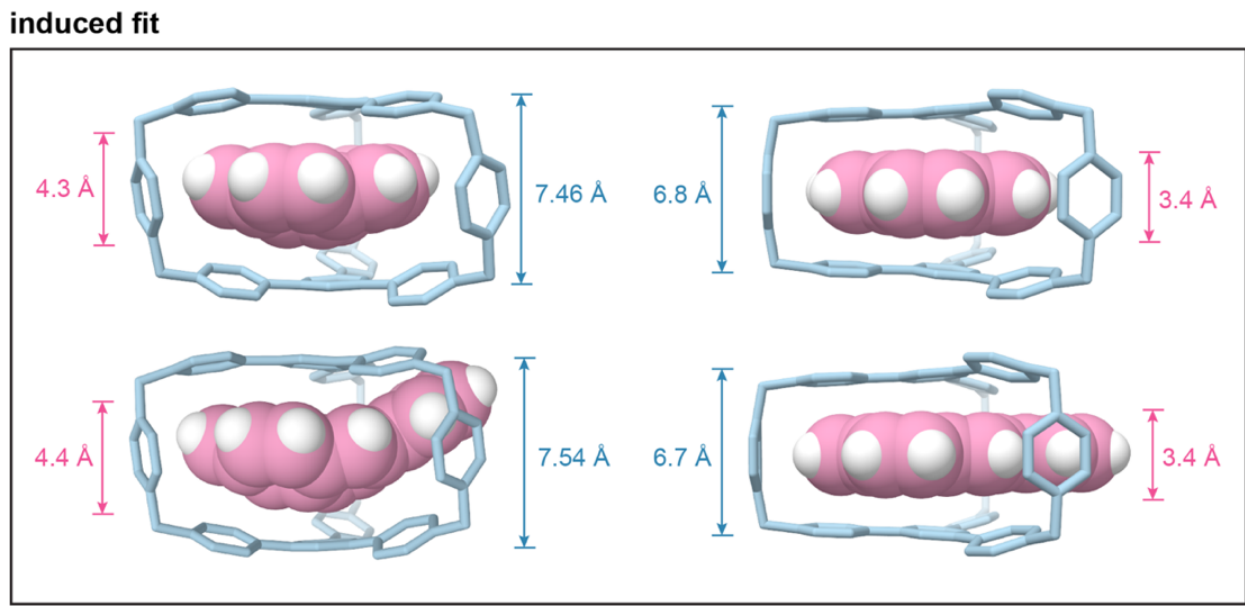

Fig. S3. Shape-complementarity in Cor $\subset$ ExCage and iCorcExCage. From top left to bottom right: the ground and transition state of CorCExCage and the ground and transition state of iCor $\subset$ ExCage. The ground-state structure of Cor CExCage was obtained from XRD, and the transition-state structure of Cor $\subset$ ExCage, the ground-state structure of iCor $\subset$ ExCage, and the transition-state structure of iCorCExCage from DFT. The Mercury program was used to determine the van der Waals dimensions. 
Table S1. Enantiomerization rate constants $(k)$ and activation energies $\left(\Delta G^{\ddagger}\right)$ for the noncatalyzed (non) and ExCage-catalyzed (cat) bowl-to-bowl inversion of iCor in $\mathrm{CH}_{3} \mathrm{CN}$.

\begin{tabular}{|c|c|c|c|c|c|c|c|c|c|}
\hline \multicolumn{3}{|c|}{ Racemization } & \multicolumn{7}{|c|}{ Enantiomerization } \\
\hline $\begin{array}{c}T \\
(\mathbf{K})\end{array}$ & $\begin{array}{l}t_{1 / 2 \text { non }^{\mathrm{a}}} \\
\text { (h) }\end{array}$ & $\begin{array}{l}t_{1 / 2 \text { cat }} \text { b } \\
\text { (h) }\end{array}$ & $\begin{array}{l}k_{\text {non }}{ }^{\mathrm{c}} \\
\left(\mathrm{s}^{-1}\right)\end{array}$ & $\begin{array}{l}k_{\mathrm{obs}}{ }^{\mathrm{c}} \\
\left(\mathrm{s}^{-1}\right)\end{array}$ & $\begin{array}{c}K_{\mathrm{a}}{ }^{\mathrm{d}} \\
\left(10 \times M^{-1}\right)\end{array}$ & $\begin{array}{l}k_{\text {cat }}{ }^{\mathrm{e}} \\
\left(\mathrm{s}^{-1}\right)\end{array}$ & $\boldsymbol{k}_{\mathrm{cat}} / \boldsymbol{k}_{\mathrm{non}}{ }^{\mathrm{f}}$ & $\begin{array}{c}\Delta G^{\ddagger}{ }^{\mathrm{g}}{ }^{-1} \\
\left(\mathrm{kcal} \mathrm{mol}^{-1}\right)\end{array}$ & $\begin{array}{c}\Delta G^{\ddagger} \text { cat }^{\mathrm{h}} \\
\left(\mathrm{kcal} \mathrm{mol}^{-1}\right)\end{array}$ \\
\hline 373 & 0.52 & $3.3 \times 10^{-4}$ & $1.9 \times 10^{-4}$ & $3.8 \times 10^{-3}$ & 2.3 & $2.9 \times 10^{-1}$ & $1.5 \times 10^{3}$ & 28.4 & 22.9 \\
\hline 363 & 1.5 & $6.7 \times 10^{-4}$ & $6.2 \times 10^{-5}$ & $2.1 \times 10^{-3}$ & 2.7 & $1.4 \times 10^{-1}$ & $2.3 \times 10^{3}$ & 28.3 & 22.8 \\
\hline 353 & 2.8 & $1.4 \times 10^{-3}$ & $3.4 \times 10^{-5}$ & $1.1 \times 10^{-3}$ & 3.1 & $6.7 \times 10^{-2}$ & $2.0 \times 10^{3}$ & 28.3 & 22.7 \\
\hline 343 & 16 & $3.2 \times 10^{-3}$ & $6.1 \times 10^{-6}$ & $6.0 \times 10^{-4}$ & 3.7 & $3.0 \times 10^{-2}$ & $4.9 \times 10^{3}$ & 28.2 & 22.6 \\
\hline 333 & 39 & $6.5 \times 10^{-3}$ & $2.5 \times 10^{-6}$ & $\begin{array}{c}3.5 \times 10^{-4} \\
\left(4.1 \times 10^{-3}\right)\end{array}$ & $\begin{array}{c}4.4 \\
\mathbf{( 6 . 9} \pm \mathbf{8 . 2})\end{array}$ & $1.5 \times 10^{-2}$ & $\begin{array}{c}6.0 \times 10^{3} \\
\left(\mathbf{1 . 6} \times \mathbf{1 0}^{3}\right)\end{array}$ & 28.2 & 22.5 \\
\hline 323 & $1.4 \times 10^{2}$ & $2.1 \times 10^{-2}$ & $6.7 \times 10^{-7}$ & $1.3 \times 10^{-4}$ & 5.3 & $4.6 \times 10^{-3}$ & $6.9 \times 10^{3}$ & 28.1 & 22.3 \\
\hline 313 & $5.5 \times 10^{2}$ & $4.4 \times 10^{-2}$ & $1.7 \times 10^{-7}$ & $\begin{array}{c}7.4 \times 10^{-5} \\
\left(1.2 \times 10^{-3}\right)\end{array}$ & $\begin{array}{c}6.5 \\
\mathbf{( 7 . 3} \pm \mathbf{4 . 5})\end{array}$ & $2.2 \times 10^{-3}$ & $\begin{array}{c}1.3 \times 10^{4} \\
\left(7.1 \times 10^{3}\right)\end{array}$ & 28.0 & 22.2 \\
\hline 303 & $2.3 \times 10^{3}$ & 0.17 & $4.2 \times 10^{-8}$ & $2.4 \times 10^{-5}$ & 8.0 & $5.8 \times 10^{-4}$ & $1.5 \times 10^{4}$ & 28.0 & 22.1 \\
\hline 293 & $1.1 \times 10^{4}$ & 0.34 & $9.0 \times 10^{-9}$ & $1.4 \times 10^{-5}$ & $\begin{array}{c}10 \\
\mathbf{( 1 2} \pm \mathbf{5 . 8})\end{array}$ & $2.8 \times 10^{-4}$ & $3.1 \times 10^{4}$ & 28.0 & 22.0 \\
\hline 283 & $5.5 \times 10^{4}$ & 1.3 & $1.8 \times 10^{-9}$ & $\begin{array}{c}5.0 \times 10^{-6} \\
\left(6.5 \times 10^{-5}\right)\end{array}$ & 13 & $7.7 \times 10^{-5}$ & $\begin{array}{c}4.3 \times 10^{4} \\
\left(3.6 \times 10^{4}\right)\end{array}$ & 27.9 & 21.9 \\
\hline 273 & $3.2 \times 10^{5}$ & 4.4 & $3.0 \times 10^{-10}$ & $1.8 \times 10^{-7}$ & $\begin{array}{c}16 \\
\mathbf{( 1 7} \pm \mathbf{6 . 4})\end{array}$ & $2.2 \times 10^{-5}$ & $7.3 \times 10^{4}$ & 27.8 & 21.8 \\
\hline 258 & $5.7 \times 10^{6}$ & 34 & $1.7 \times 10^{-11}$ & $3.4 \times 10^{-7}$ & $\begin{array}{c}25 \\
(26 \pm \mathbf{9 . 0})\end{array}$ & $2.9 \times 10^{-6}$ & $1.7 \times 10^{5}$ & 27.8 & 21.6 \\
\hline
\end{tabular}

a, $t_{1 / 2 \text { non }}=\ln 2 / k_{\text {rac non }}=\ln 2 / 2 k_{\text {non }}$ b $t_{1 / 2 \text { cat }}=\ln 2 / k_{\text {rac cat }}=\ln 2 / 2 k_{\text {cat }}$. c, the values in bold were obtained experimentally by following the decay of the CD signal; the values not in bold were extrapolated from the Eyring plot (Figure S30 for $\left.k_{\text {non }}\right)$. The $k_{\text {obs }}$ values in the brackets in bold were obtained experimentally by following the decay of the CD signal with 137 equivalents of ExCage. d, the values in bold were obtained experimentally from four independent measurements and the values not in bold were extrapolated from the Van't Hoff plot obtained from four independent measurements (Figure S19). e, the values in the temperature range $283-333 \mathrm{~K}$ were calculated by using the equation $k_{\mathrm{obs}}=a k_{\mathrm{cat}}+(1$

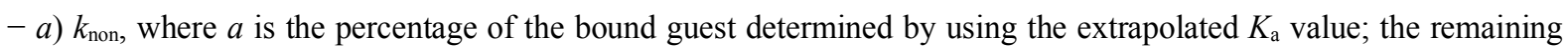
values were extrapolated from the Eyring plot (Figure S37). f, The values in the brackets at 283, 313 and $333 \mathrm{~K}$ were calculated using the $k_{\text {obs }}$ values in the bracket instead of $k_{\text {cat. }}$ g, calculated using $\Delta H_{\text {non }}^{\ddagger}=26.4 \mathrm{kcal} \mathrm{mol}^{-1}$ and $\Delta S^{\ddagger}$ non $=$ $-5.26 \mathrm{cal} \mathrm{mol}^{-1} \mathrm{~K}^{-1}$ obtained from the Eyring plot (Figure S30). h, calculated using $\Delta H_{\text {cat }}^{\ddagger}=18.6 \mathrm{kcal} \mathrm{mol}^{-1}$ and $\Delta S_{\text {cat }}^{\ddagger}$ $=-11.7 \mathrm{cal} \mathrm{mol}^{-1} \mathrm{~K}^{-1}$ obtained from the Eyring plot (Figure S37). 
Table S2. Enantiomerization rate constants $(k)$ of iCor and iCor $\subset$ ExCage with low catalyst load at $313 \mathrm{~K}$.

\begin{tabular}{|c|c|c|c|c|c|c|}
\hline \multicolumn{3}{|c|}{ Racemization } & \multicolumn{4}{|c|}{ Enantiomerization } \\
\hline ExCage & $\begin{array}{c}t_{1 / 2} \text { non }^{a} \\
\text { (h) }\end{array}$ & $\begin{array}{c}t_{1 / 2} \text { obs }^{\mathrm{a}} \\
\text { (h) }\end{array}$ & $\begin{array}{l}k_{\text {non }}{ }^{b} \\
\left(s^{-1}\right)\end{array}$ & $\begin{array}{l}k_{0 b s}{ }^{b} \\
\left(s^{-1}\right)\end{array}$ & $\begin{array}{c}K_{\mathrm{a}} \mathrm{c} \\
\left(\mathbf{M}^{-1}\right)\end{array}$ & $\begin{array}{l}k_{\text {cat }}{ }^{d} \\
\left(s^{-1}\right)\end{array}$ \\
\hline $7.5 \%$ & $5.5 \times 10^{2}$ & 49 & $1.7 \times 10^{-7}$ & $2.0 \times 10^{-6}$ & 65 & $2.0 \times 10^{-3}$ \\
\hline $10 \%$ & $5.5 \times 10^{2}$ & 36 & $1.7 \times 10^{-7}$ & $2.7 \times 10^{-6}$ & 65 & $2.8 \times 10^{-3}$ \\
\hline $20 \%$ & $5.5 \times 10^{2}$ & 35 & $1.7 \times 10^{-7}$ & $2.8 \times 10^{-6}$ & 65 & $2.9 \times 10^{-3}$ \\
\hline $40 \%$ & $5.5 \times 10^{2}$ & 33 & $1.7 \times 10^{-7}$ & $2.9 \times 10^{-6}$ & 65 & $3.0 \times 10^{-3}$ \\
\hline $50 \%$ & $5.5 \times 10^{2}$ & 22 & $1.7 \times 10^{-7}$ & $4.5 \times 10^{-6}$ & 65 & $4.7 \times 10^{-3}$ \\
\hline $500 \%$ & $5.5 \times 10^{2}$ & 1.3 & $1.7 \times 10^{-7}$ & $7.4 \times 10^{-5}$ & 65 & $3.0 \times 10^{-3}$ \\
\hline
\end{tabular}

a, $t_{1 / 2}=\ln 2 / k_{\text {rac }}=\ln 2 / 2 k$. b, the values were obtained experimentally by following the decay of the CD signal (fig. 38-42). c, the values were extrapolated from the Van't Hoff plot obtained from four independent measurements (fig. $\mathrm{S} 19)$. $\mathrm{d}$, the values were calculated by using the equation $k_{\mathrm{obs}}=a k_{\mathrm{cat}}+(1-a) k_{\mathrm{non}}$, where $a$ is the percentage of the bound guest determined by using the $K_{\mathrm{a}}$ value. 


\section{S2. Materials and methods}

All reagents were purchased from commercial suppliers and used without further purification unless stated otherwise. 2-Methoxyindenocorannulene (iCor), ${ }^{1}$ ExCage $6 \mathrm{PF}_{6}{ }^{2}$, and corannulene $^{3}$ were synthesized as previously reported. Nuclear magnetic resonance (NMR) spectra were recorded on a Bruker Avance III $600 \mathrm{MHz}$, Bruker Avance III $500 \mathrm{MHz}$ and Bruker Avance III $400 \mathrm{MHz}$ NMR spectrometers. The signal corresponding to the residual non-deuterated solvent $\left(\mathrm{Me}_{2} \mathrm{CO}-d_{6}: \delta_{\mathrm{H}}=2.05 \mathrm{ppm} ; \mathrm{MeCN}-d_{3}: \delta_{\mathrm{H}}=1.94 \mathrm{ppm}\right)$ was used as a reference. Kinetic studies were recorded on a J-1000 Series Circular Dichroism (CD) Spectropolarimeter. 


\section{S3. Nuclear magnetic resonance spectroscopic data}

a

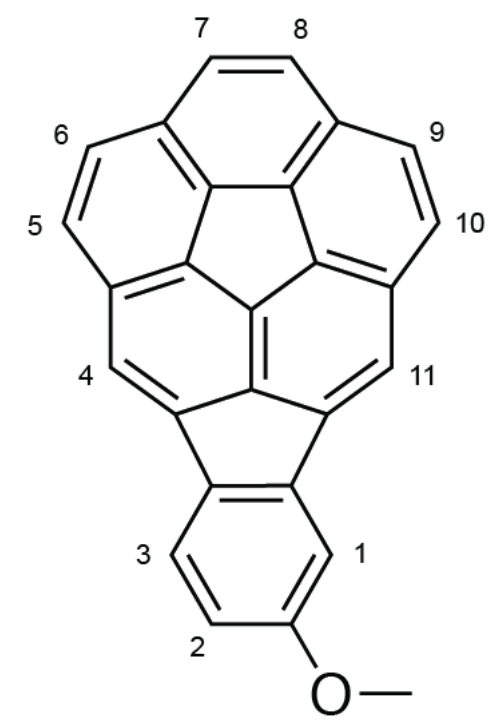

C

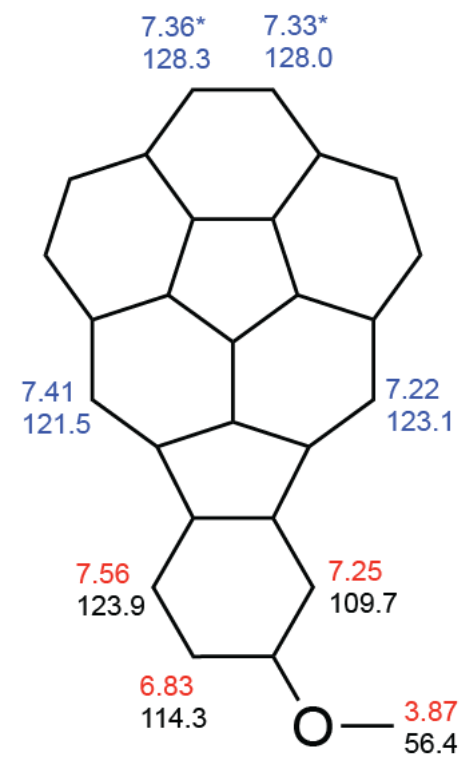

b

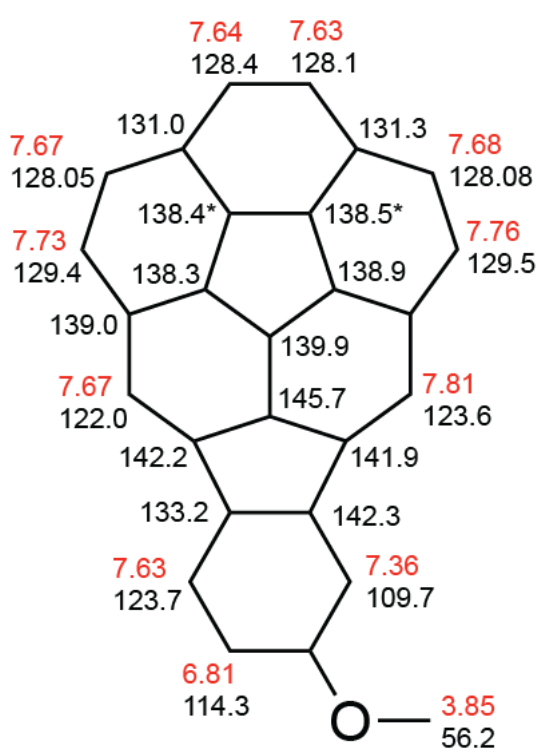

d

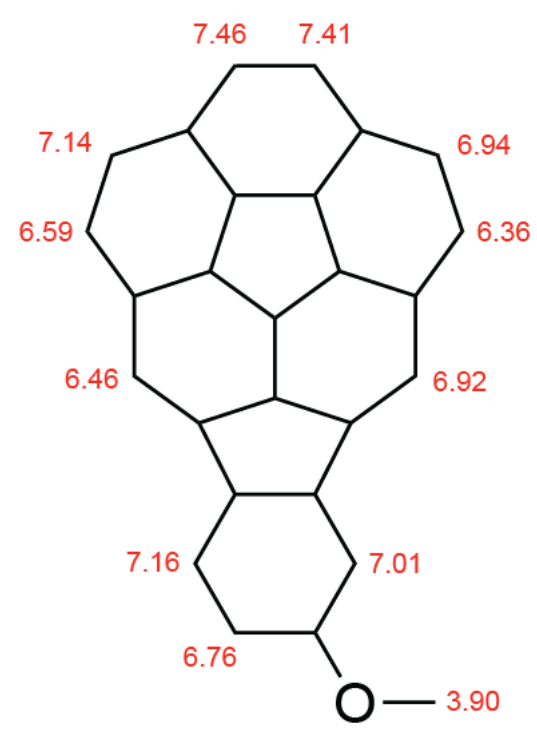

Fig. S4. Assignment of ${ }^{1} \mathrm{H}$ and ${ }^{13} \mathrm{C}$ resonances for iCor and its complex with ExCage. a, proton labeling of iCor. b, ${ }^{1} \mathrm{H}$ (red) and ${ }^{13} \mathrm{C}$ (black) chemical shifts of iCor (* or vice versa), c, ${ }^{1} \mathrm{H}$ (red) and ${ }^{13} \mathrm{C}$ (black) chemical shifts of iCorCExCage (signals in blue were assigned based on the similarity of ${ }^{13} \mathrm{C}$ signals of iCor and iCorCExCage; * or vice versa, COSY correlation), d, ${ }^{1} \mathrm{H}$ (red) chemical shifts of iCorCExBox. 


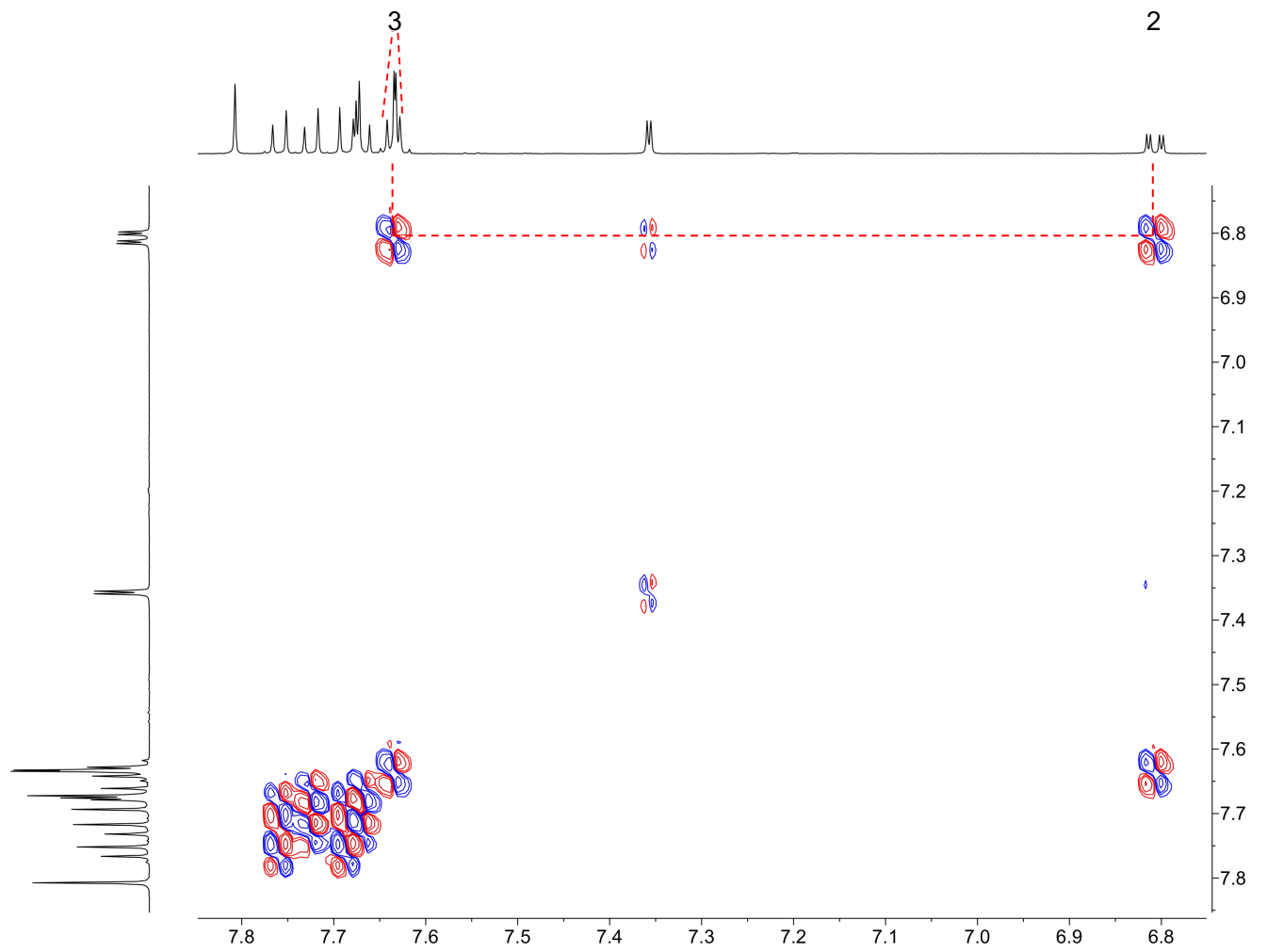

Fig. S5. ${ }^{1} \mathrm{H}-{ }^{1} \mathrm{H}$ COSY NMR $\left(600 \mathrm{MHz}, \mathrm{CD}_{3} \mathrm{CN}\right.$, ppm) spectrum of iCor.

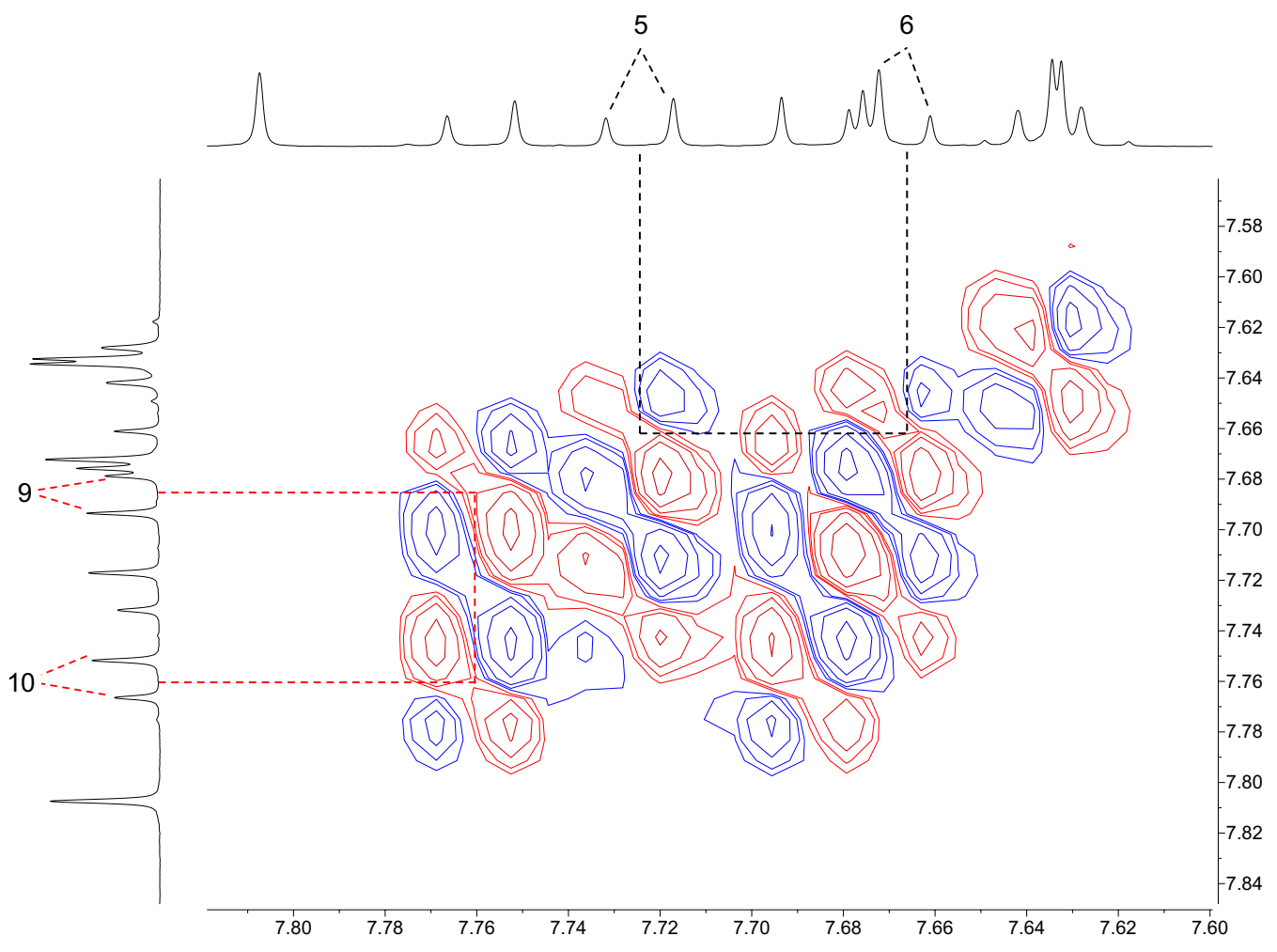

Fig. S6. ${ }^{1} \mathrm{H}-{ }^{1} \mathrm{H}$ COSY NMR (600 MHz, $\mathrm{CD}_{3} \mathrm{CN}$, ppm) spectrum of iCor (zoom). 


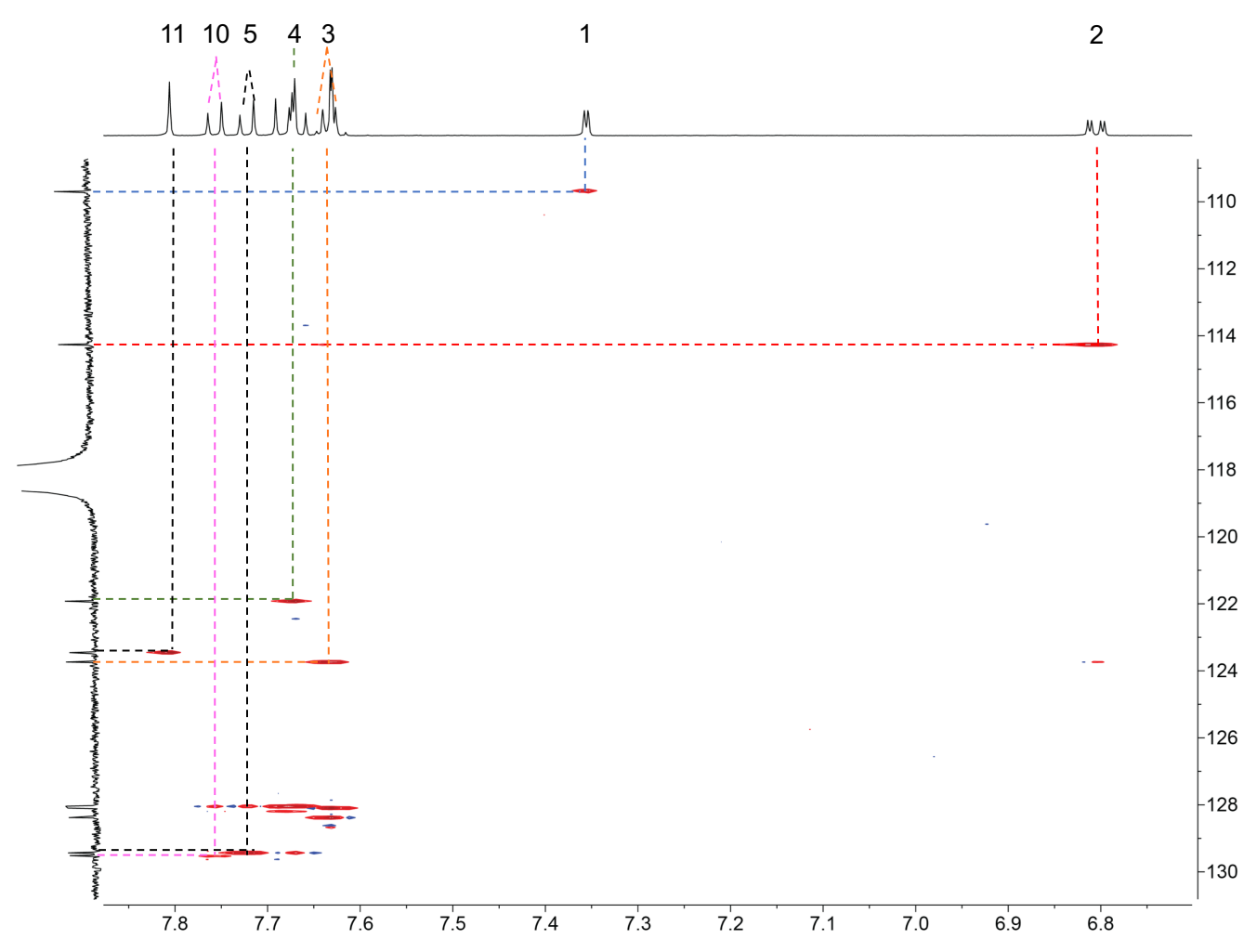

Fig. S7. ${ }^{1} \mathrm{H}-{ }^{13} \mathrm{C}$ HSQC NMR (600 MHz, $\mathrm{CD}_{3} \mathrm{CN}$, ppm) spectrum of iCor.

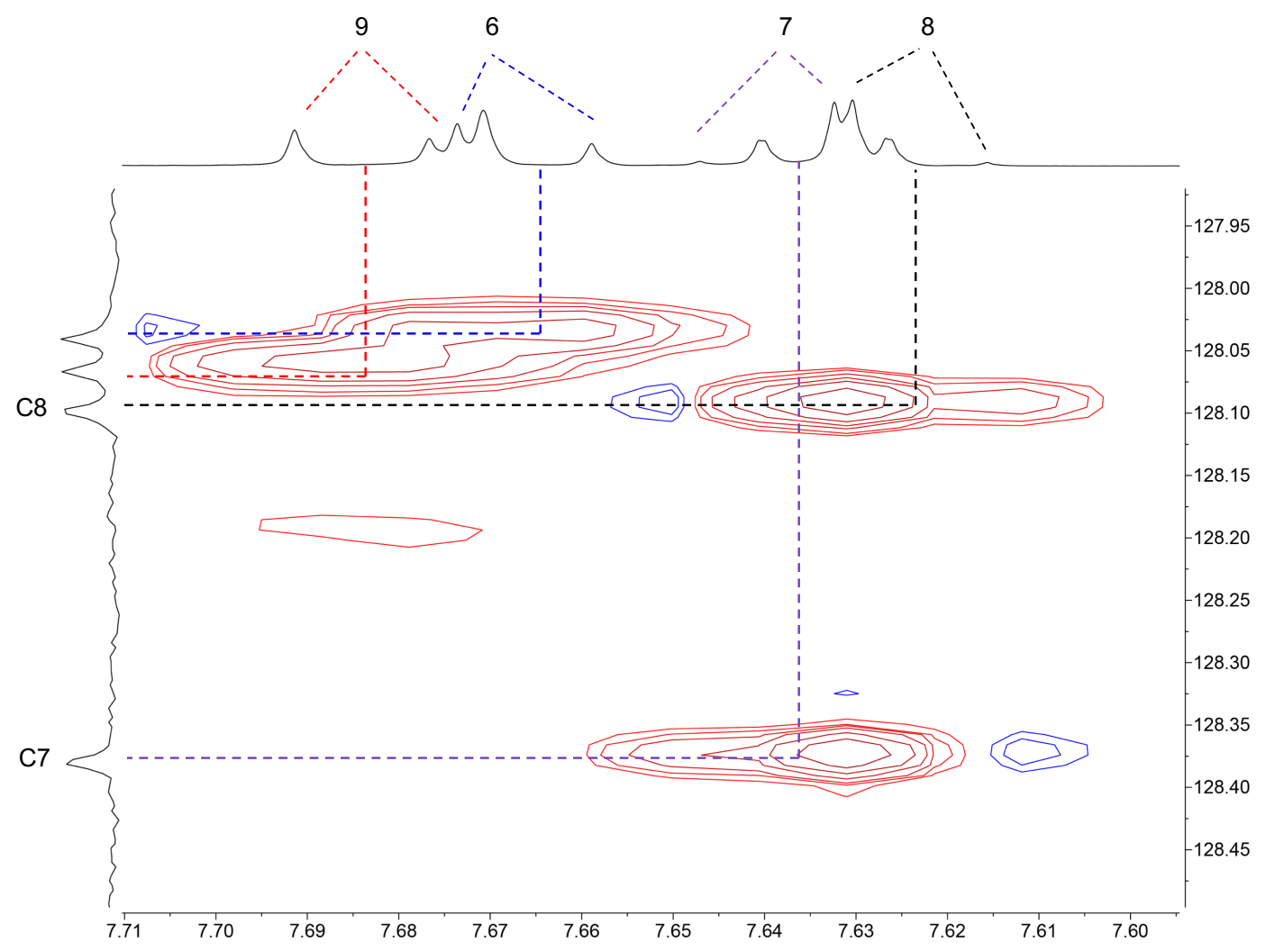

Fig. S8. ${ }^{1} \mathrm{H}-{ }^{13} \mathrm{C}$ HSQC NMR (600 MHz, $\mathrm{CD}_{3} \mathrm{CN}$, ppm) spectrum of iCor (zoom). 


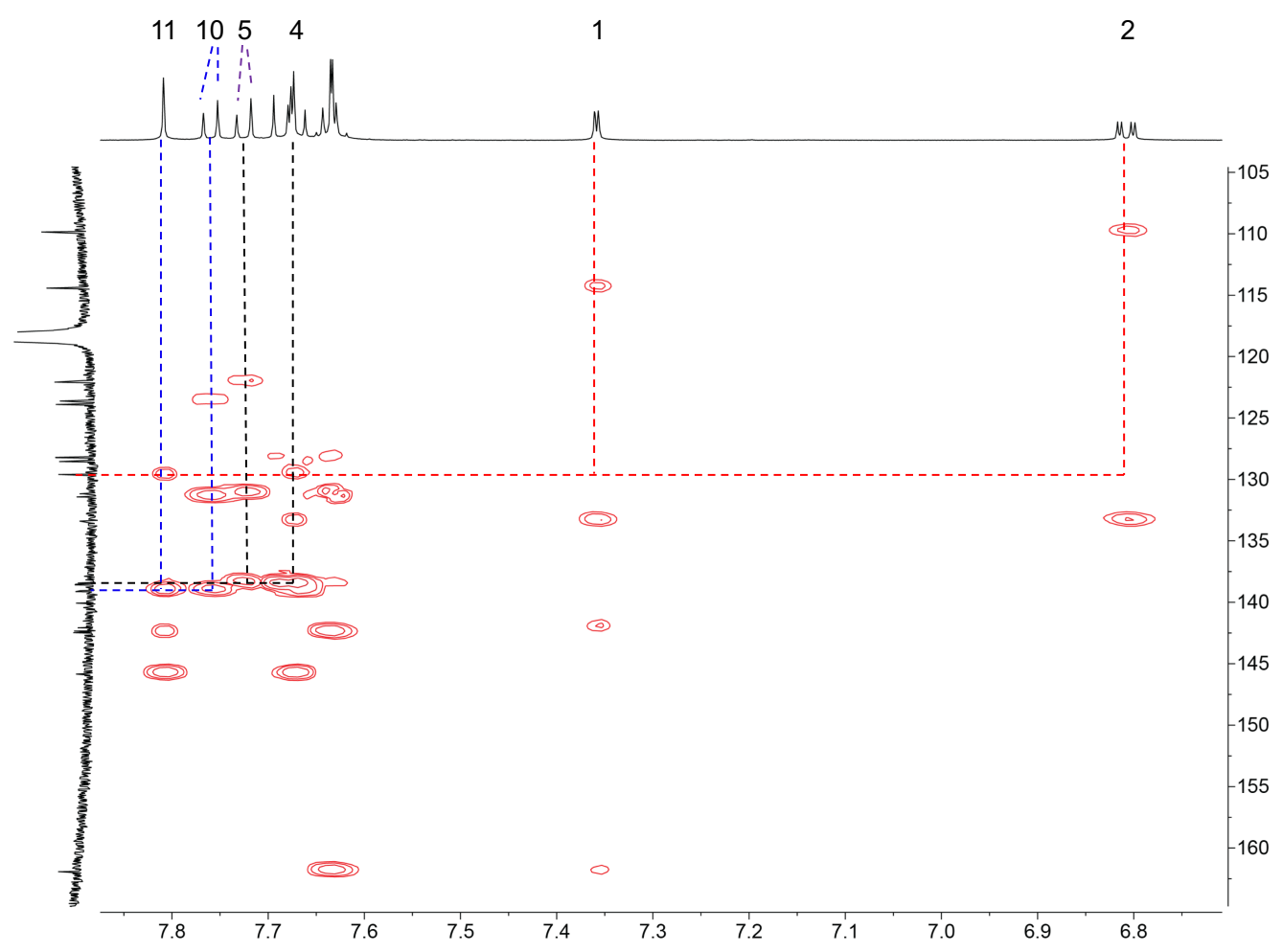

Fig. S9. ${ }^{1} \mathrm{H}-{ }^{13} \mathrm{C} \mathrm{HMBC} \mathrm{NMR}\left(600 \mathrm{MHz}, \mathrm{CD}_{3} \mathrm{CN}\right.$, ppm) spectrum of iCor.

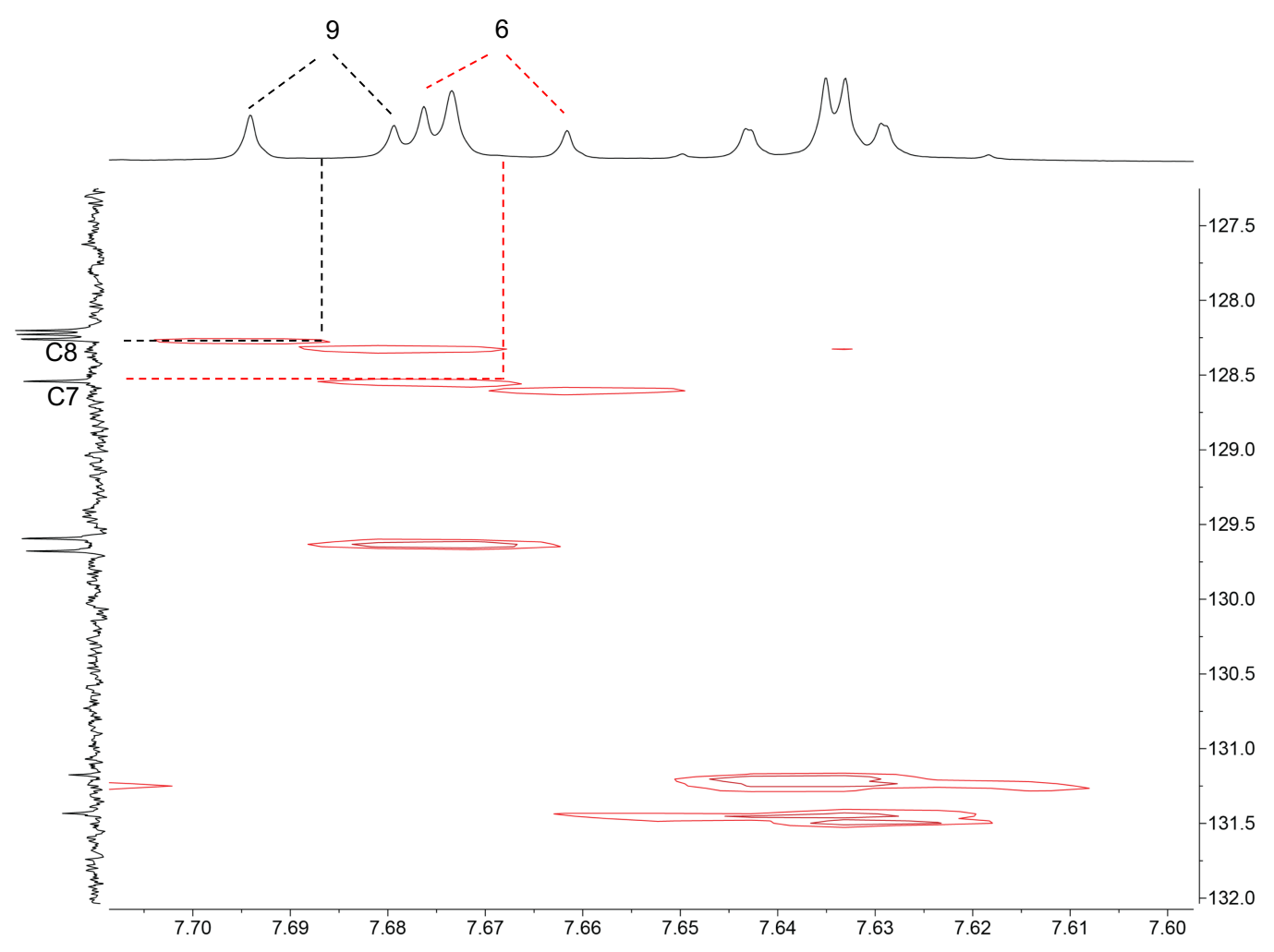

Fig. S10. ${ }^{1} \mathrm{H}-{ }^{13} \mathrm{C}$ HMBC NMR (600 MHz, $\mathrm{CD}_{3} \mathrm{CN}$, ppm) spectrum of iCor (zoom). 


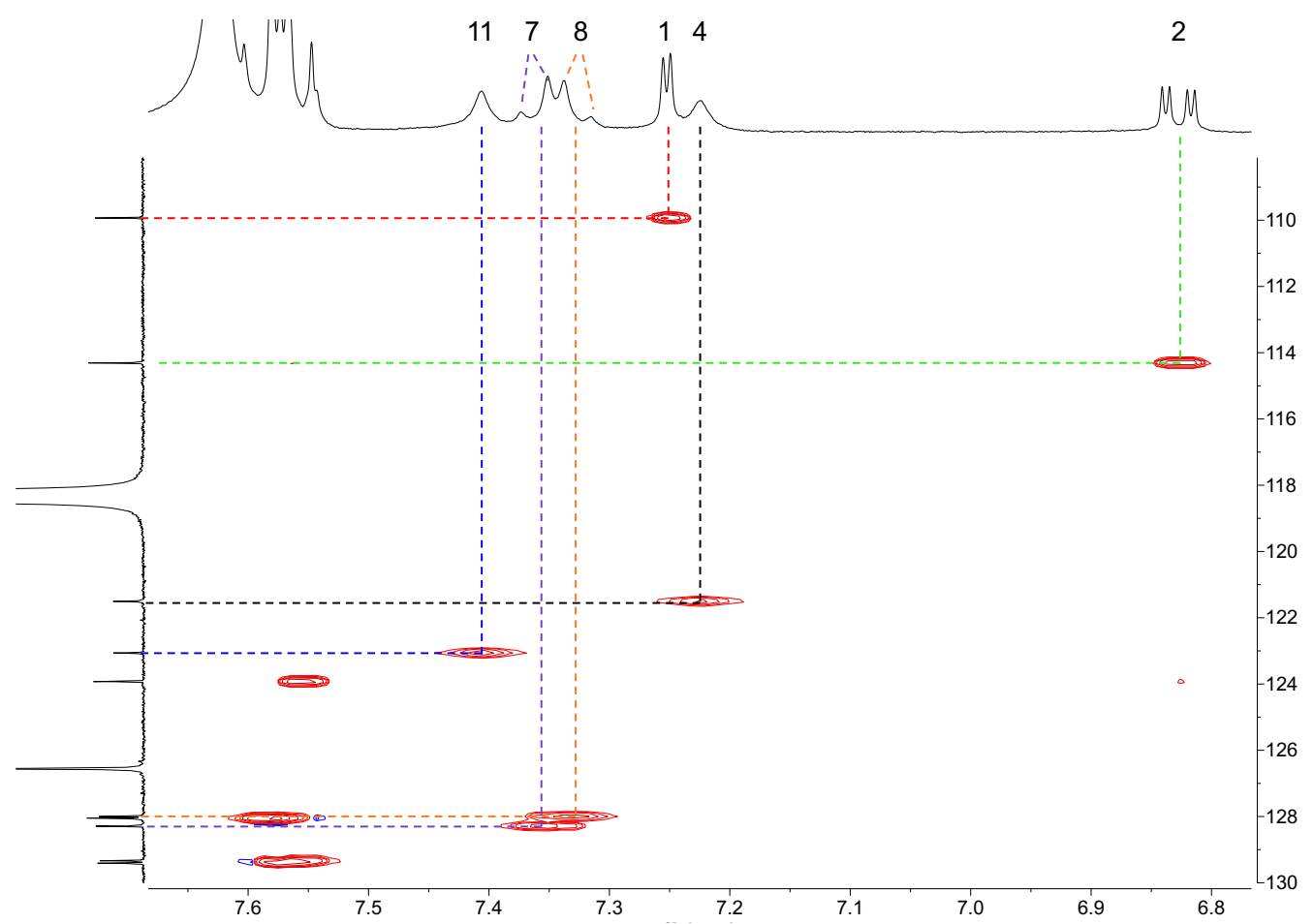

Fig. S11. ${ }^{1} \mathrm{H}-{ }^{13} \mathrm{C}$ HSQC NMR $\left(600 \mathrm{MHz}, \mathrm{CD}_{3} \mathrm{CN}\right.$, ppm) spectrum of iCorCExCage.

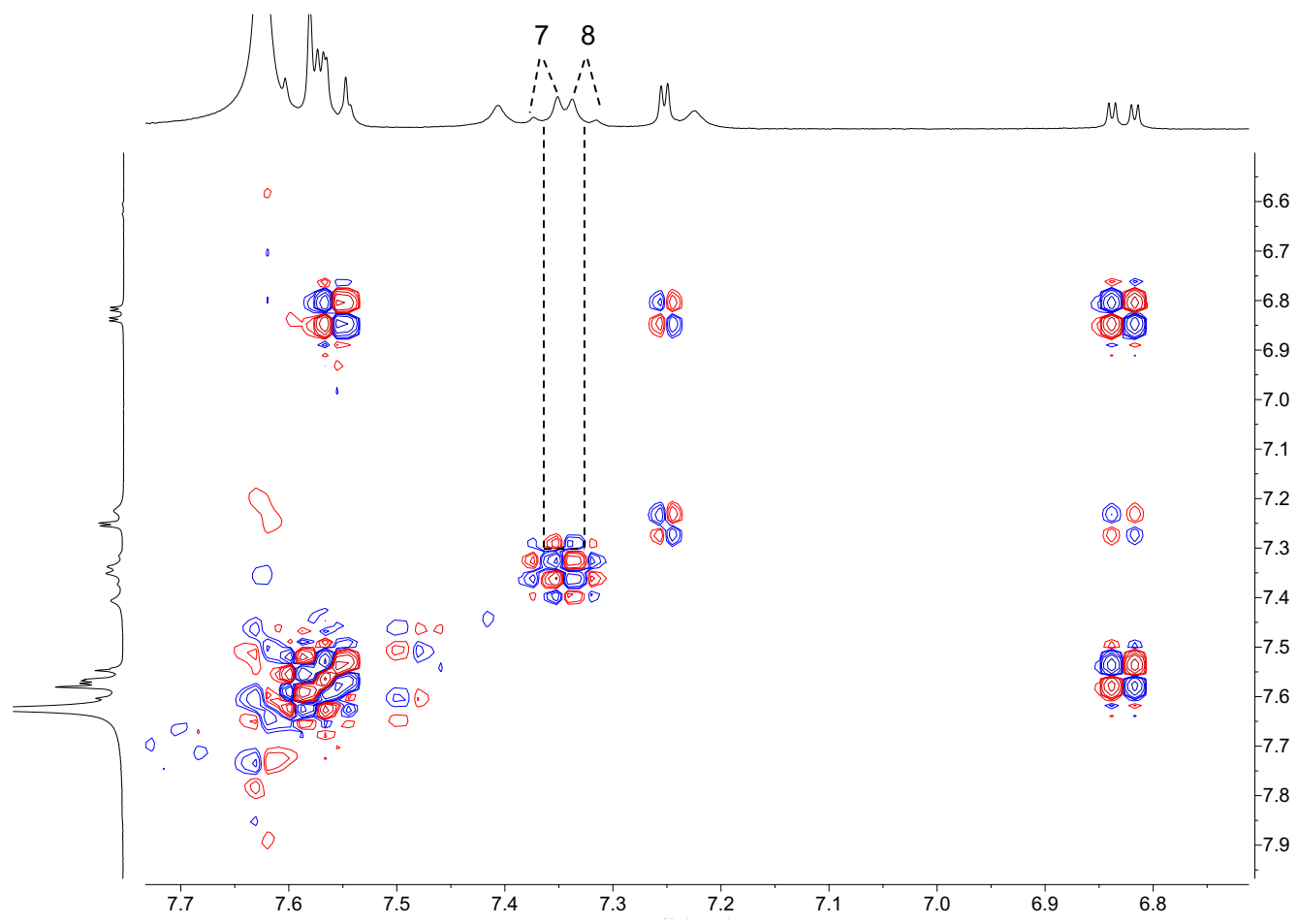

Fig. S12. ${ }^{1} \mathrm{H}-{ }^{1} \mathrm{H}$ COSY NMR $\left(600 \mathrm{MHz}, \mathrm{CD}_{3} \mathrm{CN}\right.$, ppm) spectrum of iCor $\subset$ ExCage. 


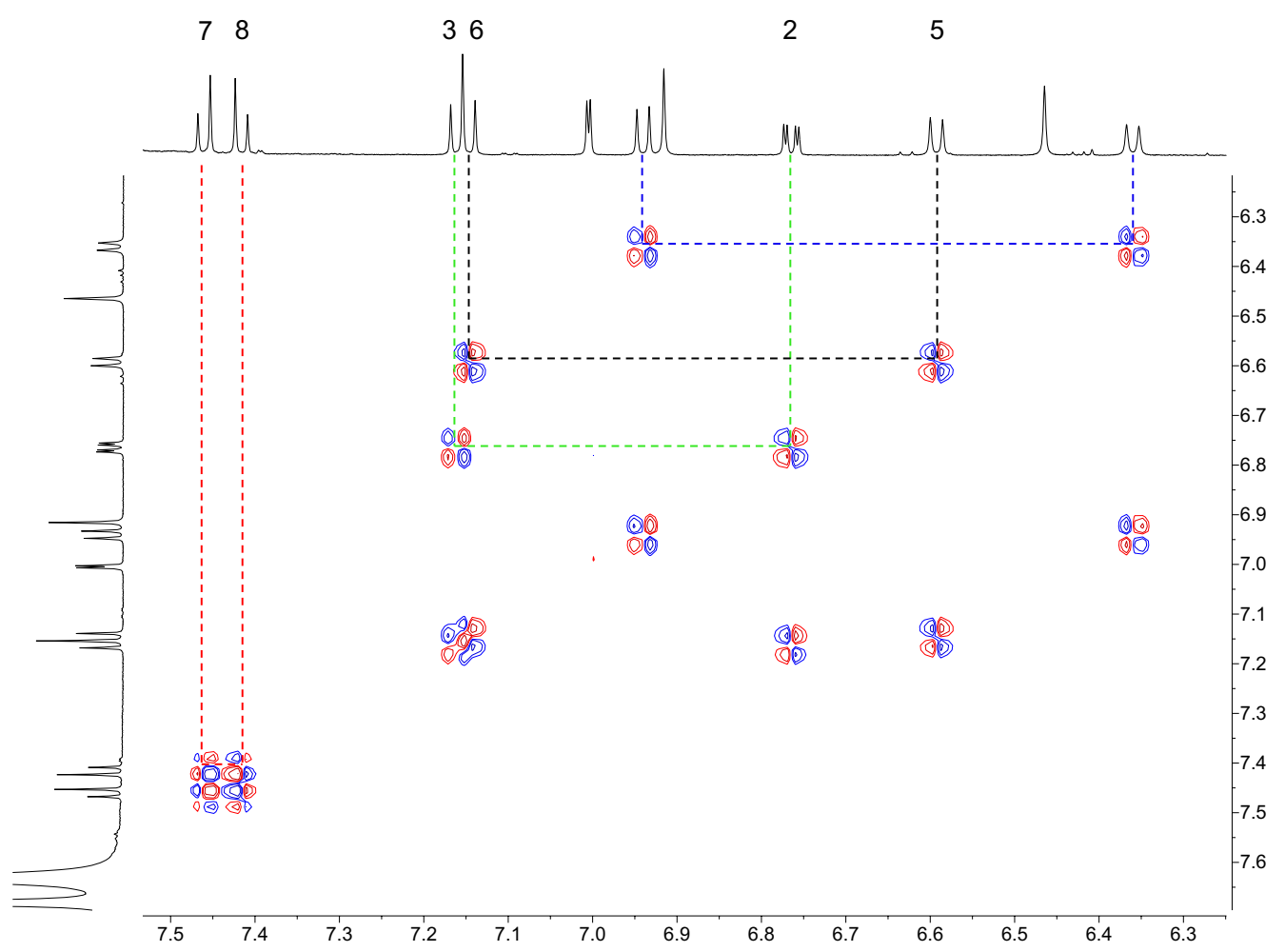

Fig. S13. ${ }^{1} \mathrm{H}-{ }^{1} \mathrm{H}$ COSY NMR $\left(600 \mathrm{MHz}, \mathrm{CD}_{3} \mathrm{CN}\right.$, ppm) spectrum of iCorсExBox.

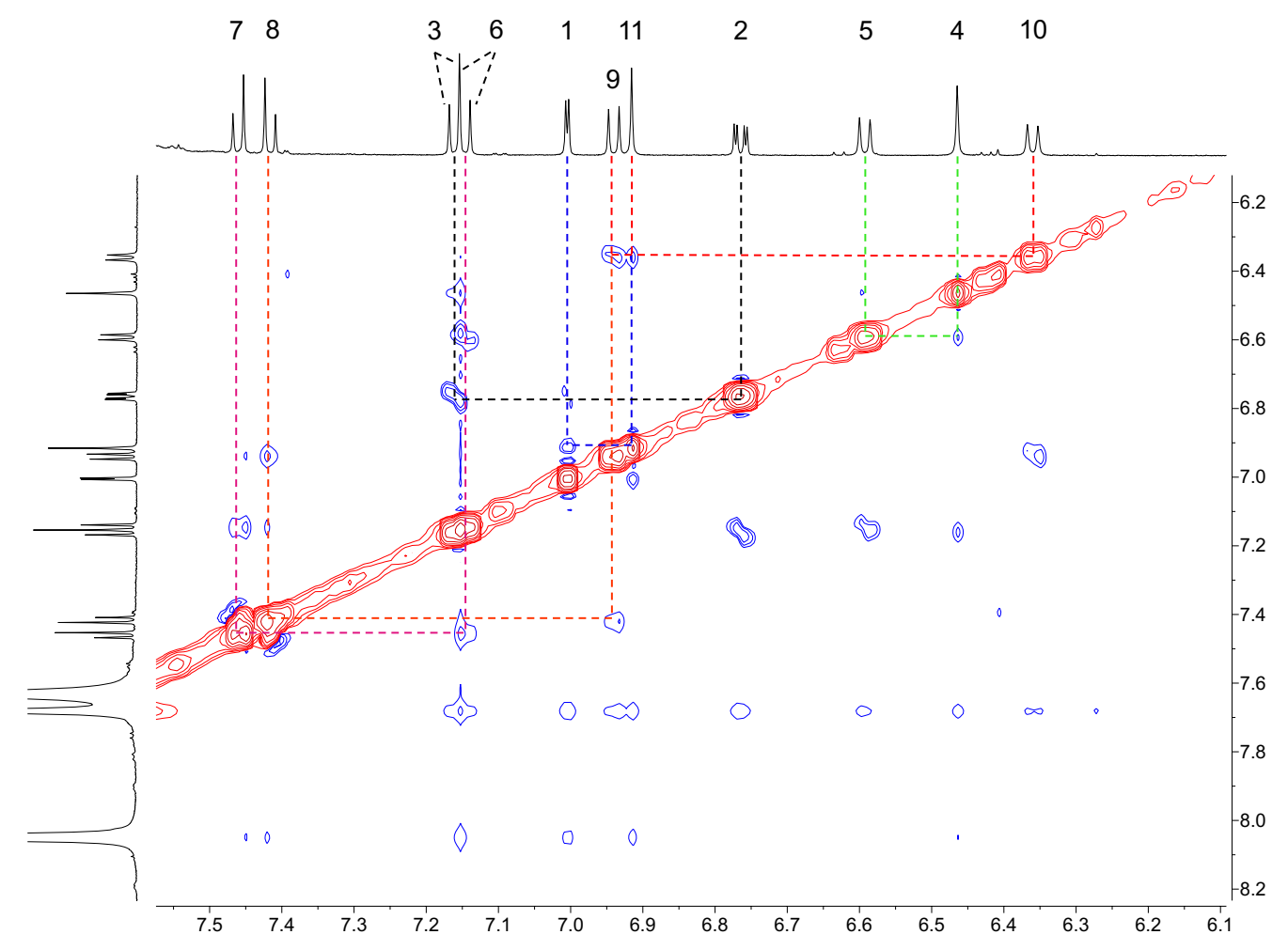

Fig. S14. ${ }^{1} \mathrm{H}-{ }^{1} \mathrm{H}$ ROESY NMR (600 MHz, $\mathrm{CD}_{3} \mathrm{CN}$, ppm) spectrum of iCor $\subset \mathbf{E x B o x}$. 

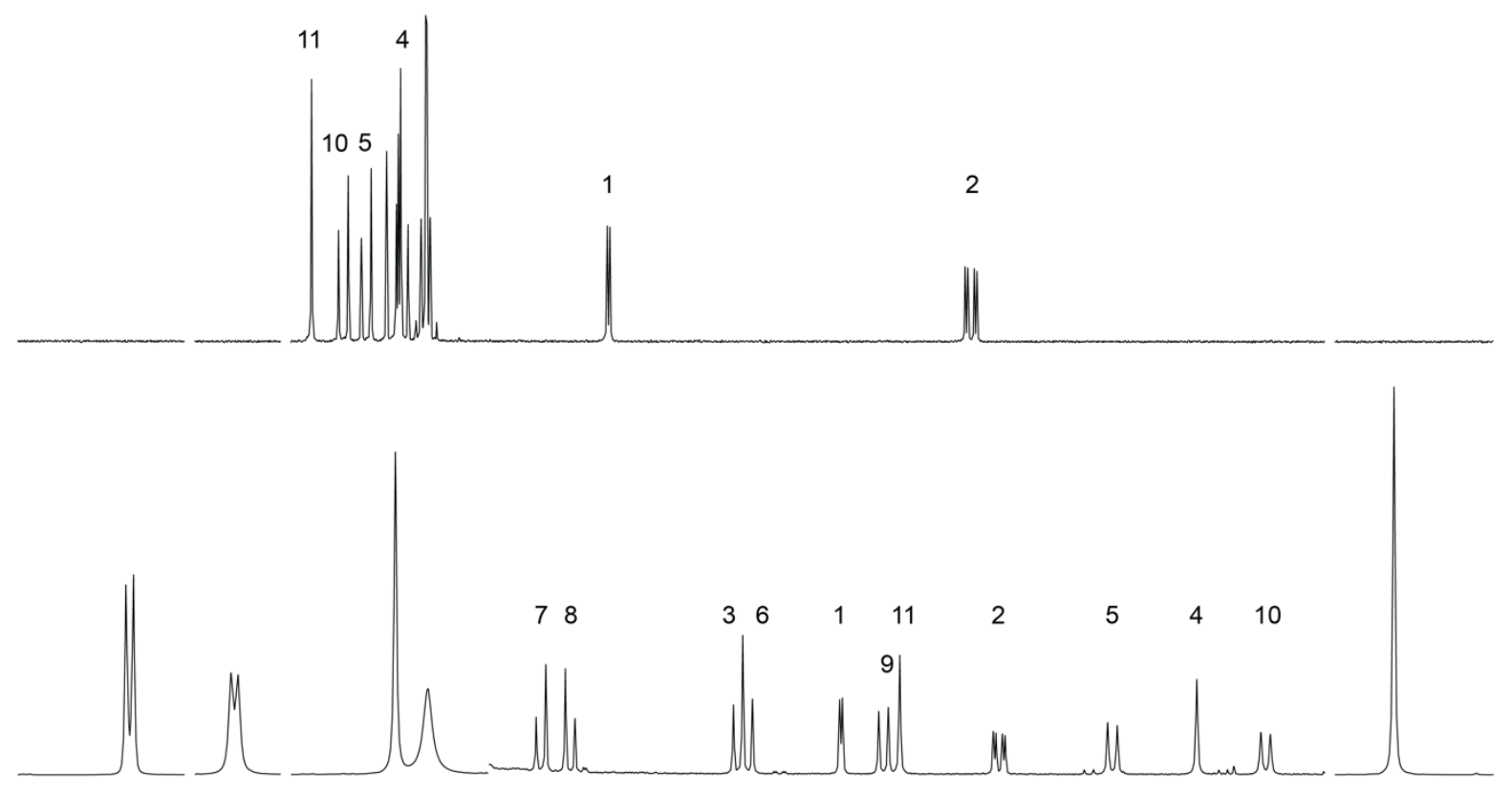

Fig. S15. Comparison of ${ }^{1} \mathrm{H} \mathrm{NMR}\left(600 \mathrm{MHz}, \mathrm{CD}_{3} \mathrm{CN}\right.$, ppm) spectra of iCor and iCorCExBox.

Table S3. Chemical shifts for bound and unbound iCor and the differences.

\begin{tabular}{|c|c|c|c|c|c|}
\hline $\begin{array}{l}\text { Label of } \\
\text { protons }\end{array}$ & $\begin{array}{l}\text { iCor } \\
(\mathrm{ppm})\end{array}$ & $\begin{array}{c}\text { iCor } \subset \mathbf{E x B o x} \\
(\mathrm{ppm})\end{array}$ & $\Delta \mathrm{ppm}$ & $\begin{array}{c}\text { iCor } \subset \text { ExCage } \\
(\mathrm{ppm})\end{array}$ & $\Delta \mathrm{ppm}$ \\
\hline 1 & 7.36 & 7.01 & 0.35 & N/A & $\mathrm{N} / \mathrm{A}$ \\
\hline 2 & 6.81 & 6.76 & 0.05 & 7.25 & 0.44 \\
\hline 3 & 7.63 & 7.16 & 0.47 & $\mathrm{~N} / \mathrm{A}$ & $\mathrm{N} / \mathrm{A}$ \\
\hline 4 & 7.67 & 6.46 & 1.21 & 7.21 & 0.46 \\
\hline 5 & 7.73 & 6.59 & 1.14 & $\mathrm{~N} / \mathrm{A}$ & $\mathrm{N} / \mathrm{A}$ \\
\hline 6 & 7.67 & 7.14 & 0.53 & $\mathrm{~N} / \mathrm{A}$ & N/A \\
\hline 7 & 7.64 & 7.46 & 0.18 & 7.35 & 0.29 \\
\hline 8 & 7.63 & 7.41 & 0.22 & 7.32 & 0.31 \\
\hline 9 & 7.68 & 6.94 & 1.29 & N/A & $\mathrm{N} / \mathrm{A}$ \\
\hline 10 & 7.76 & 6.36 & 1.40 & $\mathrm{~N} / \mathrm{A}$ & $\mathrm{N} / \mathrm{A}$ \\
\hline 11 & 7.81 & 6.92 & 0.89 & 7.39 & 0.42 \\
\hline
\end{tabular}


${ }^{1} \mathrm{H} \mathrm{NMR} / 500 \mathrm{MHz} / \mathrm{CD}_{3} \mathrm{CN} / 258 \mathrm{~K}$
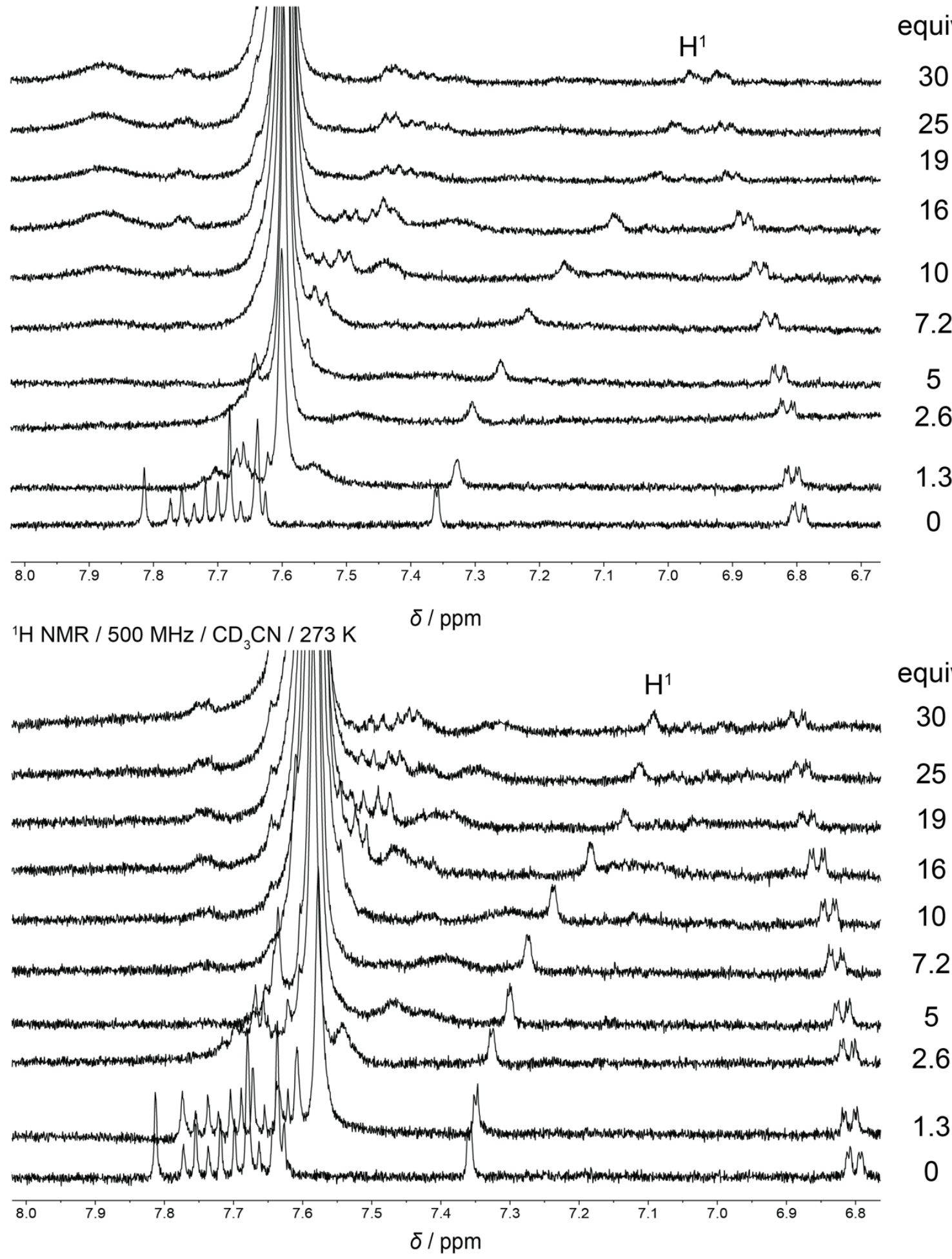

equiv.

Fig. S16. ${ }^{1} \mathrm{H}$ NMR titration. Stacked ${ }^{1} \mathrm{H}$ NMR spectra for the titration of a stock solution of iCor in $\mathrm{MeCN}_{-} d_{3}\left(1.41 \times 10^{-4} \mathrm{M}\right)$ with a solution of ExCage• $6 \mathrm{PF}_{6}$ dissolved in the stock solution of iCor in $\mathrm{MeCN}-d_{3}$ at $258 \mathrm{~K}$ (top) and $273 \mathrm{~K}$ (bottom). The concentration of ExCage varied from 0 to $4.23 \times 10^{-3} \mathrm{M}$. 
${ }^{1} \mathrm{H}$ NMR / $500 \mathrm{MHz} / \mathrm{CD}_{3} \mathrm{CN} / 293 \mathrm{~K}$
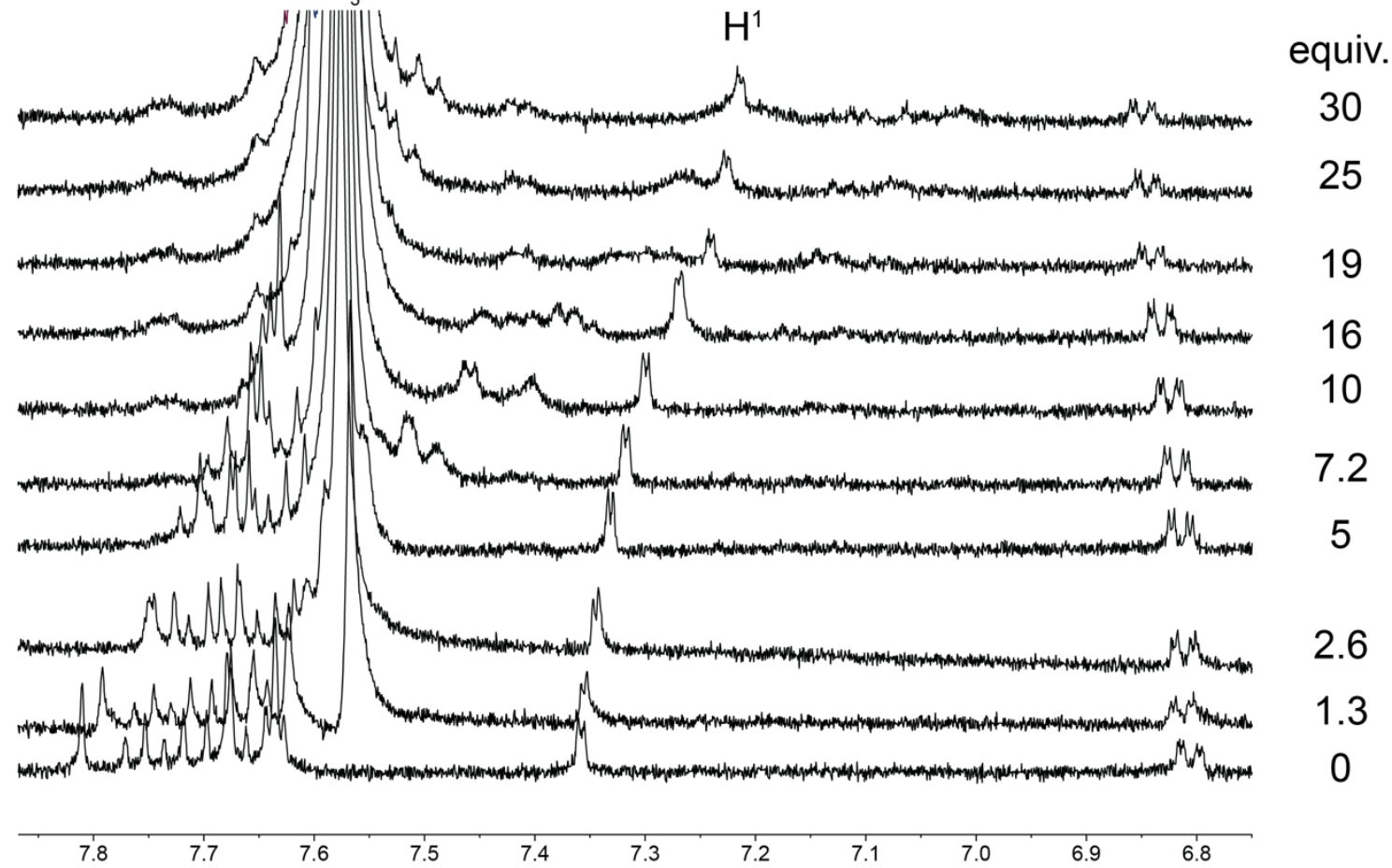

${ }^{1} \mathrm{H}$ NMR / $500 \mathrm{MHz} / \mathrm{CD}_{3} \mathrm{CN} / 313 \mathrm{~K}$

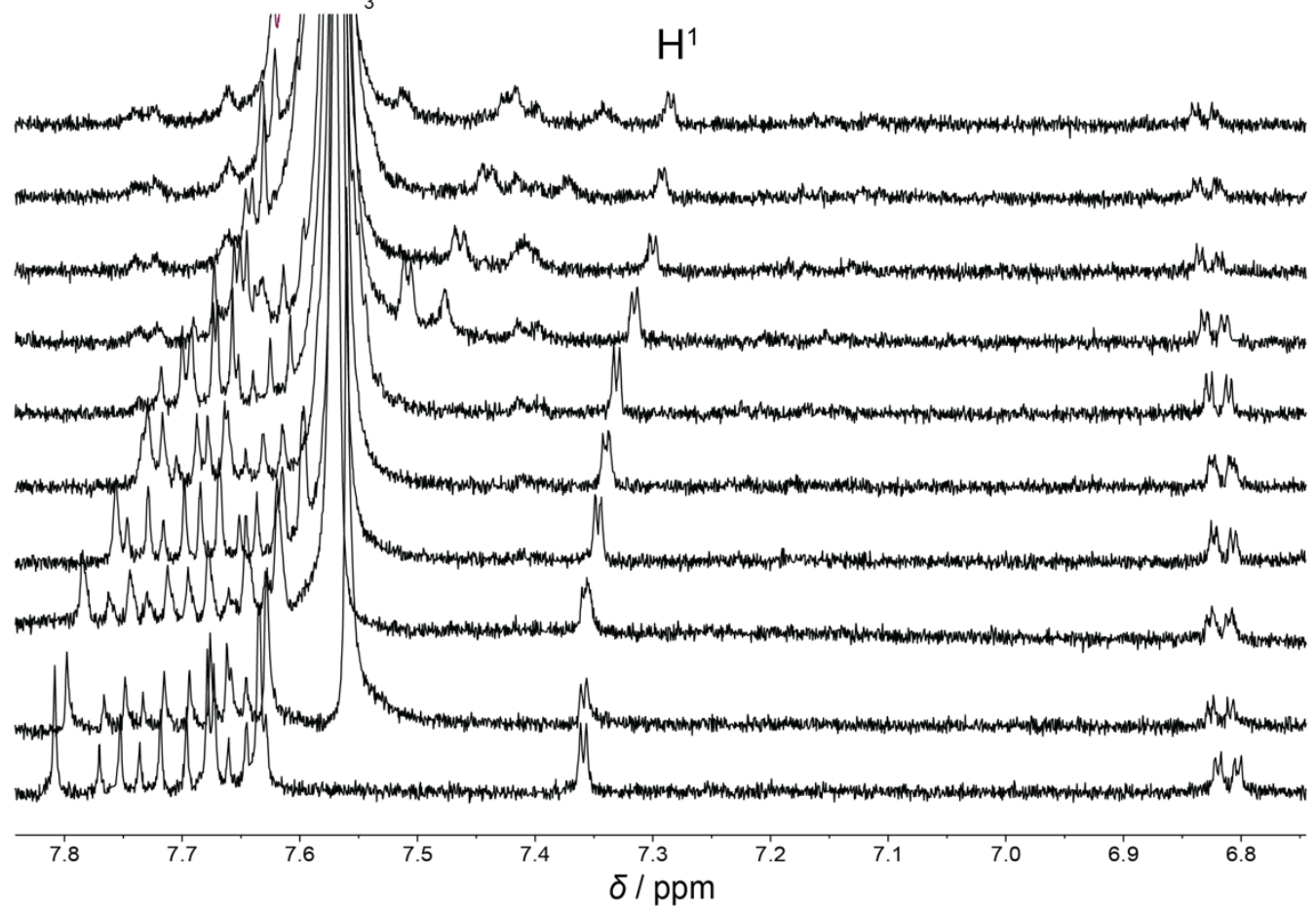

equiv.

30

25

19

Fig. S17. ${ }^{1} \mathrm{H}$ NMR titration. Stacked ${ }^{1} \mathrm{H}$ NMR spectra for the titration of a stock solution of iCor in $\mathrm{MeCN}_{-} d_{3}\left(1.41 \times 10^{-4} \mathrm{M}\right)$ with a solution of ExCage• $6 \mathrm{PF}_{6}$ dissolved in the stock solution of iCor in $\mathrm{MeCN}-d_{3}$ at $293 \mathrm{~K}$ (top) and $313 \mathrm{~K}$ (bottom). The concentration of ExCage varied from 0 to $4.23 \times 10^{-3} \mathrm{M}$. 


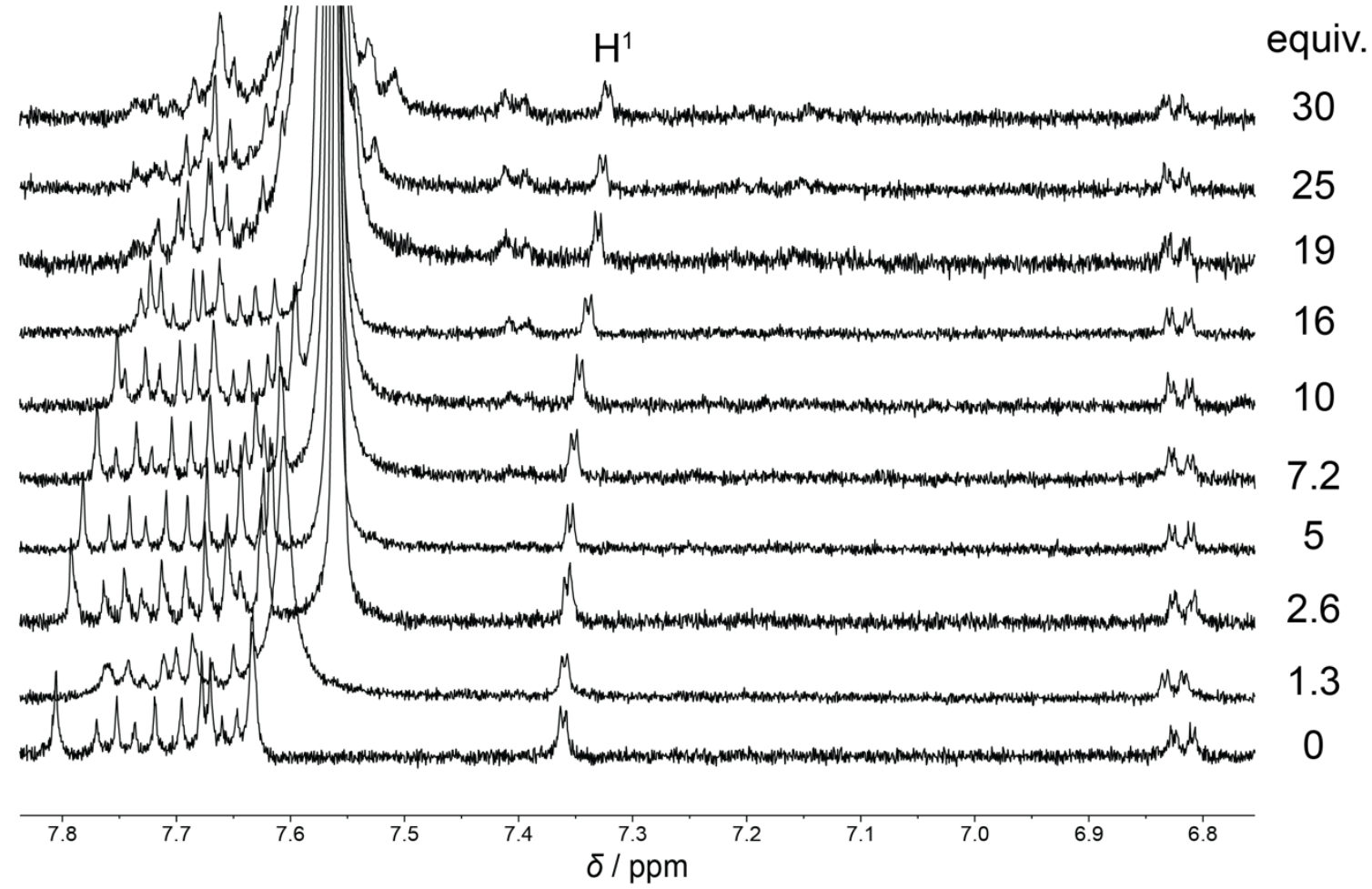

Fig. S18. ${ }^{1} \mathrm{H}$ NMR titration. Stacked ${ }^{1} \mathrm{H}$ NMR spectra for the titration of a stock solution of iCor in $\mathrm{MeCN}_{-} d_{3}\left(1.41 \times 10^{-4} \mathrm{M}\right)$ with a solution of ExCage $6 \mathrm{PF}_{6}$ dissolved in the stock solution of iCor in $\mathrm{MeCN}-d_{3}$ at $333 \mathrm{~K}$. The concentration of ExCage varied from 0 to $4.23 \times$ $10^{-3} \mathrm{M}$. 


\section{DynaFit Results}

Four independent titration measurements at $258 \mathrm{~K}$ fitted by DynaFit

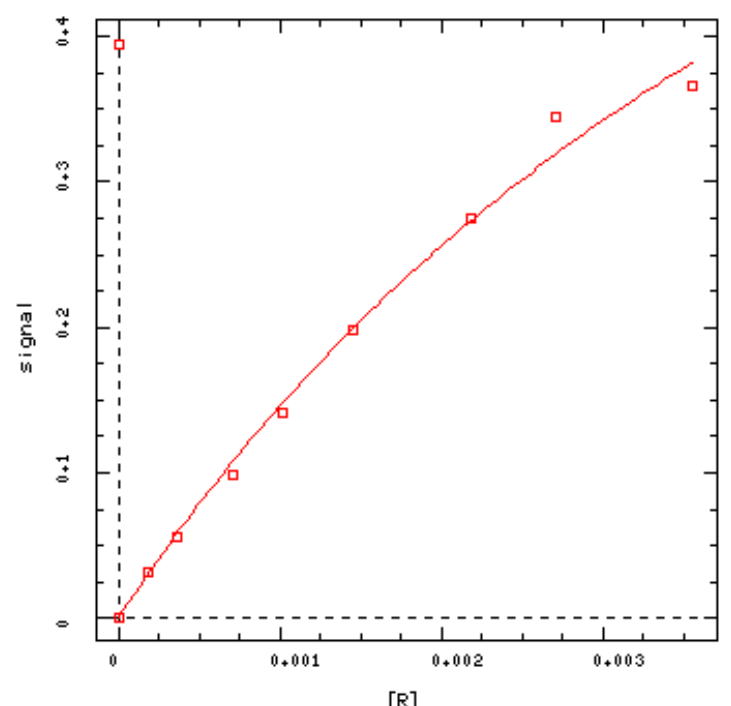

$K_{\mathrm{a}}=169 \mathrm{M}^{-1}$

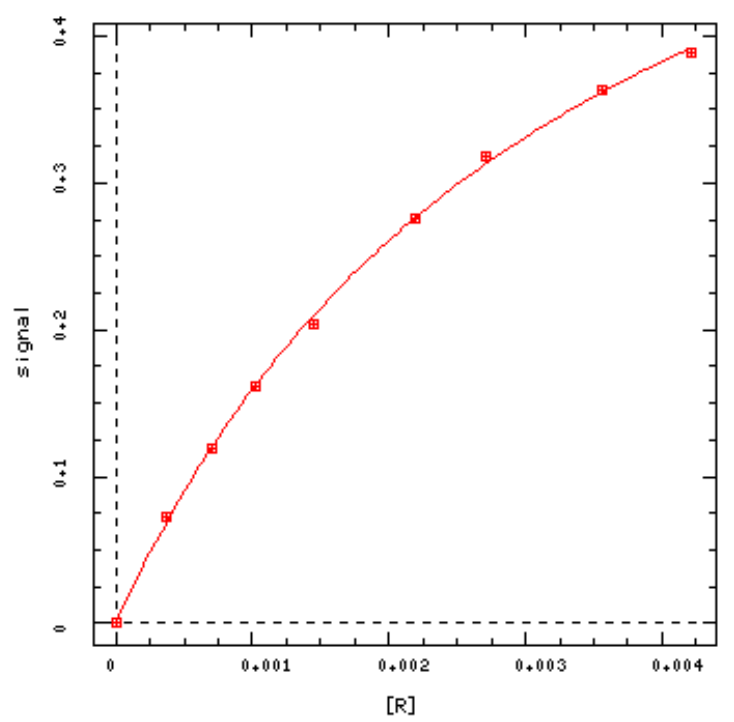

$K_{\mathrm{a}}=286 \mathrm{M}^{-1}$

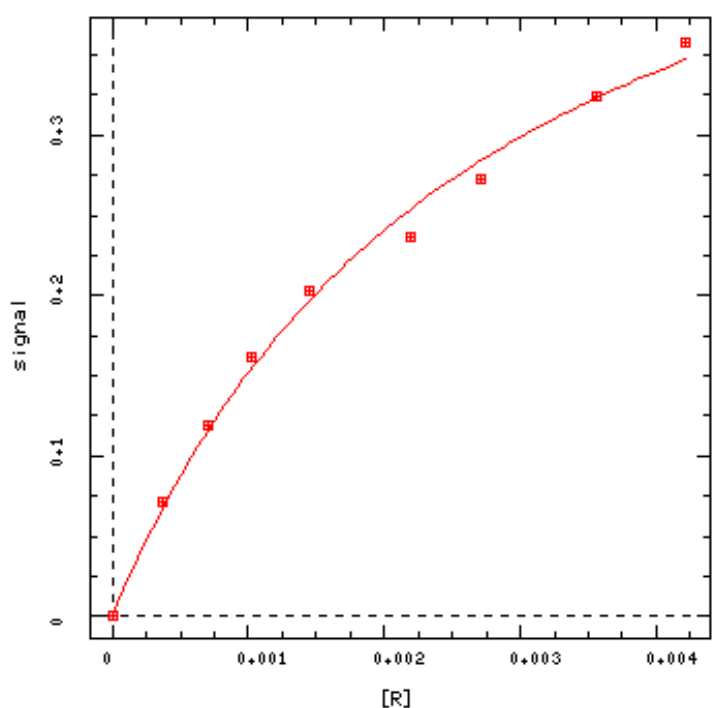

$K_{\mathrm{a}}=376 \mathrm{M}^{-1}$

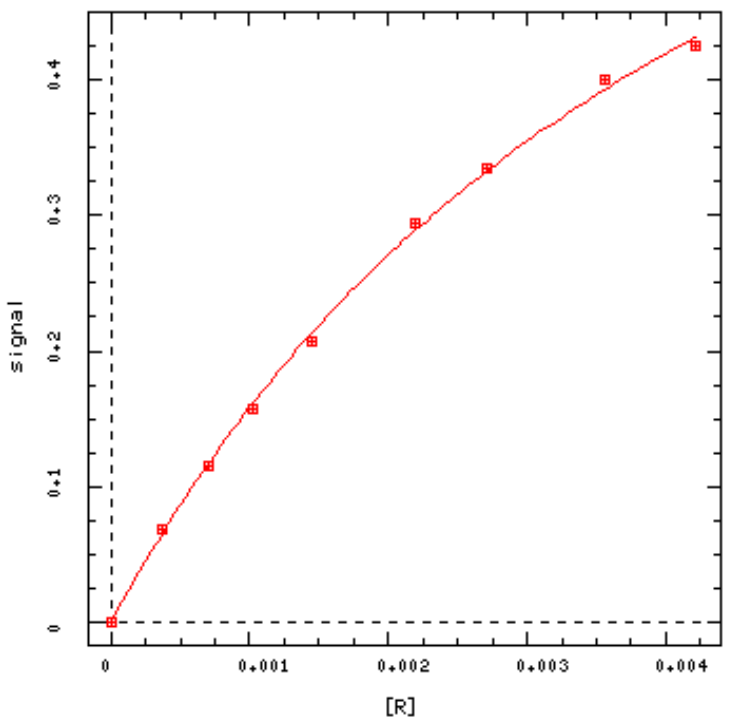

$K_{\mathrm{a}}=214 \mathrm{M}^{-1}$ 
Four independent titration measurements at $273 \mathrm{~K}$ fitted by DynaFit

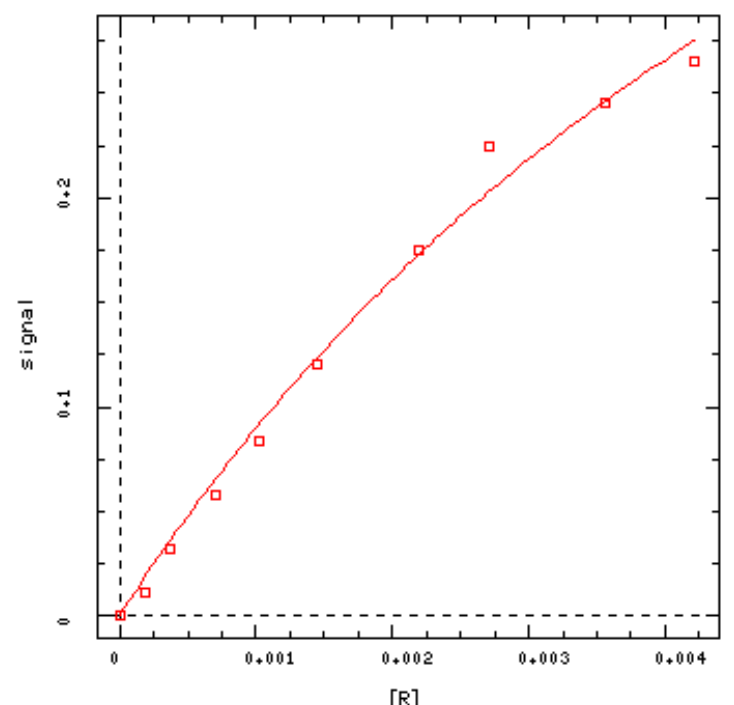

$K_{\mathrm{a}}=135 \mathrm{M}^{-1}$

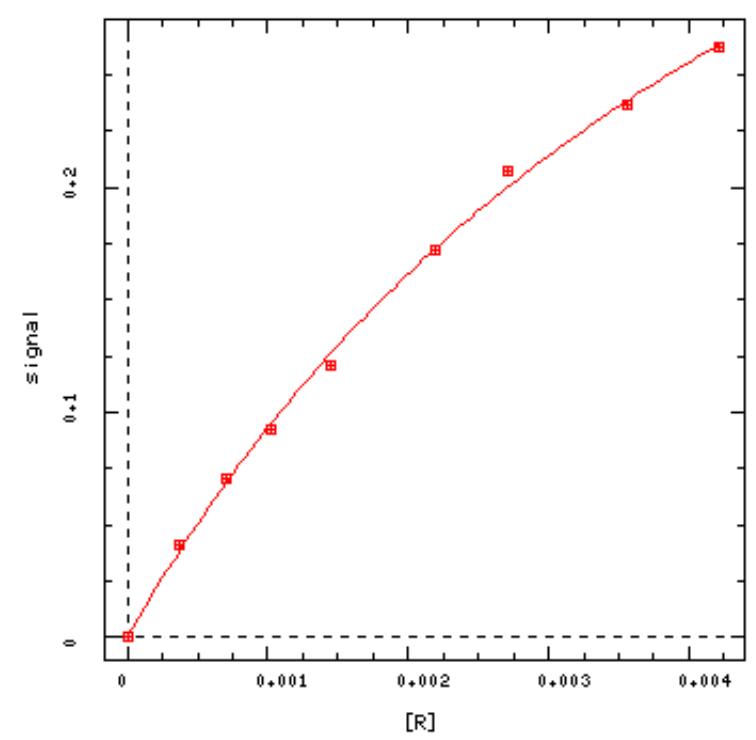

$K_{\mathrm{a}}=186 \mathrm{M}^{-1}$

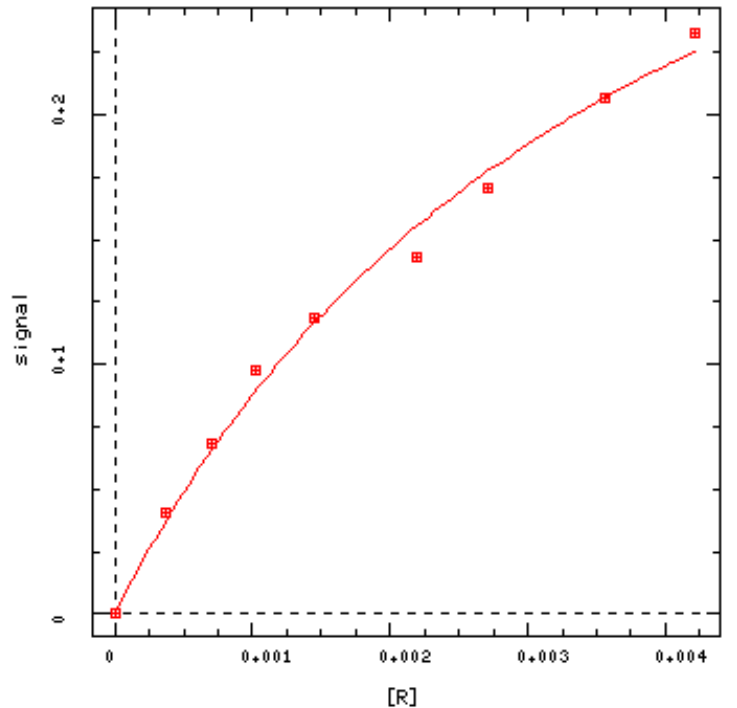

$K_{\mathrm{a}}=258 \mathrm{M}^{-1}$

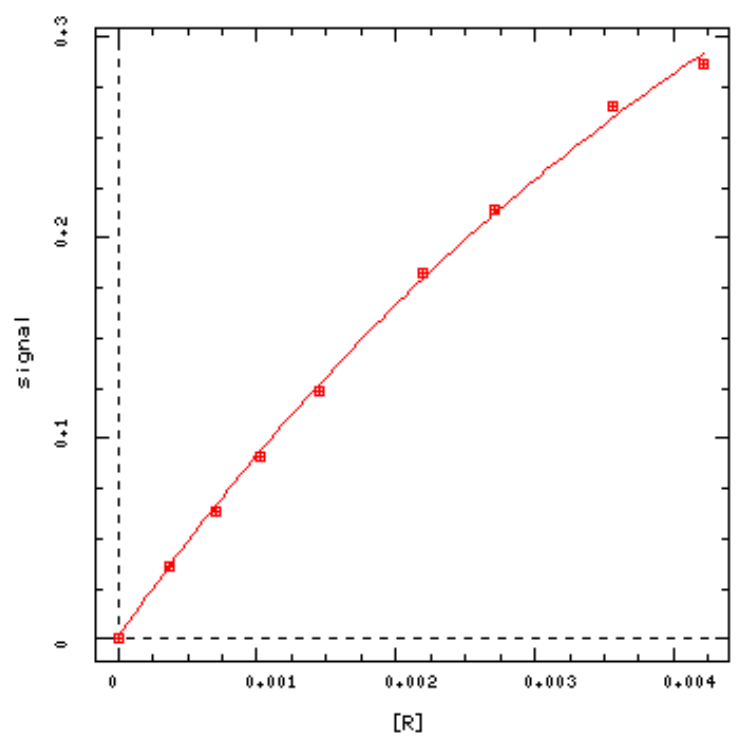

$K_{\mathrm{a}}=115 \mathrm{M}^{-1}$ 
Four independent titration measurements at $293 \mathrm{~K}$ fitted by DynaFit
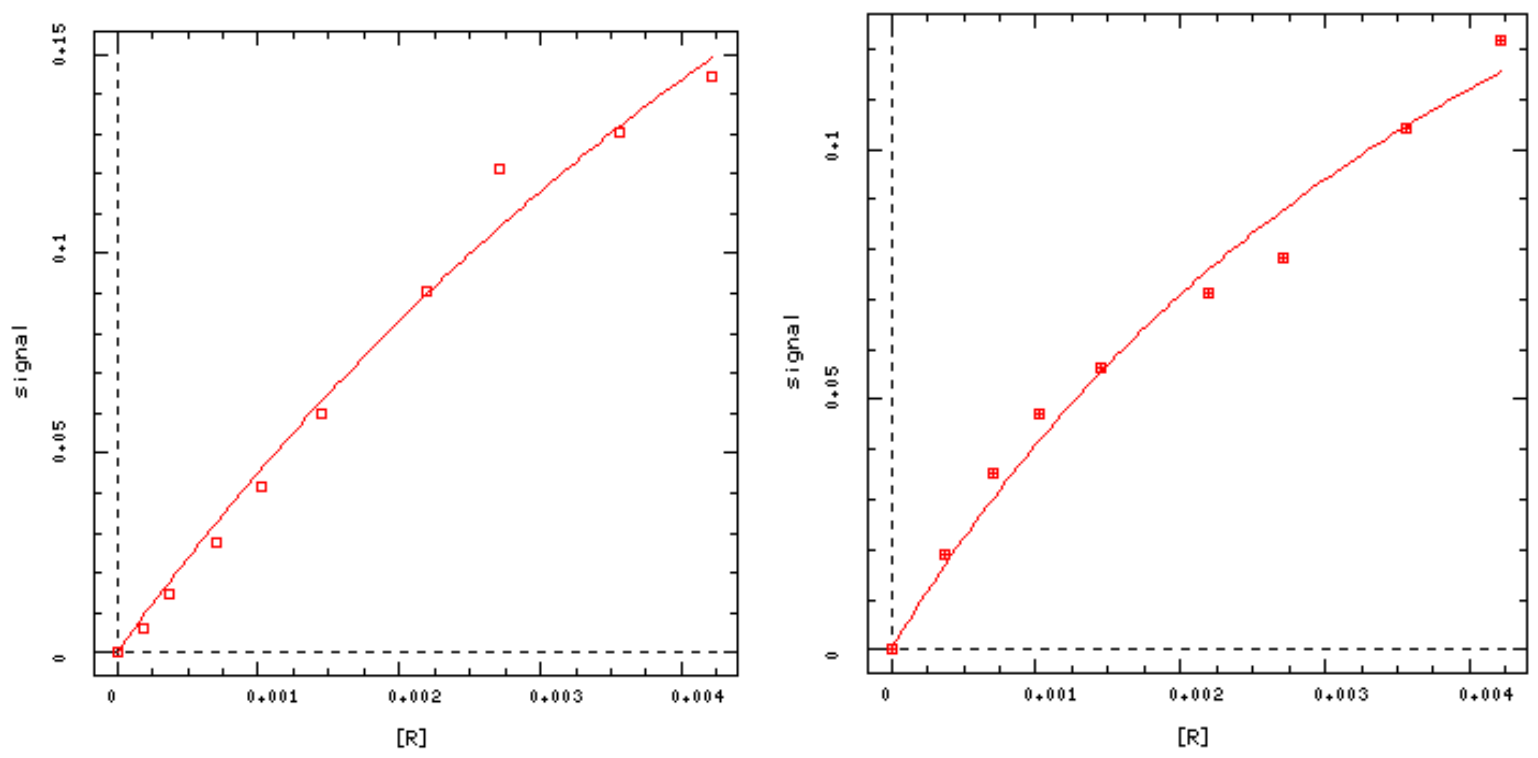

$$
K_{\mathrm{a}}=95 \mathrm{M}^{-1}
$$

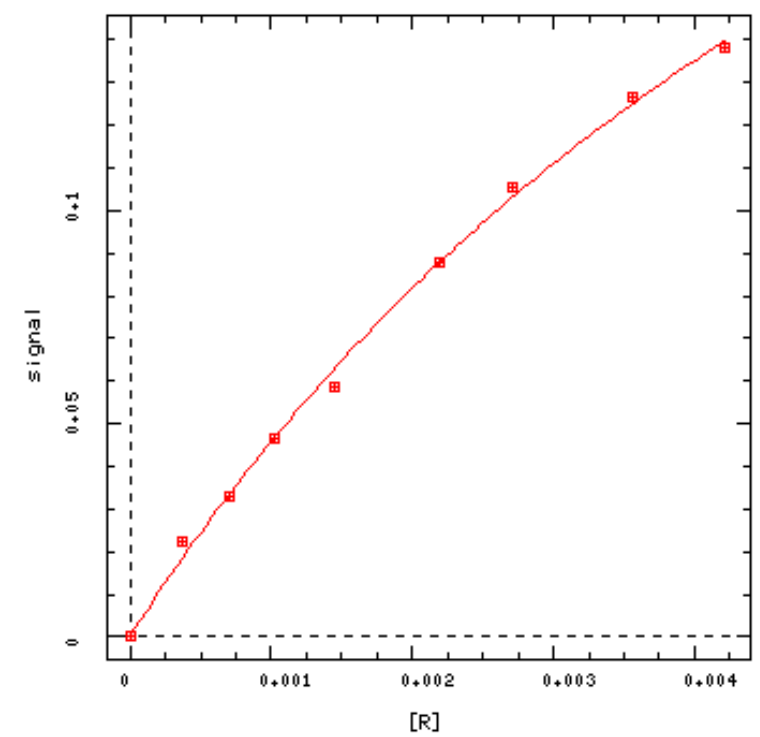

$$
K_{\mathrm{a}}=137 \mathrm{M}^{-1}
$$

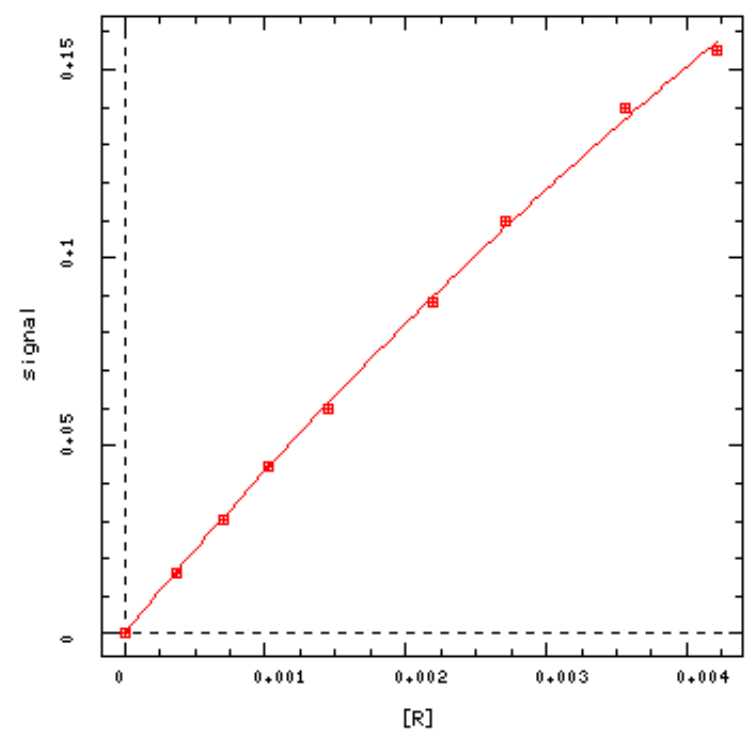

$$
K_{\mathrm{a}}=52 \mathrm{M}^{-1}
$$


Four independent titration measurements at $313 \mathrm{~K}$ fitted by DynaFit

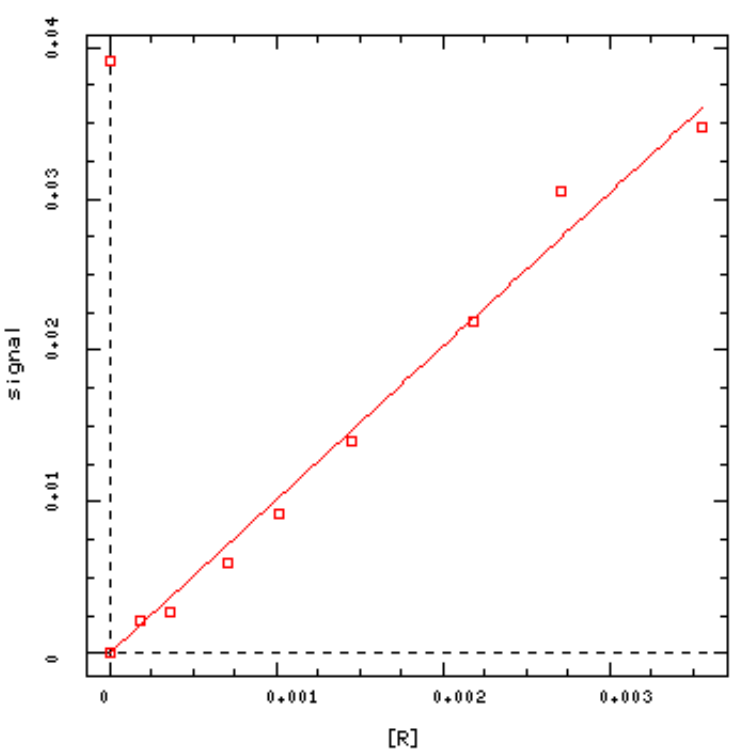

$$
K_{\mathrm{a}}=50 \mathrm{M}^{-1}
$$

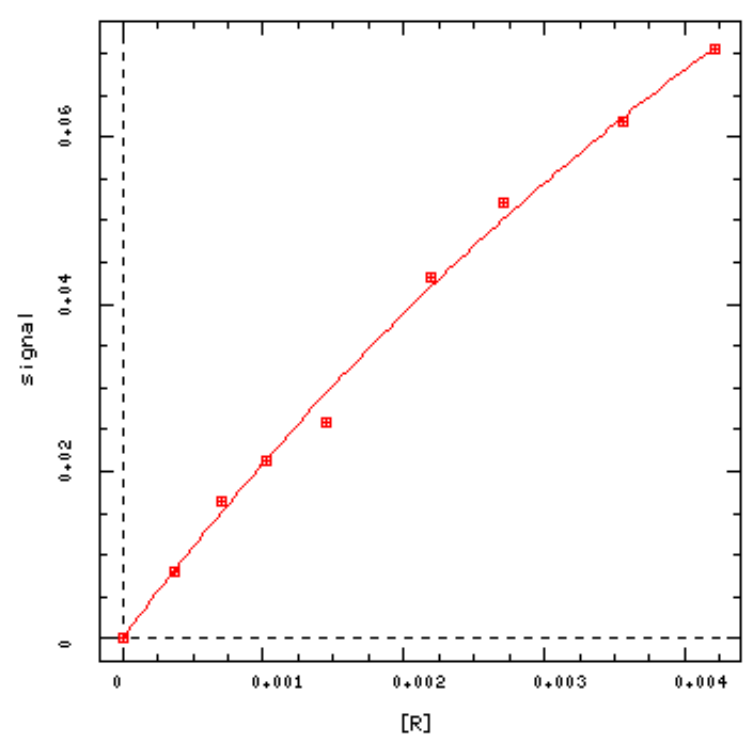

$K_{\mathrm{a}}=85 \mathrm{M}^{-1}$

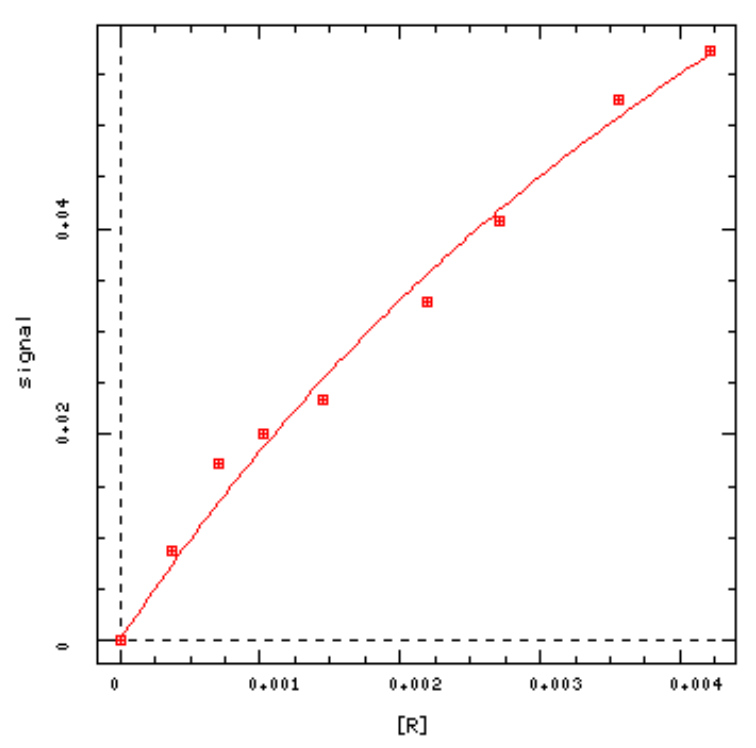

$$
K_{\mathrm{a}}=130 \mathrm{M}^{-1}
$$

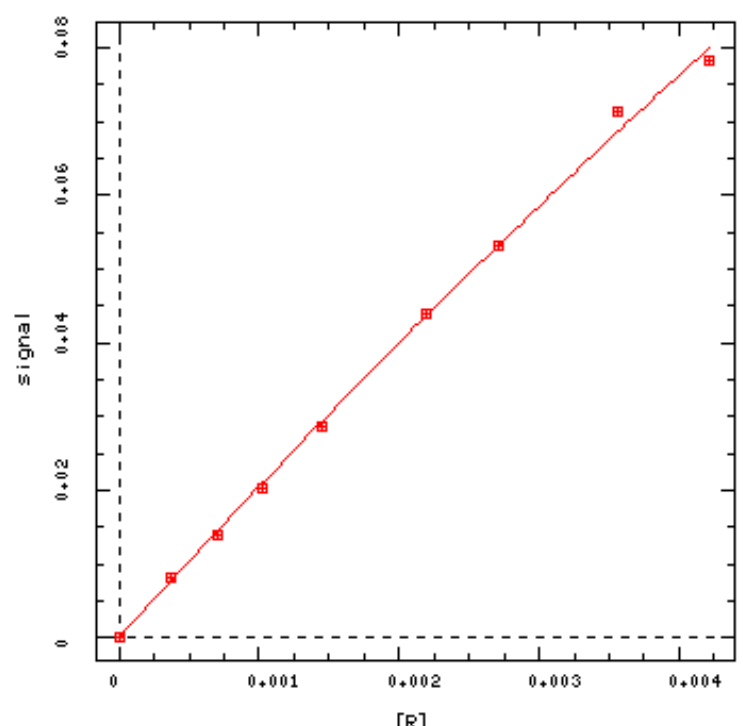

$$
K_{\mathrm{a}}=26 \mathrm{M}^{-1}
$$


Four independent titration measurements at $333 \mathrm{~K}$ fitted by DynaFit
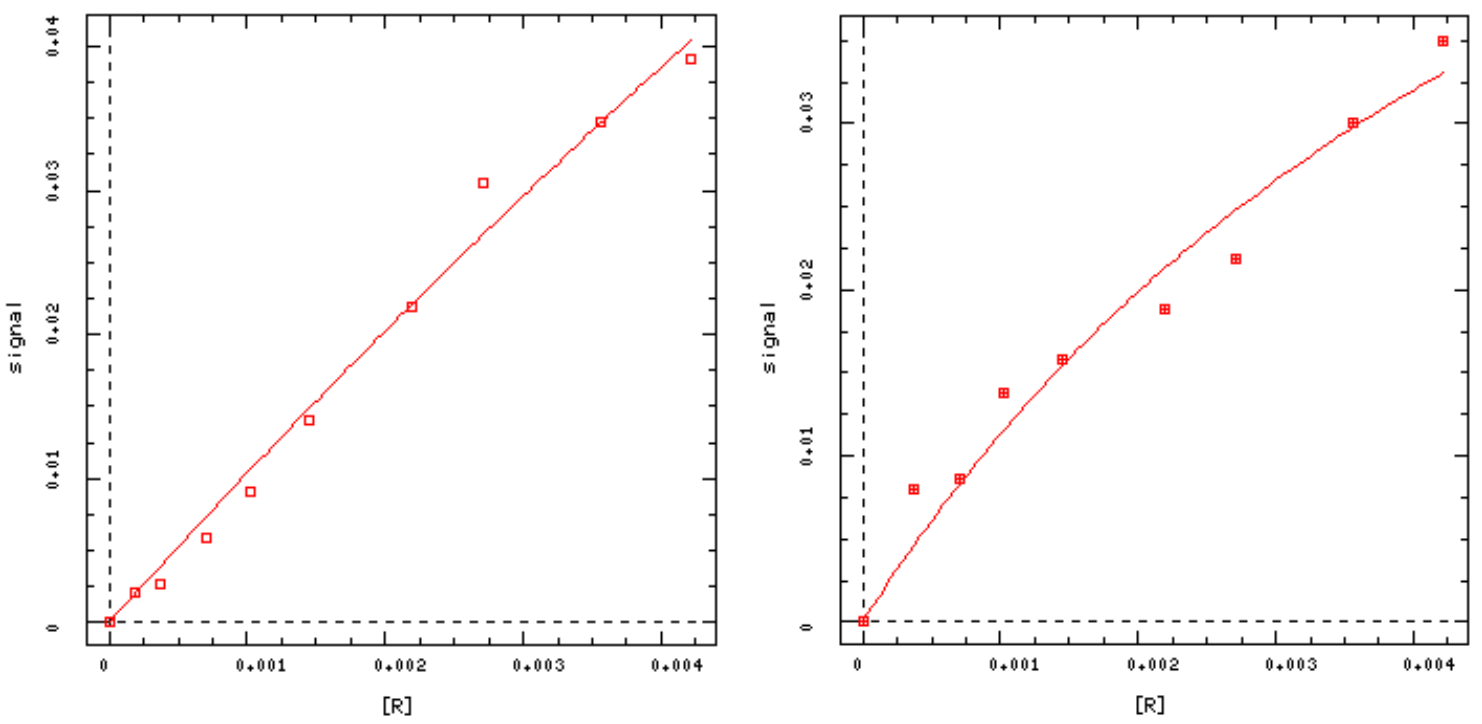

$K_{\mathrm{a}}=26 \mathrm{M}^{-1}$

$$
K_{\mathrm{a}}=164 \mathrm{M}^{-1}
$$
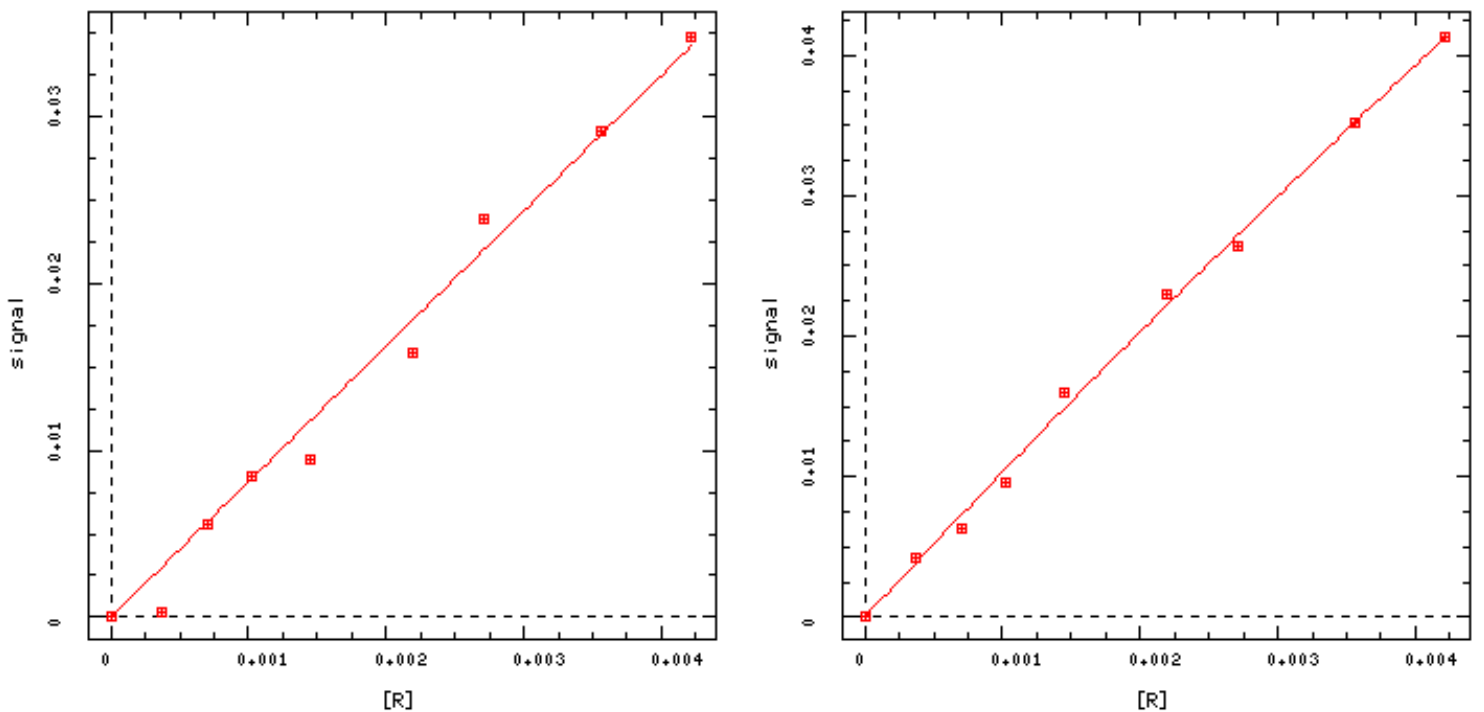

$K_{\mathrm{a}}=69 \mathrm{M}^{-1}$

$$
K_{\mathrm{a}}=17 \mathrm{M}^{-1}
$$




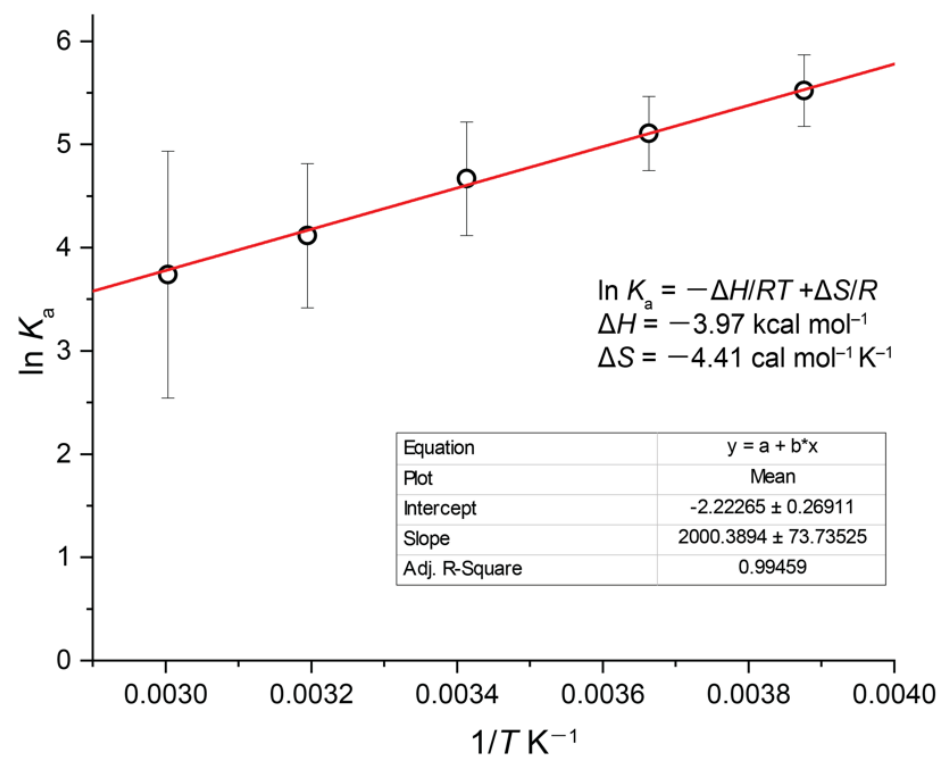

Fig. S19. Van't Hoff plot for iCor and ExCage. The $K_{\text {a }}$ values were determined by VT-NMR titrations (Figures S16-S18), where at each temperature, four independent titrations were carried out to obtain mean values and standard deviations. 

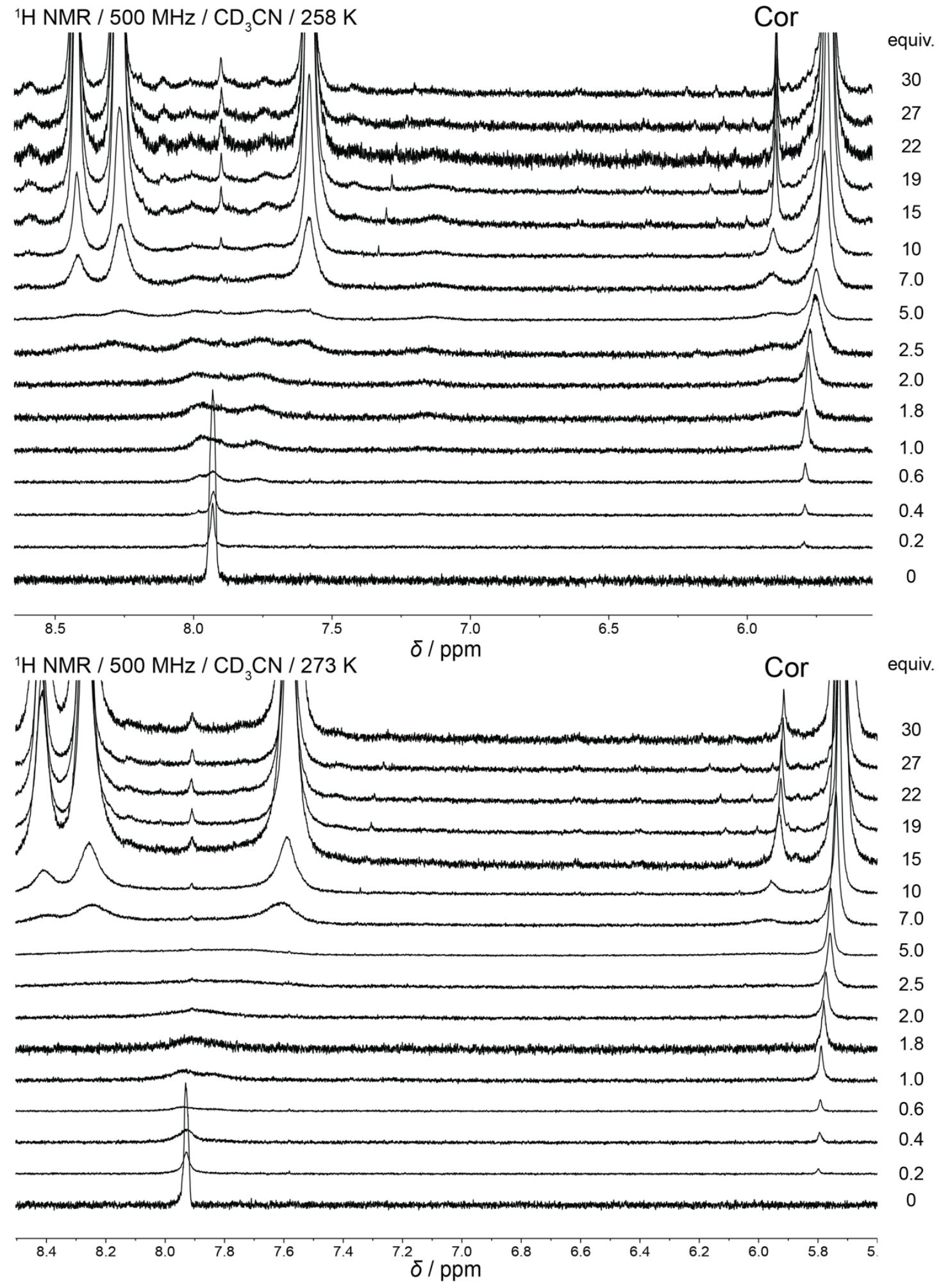

Fig. S20. ${ }^{1} \mathrm{H}$ NMR titration. Stacked ${ }^{1} \mathrm{H}$ NMR spectra for the titration of a stock solution of Cor in MeCN- $d_{3}\left(1.41 \times 10^{-4} \mathrm{M}\right)$ with a solution of ExCage $\bullet 6 \mathrm{PF}_{6}$ dissolved in the stock solution of Cor in $\mathrm{MeCN}-d_{3}$ at $258 \mathrm{~K}$ (top) and $273 \mathrm{~K}$ (bottom). The concentration of ExCage varied from 0 to $4.23 \times 10^{-3} \mathrm{M}$. These data were not used to calculate $K_{\mathrm{a}}$ because the Cor signals from 1 to 7 equivalents are too broad and the difference in chemical shifts of Cor from 7 to 30 equivalents is too small. 

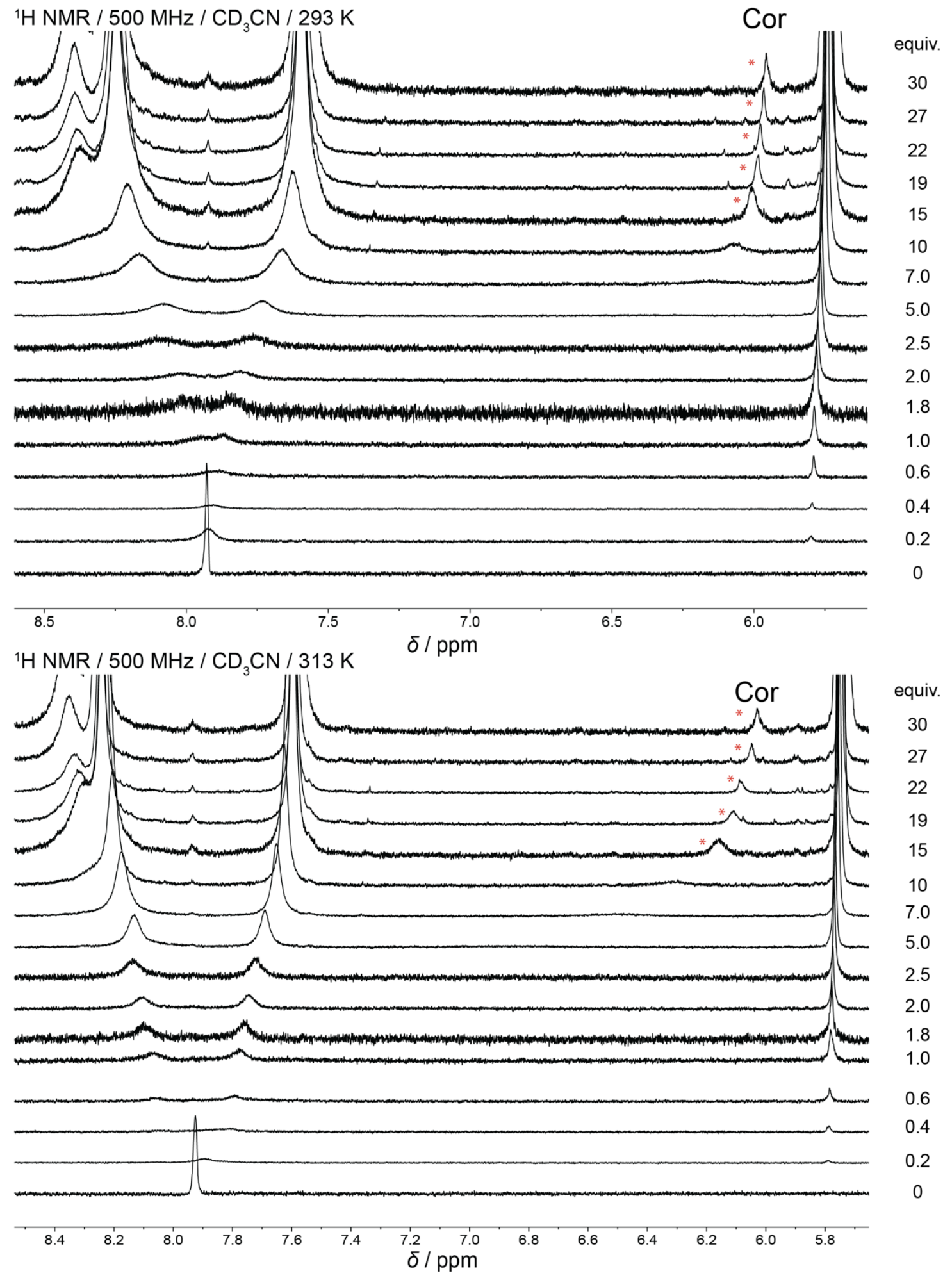

Fig. S21. ${ }^{1} \mathrm{H}$ NMR titration. Stacked ${ }^{1} \mathrm{H}$ NMR spectra for the titration of a stock solution of iCor in $\mathrm{MeCN}_{-} d_{3}\left(1.41 \times 10^{-4} \mathrm{M}\right)$ with a solution of ExCage $6 \mathrm{PF}_{6}$ dissolved in the stock solution of Cor in $\mathrm{MeCN}_{-} d_{3}$ at $293 \mathrm{~K}$ (top) and $313 \mathrm{~K}$ (bottom). The concentration of ExCage varied from 0 to $4.23 \times 10^{-3} \mathrm{M}$. 


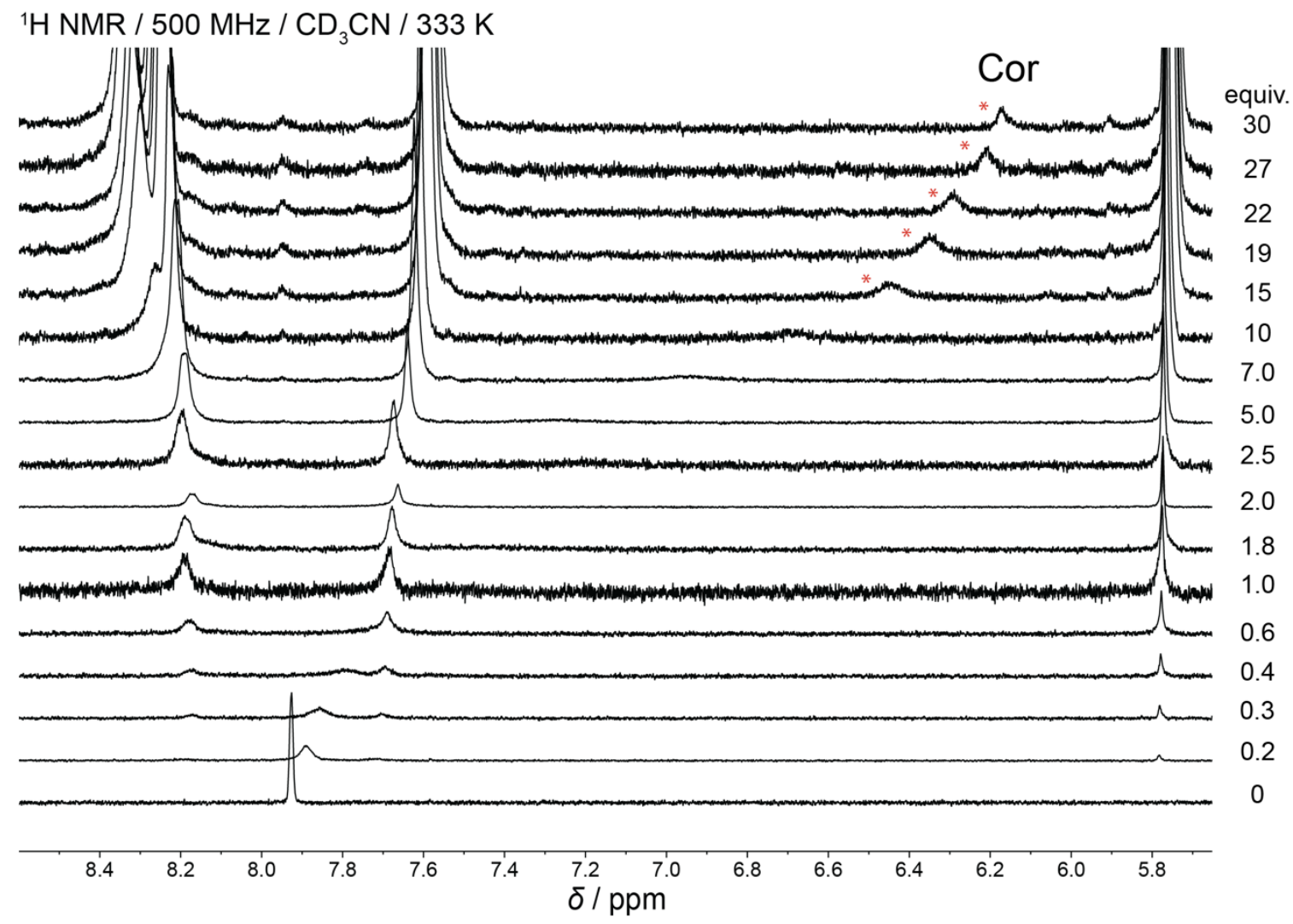

Fig. S22. ${ }^{1} \mathbf{H}$ NMR titration. Stacked ${ }^{1} \mathrm{H}$ NMR spectra for the titration of a stock solution of iCor in MeCN- $d_{3}\left(1.41 \times 10^{-4} \mathrm{M}\right)$ with a solution of ExCage•6PF 6 dissolved in the stock solution of $\mathbf{C o r}$ in $\mathrm{MeCN}-d_{3}$ at $333 \mathrm{~K}$. The concentration of ExCage varied from 0 to $4.23 \times$ $10^{-3} \mathrm{M}$.

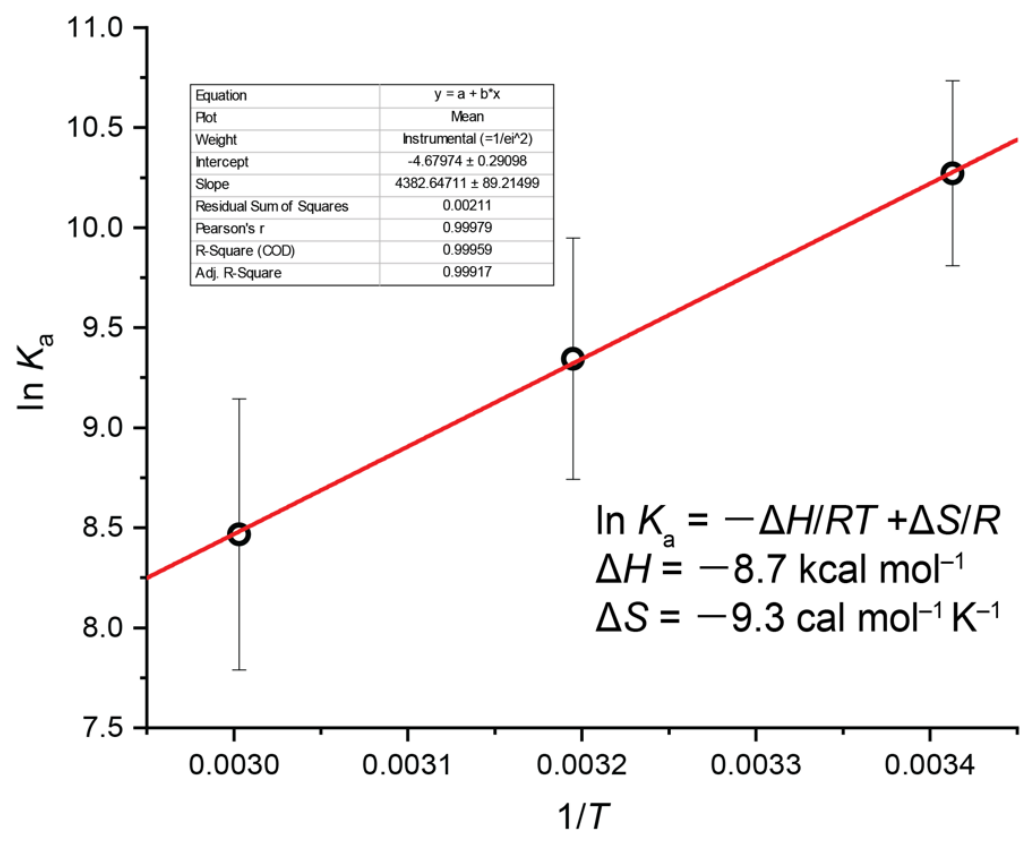

Fig. S23. Van't Hoff plot for Cor and ExCage. The $K_{\mathrm{a}}$ values were determined by VT-NMR titrations (Figures S21-S22), where at each temperature, four titration points (marked with *) from one titration were used to obtain mean values and standard deviations $\left(K_{\mathrm{a}}=(3.1 \pm 1.6) \times\right.$ $10^{4} \mathrm{M}^{-1}(293 \mathrm{~K}),(1.3 \pm 0.91) \times 10^{4} \mathrm{M}^{-1}(313 \mathrm{~K})$, and $\left.(5.7 \pm 4.5) \times 10^{3} \mathrm{M}^{-1}(333 \mathrm{~K})\right)$. 


\section{S4. Circular dichroism time-course measurements}

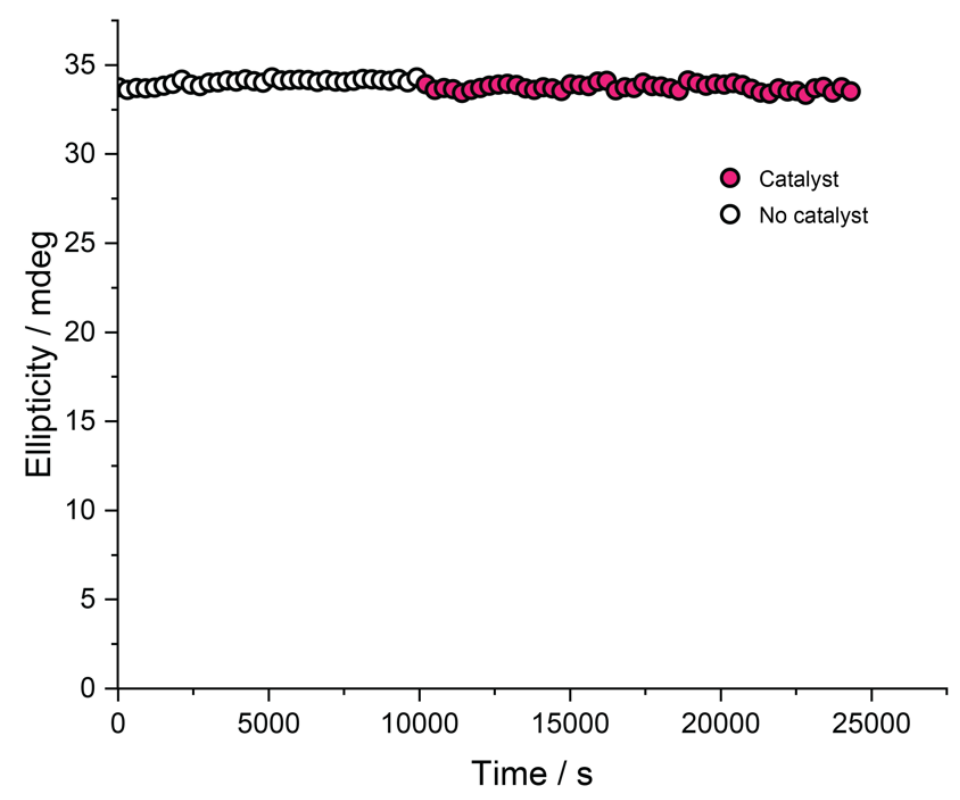

Fig. S24. Racemization of iCor with 5 equiv of ExBox. CD time-course measurement for iCor in $\mathrm{MeCN}\left(1.1 \times 10^{-4} \mathrm{M}\right)$ at $40^{\circ} \mathrm{C}$ before (white) and after (pink) the addition of catalyst $\left(5.5 \times 10^{-4} \mathrm{M}\right)$.

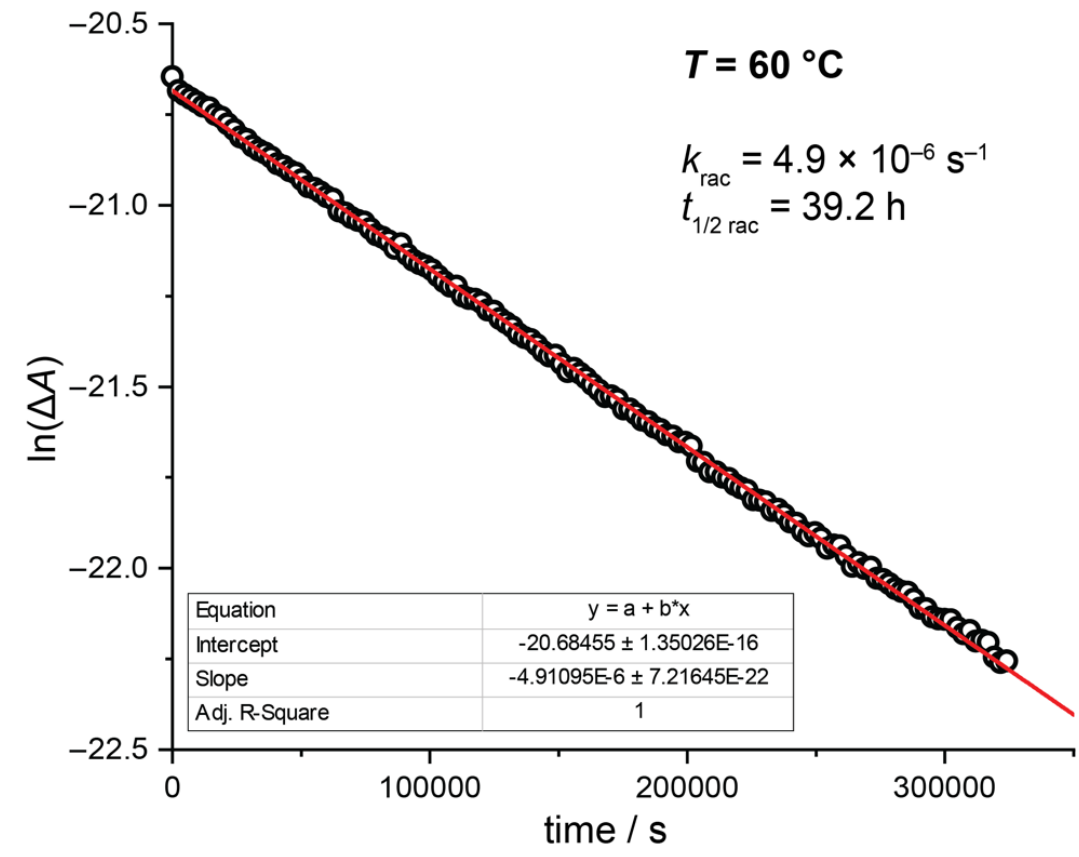

Fig. S25. Racemization of iCor. CD time-course measurement of iCor in MeCN $\left(1.1 \times 10^{-4}\right.$ M) at $60{ }^{\circ} \mathrm{C}$. Data from 0 to $\sim 300000 \mathrm{~s}$ were used for linear fit. 


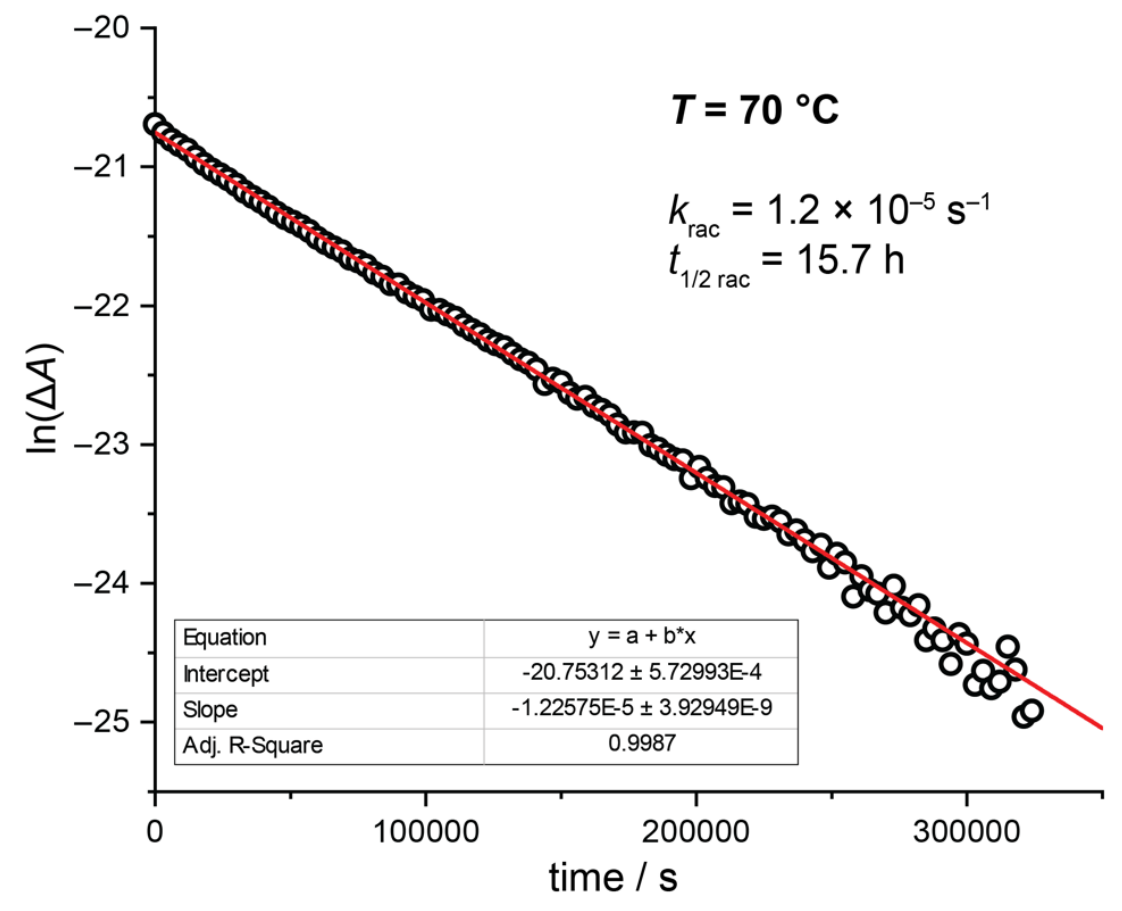

Fig. S26. Racemization of iCor. CD time-course measurement of iCor in MeCN $\left(1.1 \times 10^{-4}\right.$ $\mathrm{M})$ at $70{ }^{\circ} \mathrm{C}$. Data from 0 to $\sim 200000 \mathrm{~s}$ were used for linear fit.

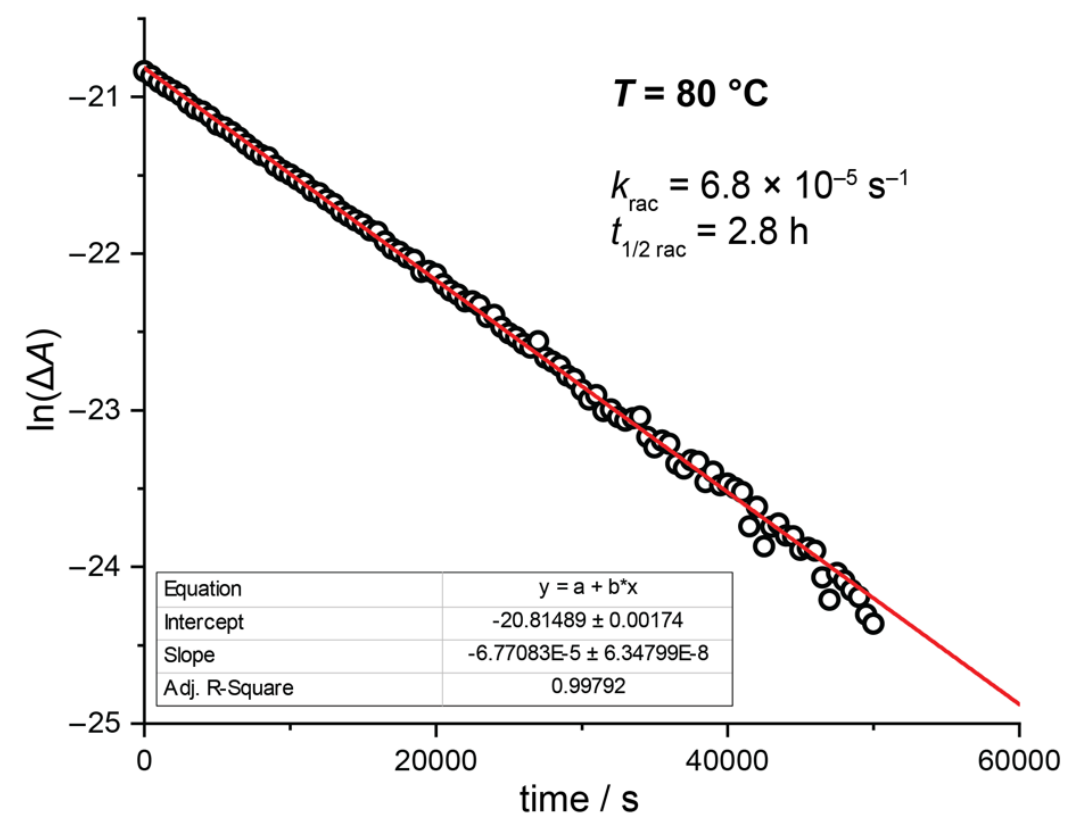

Fig. S27. Racemization of iCor. CD time-course measurement of iCor in MeCN $\left(1.1 \times 10^{-4}\right.$ $\mathrm{M})$ at $80{ }^{\circ} \mathrm{C}$. Data from 0 to $\sim 30000 \mathrm{~s}$ were used for linear fit. 


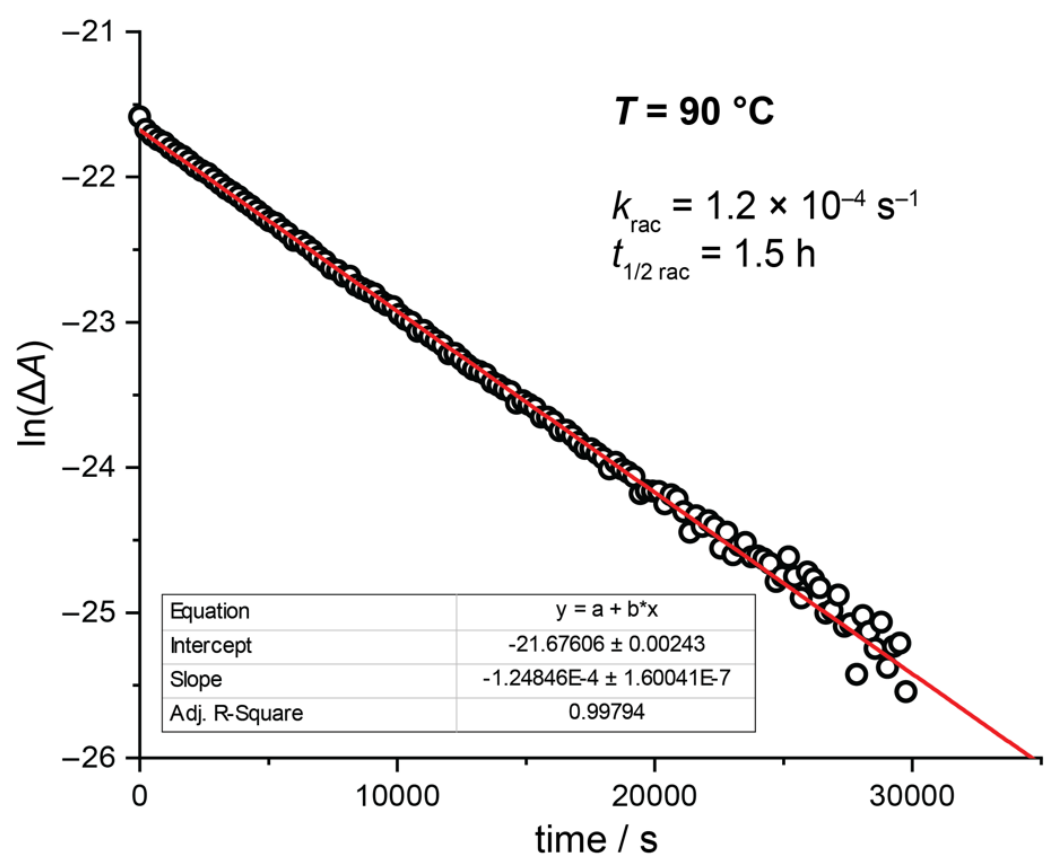

Fig. S28. Racemization of iCor. CD time-course measurement of iCor in MeCN $\left(1.1 \times 10^{-4}\right.$ $\mathrm{M})$ at $90^{\circ} \mathrm{C}$. Data from 0 to $\sim 15000 \mathrm{~s}$ were used for linear fit.

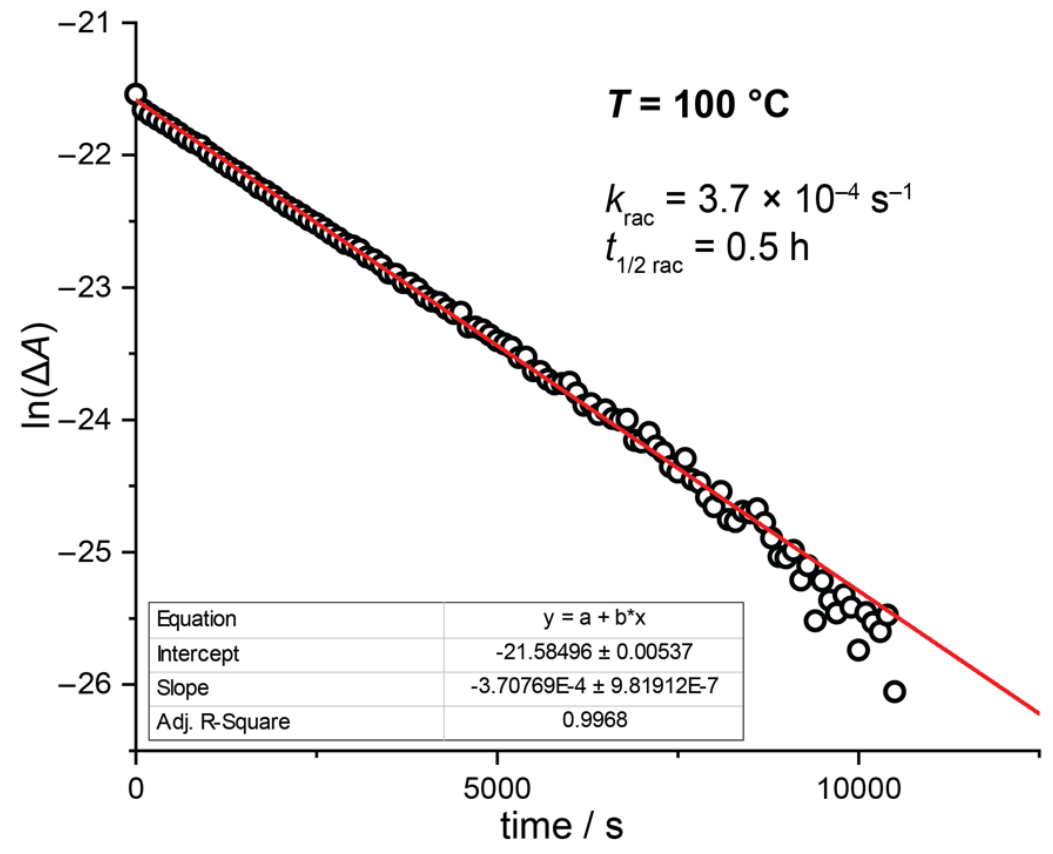

Fig. S29. Racemization of iCor. CD time-course measurement of iCor in $\mathrm{MeCN}\left(1.1 \times 10^{-4}\right.$ $\mathrm{M})$ at $100{ }^{\circ} \mathrm{C}$. Data from 0 to $\sim 5000 \mathrm{~s}$ were used for linear fit. 


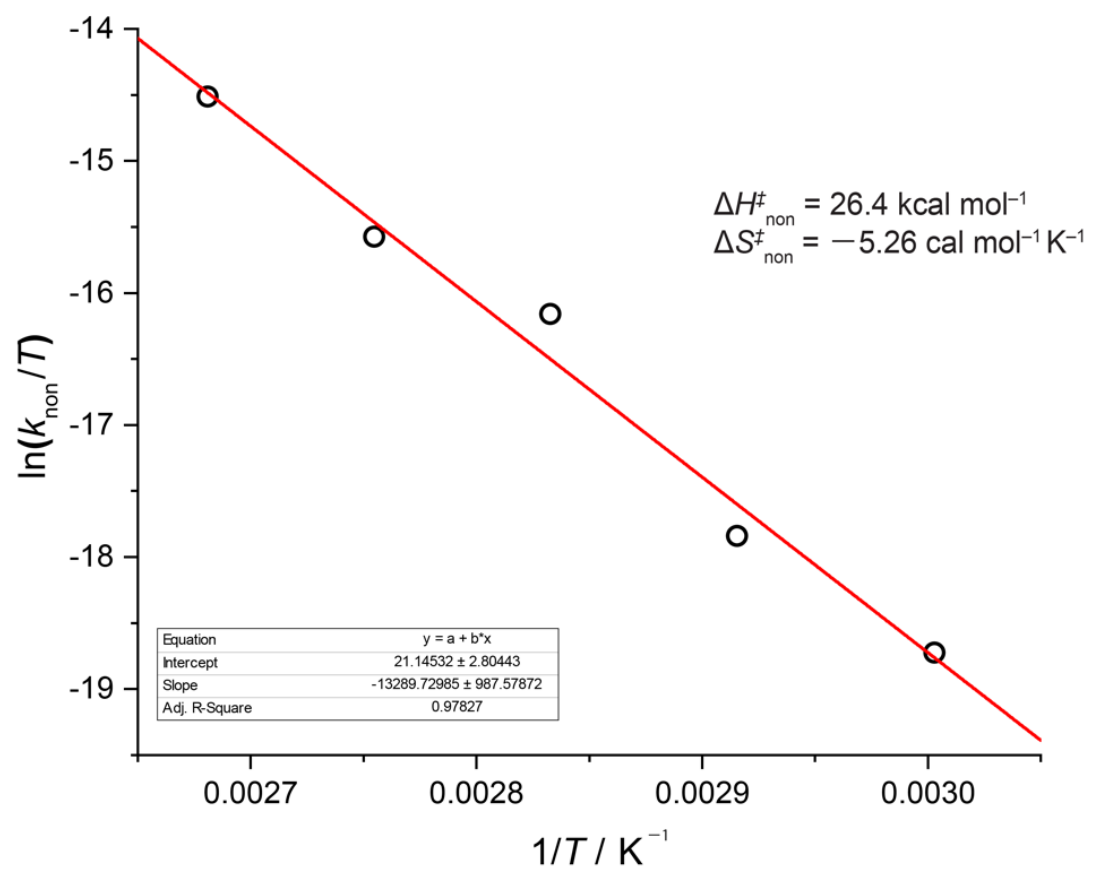

Fig. S30. Eyring plot. Enantiomerization of iCor in MeCN. The $k_{\text {non }}$ values were obtained from the $k_{\text {rac }}$ values $\left(k_{\text {non }}=k_{\text {rac }} / 2\right)$ reported in Figures S25-S29.

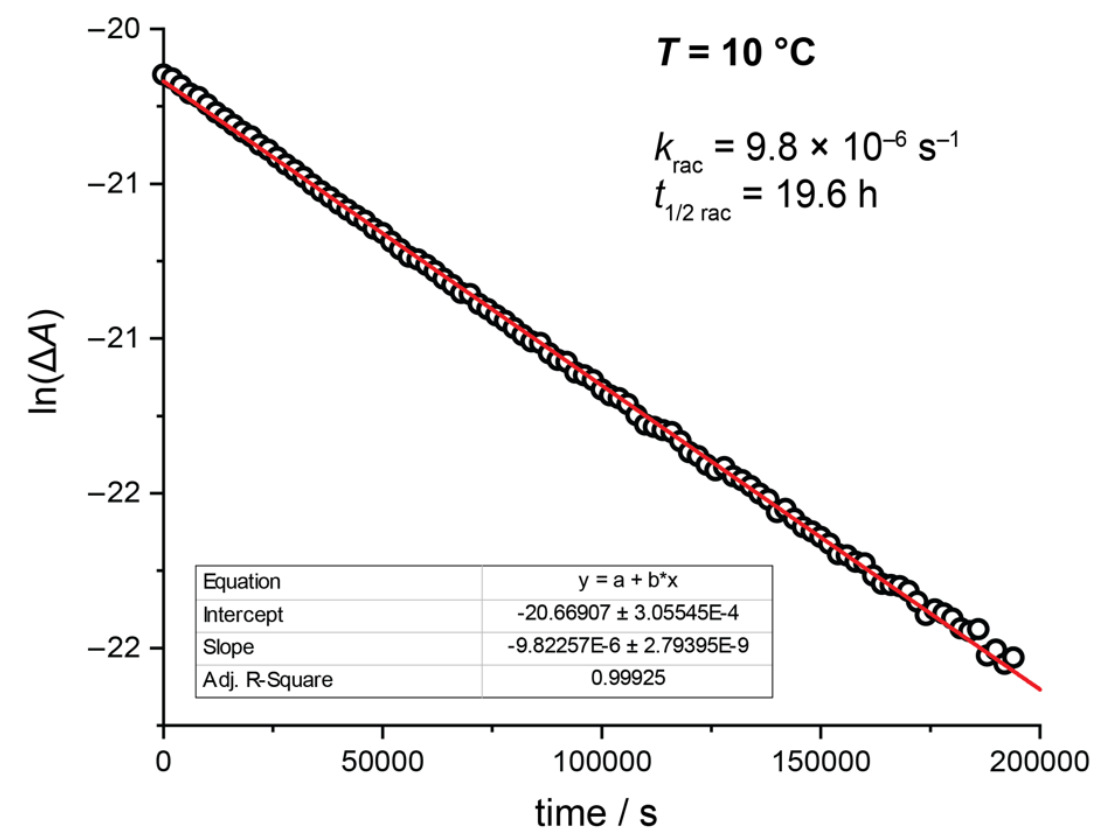

Fig. S31. Racemization of iCor with 5 equiv of ExCage. CD time-course measurement for iCor $\left(1.1 \times 10^{-4} \mathrm{M}\right)$ with 5 equiv of ExCage•6PF $6\left(5.5 \times 10^{-4} \mathrm{M}\right)$ in $\mathrm{MeCN}$ at $10^{\circ} \mathrm{C}$. Data from 0 to $\sim 150000 \mathrm{~s}$ were used for linear fit. 


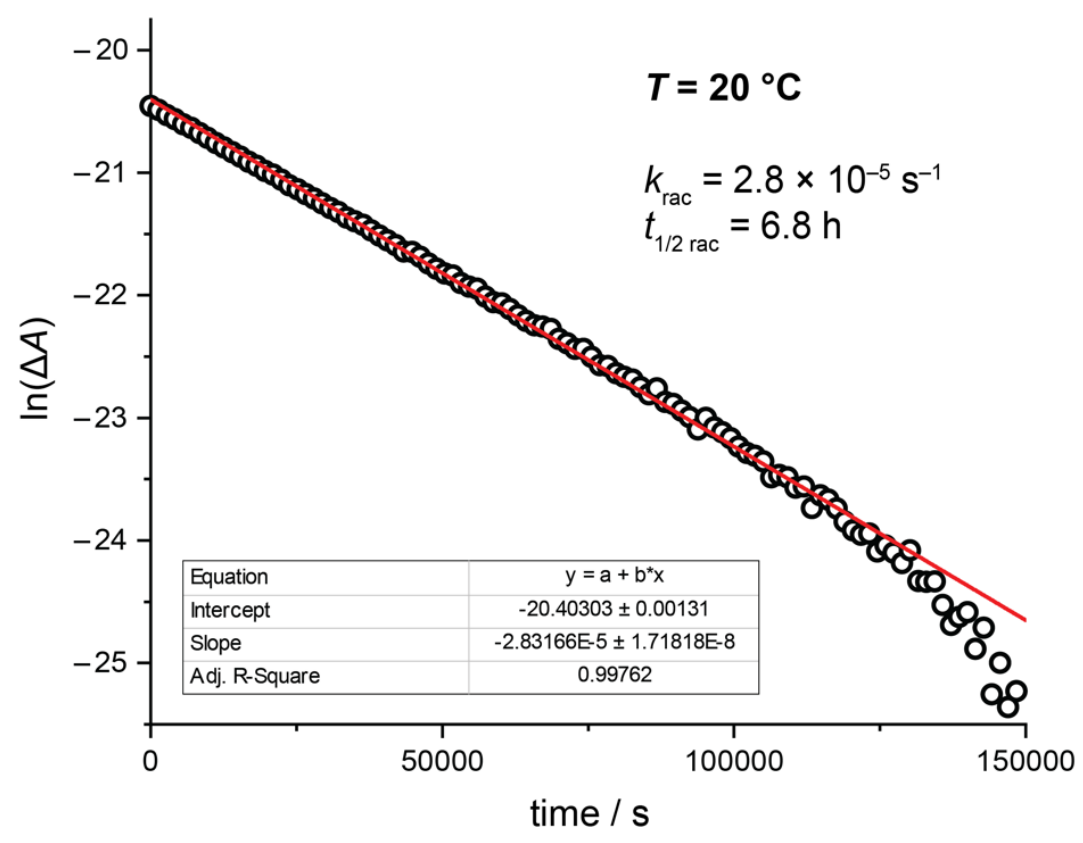

Fig. S32. Racemization of iCor with 5 equiv of ExCage. CD time-course measurement for iCor $\left(1.1 \times 10^{-4} \mathrm{M}\right)$ with 5 equiv of ExCage•6PF $6\left(5.5 \times 10^{-4} \mathrm{M}\right)$ in $\mathrm{MeCN}$ at $20{ }^{\circ} \mathrm{C}$. Data from 0 to $\sim 100000 \mathrm{~s}$ were used for linear fit.

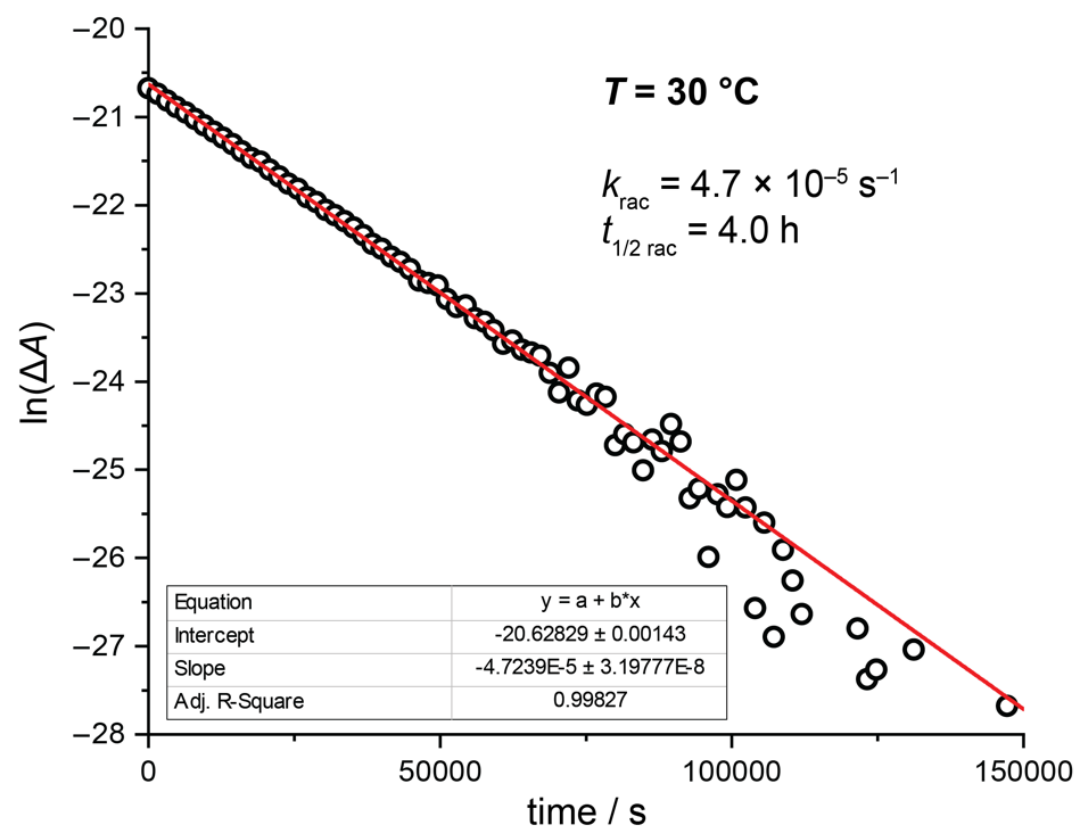

Fig. S33. Racemization of iCor with 5 equiv of ExCage. CD time-course measurement for iCor $\left(1.1 \times 10^{-4} \mathrm{M}\right)$ with 5 equiv of ExCage• $6 \mathrm{PF}_{6}\left(5.5 \times 10^{-4} \mathrm{M}\right)$ in $\mathrm{MeCN}$ at $30{ }^{\circ} \mathrm{C}$. Data from 0 to $\sim 50000 \mathrm{~s}$ were used for linear fit. 


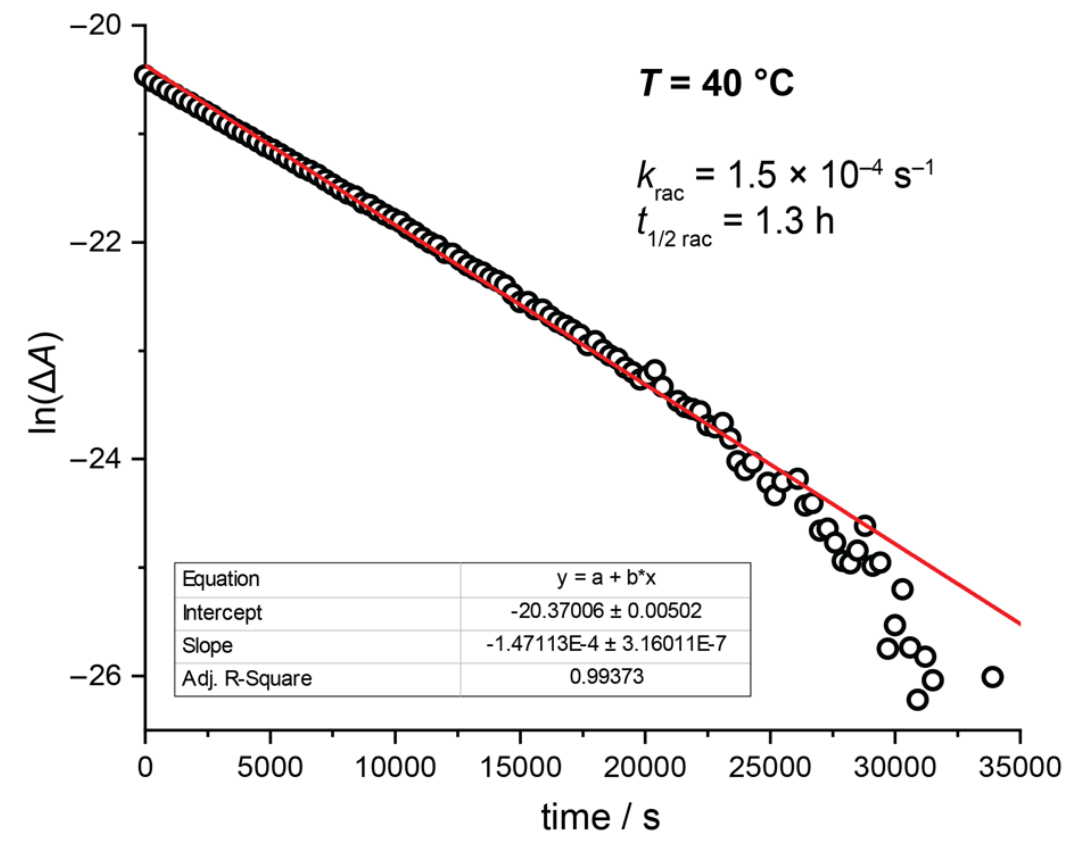

Fig. S34. Racemization of iCor with 5 equiv of ExCage. CD time-course measurement for iCor $\left(1.1 \times 10^{-4} \mathrm{M}\right)$ with 5 equiv of ExCage•6PF $6\left(5.5 \times 10^{-4} \mathrm{M}\right)$ in $\mathrm{MeCN}$ at $40{ }^{\circ} \mathrm{C}$. Data from 0 to $\sim 15000 \mathrm{~s}$ were used for linear fit.

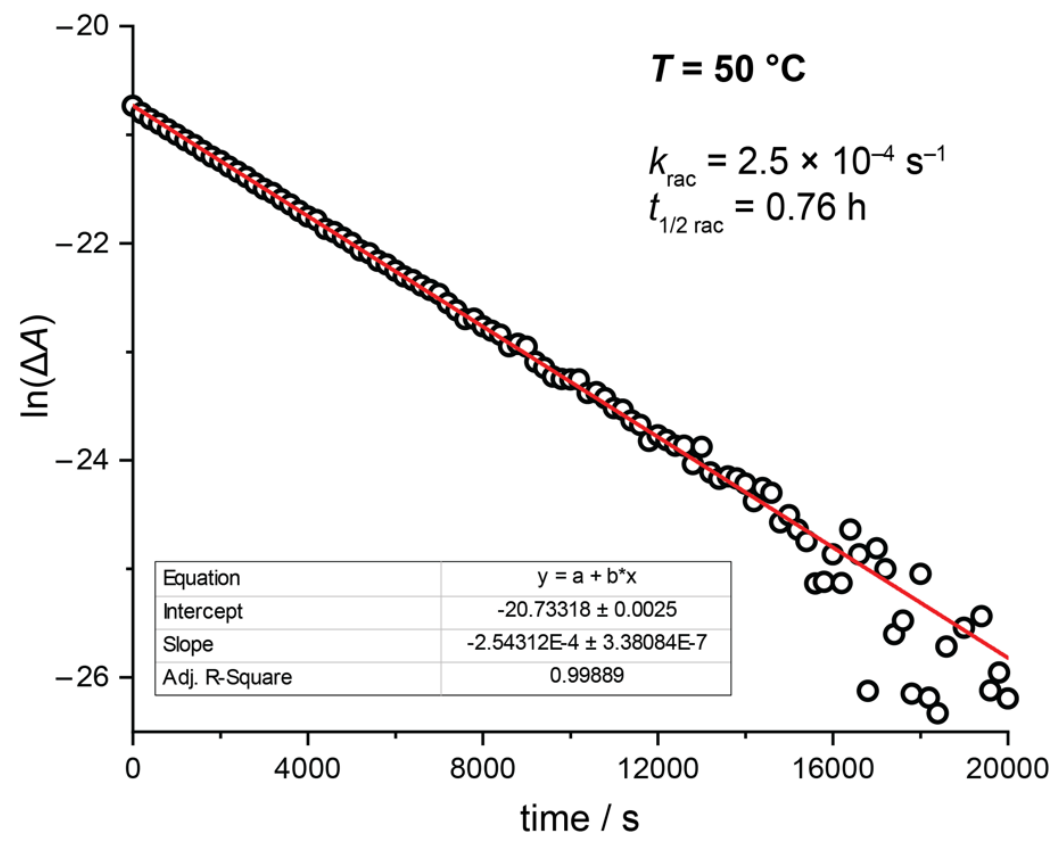

Fig. S35. Racemization of iCor with 5 equiv of ExCage. CD time-course measurement for iCor $\left(1.1 \times 10^{-4} \mathrm{M}\right)$ with 5 equiv of ExCage• $6 \mathrm{PF}_{6}\left(5.5 \times 10^{-4} \mathrm{M}\right)$ in $\mathrm{MeCN}$ at $50{ }^{\circ} \mathrm{C}$. Data from 0 to $\sim 12000 \mathrm{~s}$ were used for linear fit. 


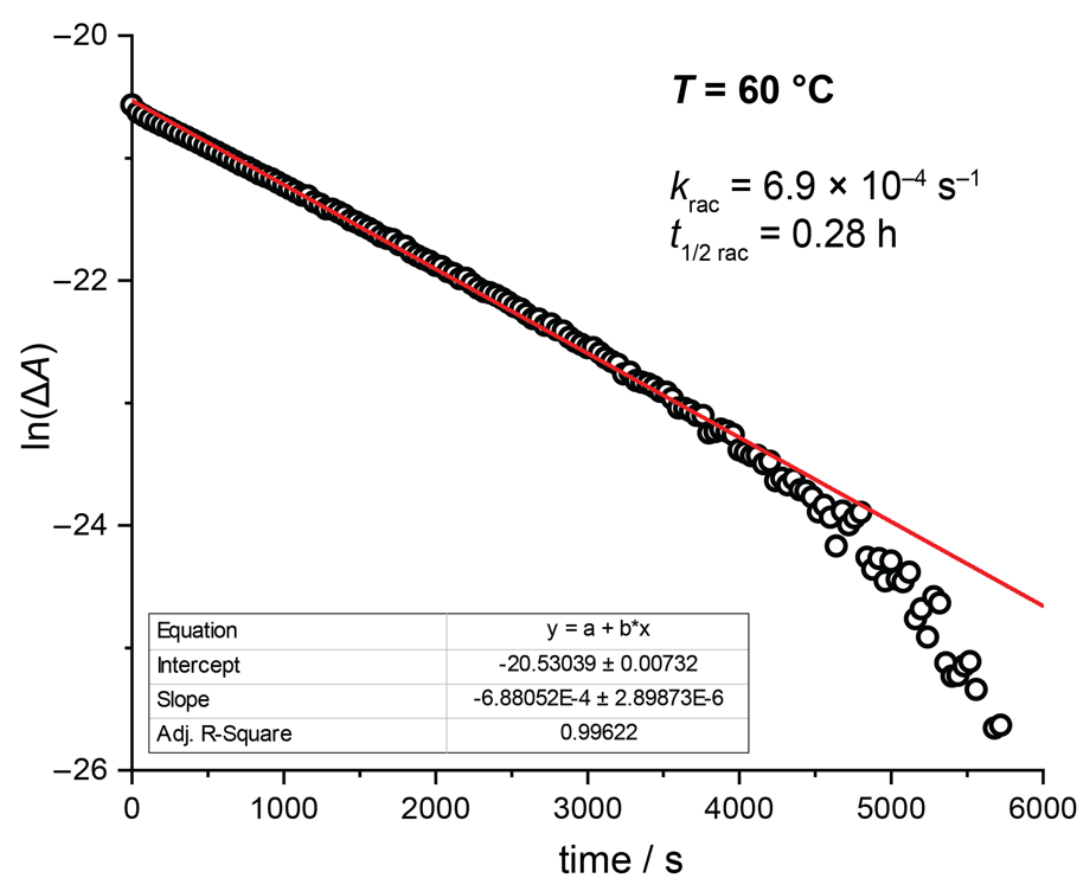

Fig. S36. Racemization of iCor with 5 equiv of ExCage. CD time-course measurement for iCor $\left(1.1 \times 10^{-4} \mathrm{M}\right)$ with 5 equiv of ExCage• $6 \mathrm{PF}_{6}\left(5.5 \times 10^{-4} \mathrm{M}\right)$ in $\mathrm{MeCN}$ at $60{ }^{\circ} \mathrm{C}$. Data from 0 to $\sim 3000 \mathrm{~s}$ were used for linear fit.

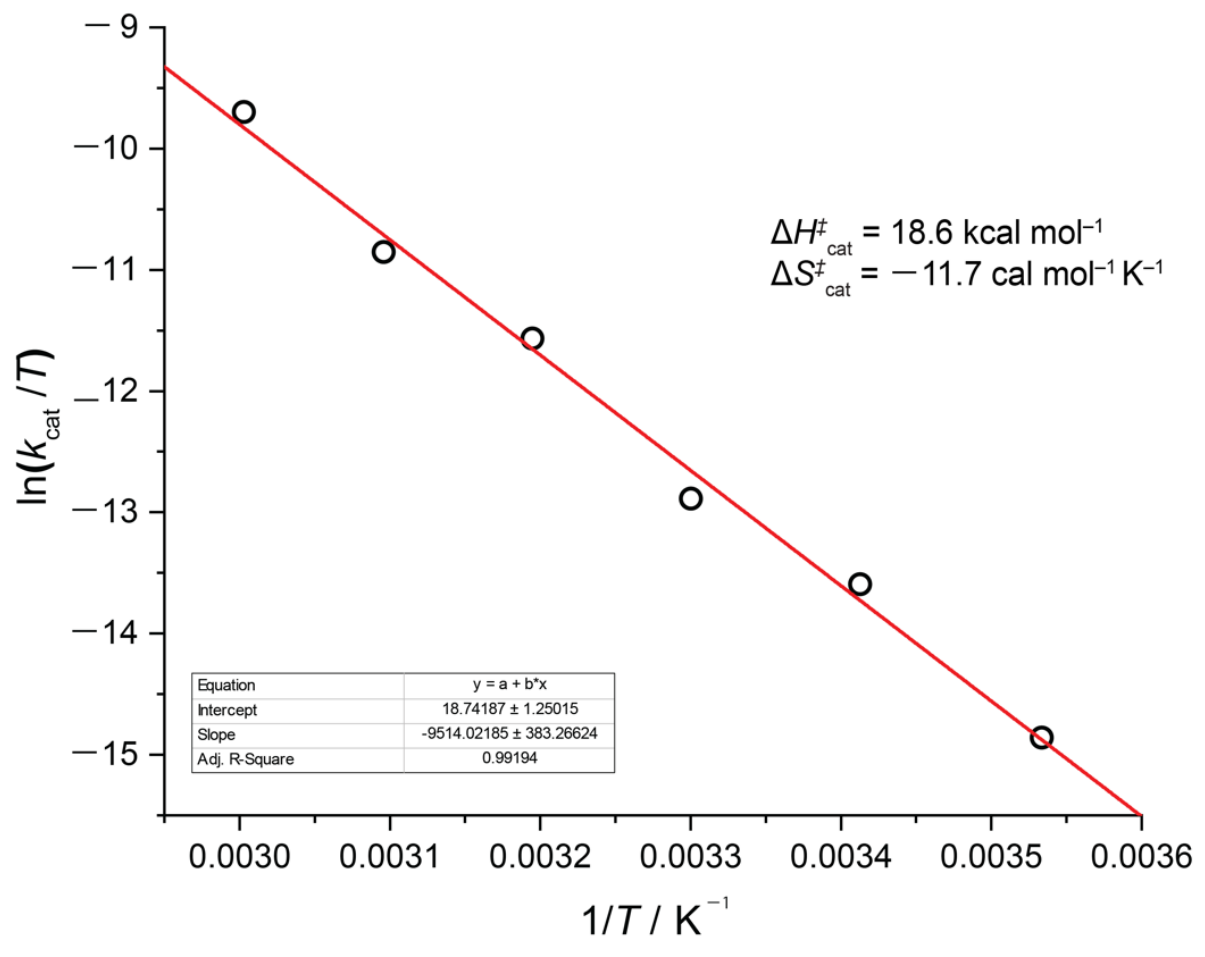

Fig. S37. Eyring plot. Enantiomerization of iCor and ExCage in $\mathrm{MeCN}$. The $k_{\text {cat }}$ values were obtained from the $k_{\text {rac }}$ values reported in Figures S31-S36. The $k_{\text {cat }}$ values were calculated from the equation $k_{\mathrm{obs}}=\mathrm{a} k_{\mathrm{cat}}+(1-\mathrm{a}) k_{\mathrm{non}}$, where $a$ is the percentage of the bound guest determined by using the $K_{\mathrm{a}}$ value and $k_{\mathrm{obs}}=k_{\mathrm{rac}} / 2$. 


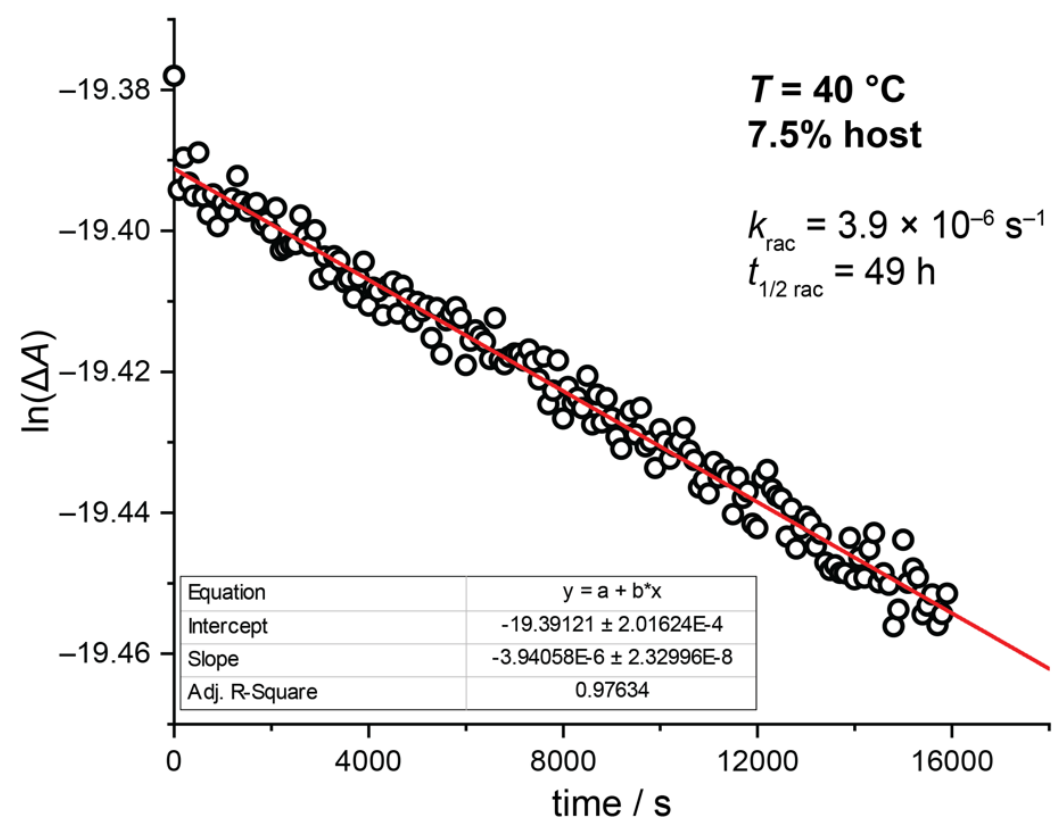

Fig. S38. Racemization of iCor with substoichiometric amount of ExCage. CD time-course measurement for iCor $\left(1.1 \times 10^{-4} \mathrm{M}\right)$ with 0.075 equiv of ExCage•6PF $6\left(8.3 \times 10^{-6} \mathrm{M}\right)$ in $\mathrm{MeCN}$ at $40{ }^{\circ} \mathrm{C}$. Data from 0 to $\sim 12000 \mathrm{~s}$ were used for linear fit.

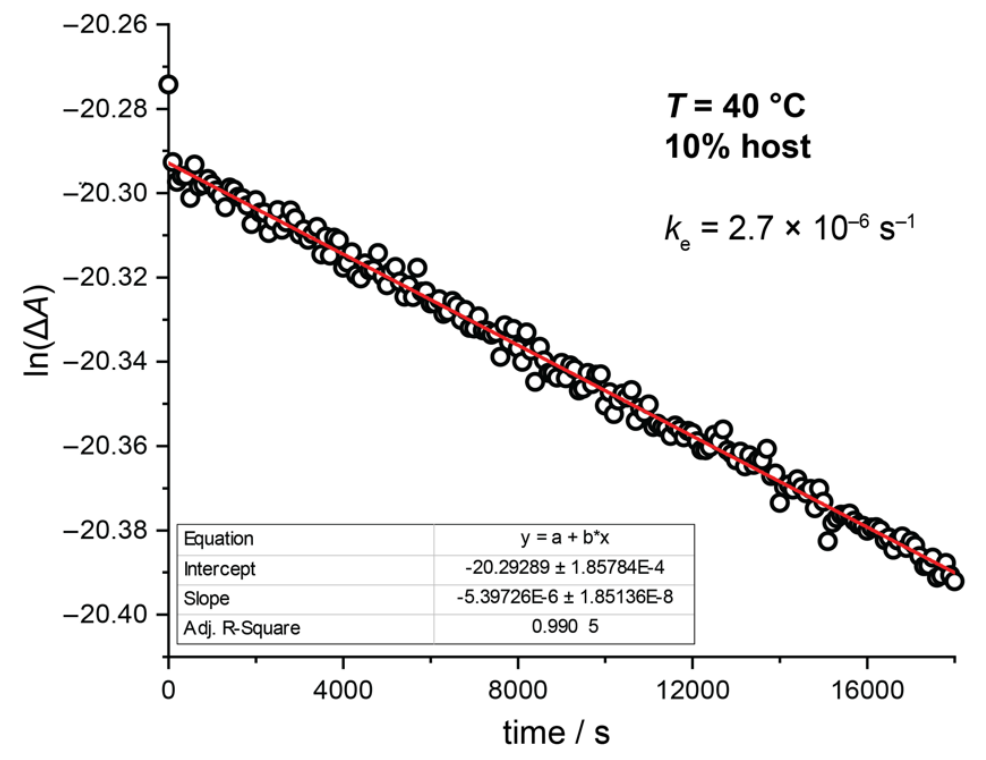

Fig. S39. Racemization of iCor with substoichiometric amount of ExCage. CD time-course measurement for iCor $\left(1.1 \times 10^{-4} \mathrm{M}\right)$ with 0.1 equiv of ExCage• $6 \mathrm{PF}_{6}\left(1.1 \times 10^{-5} \mathrm{M}\right)$ in $\mathrm{MeCN}$ at $40{ }^{\circ} \mathrm{C}$. Data from 0 to $\sim 16000 \mathrm{~s}$ were used for linear fit. 


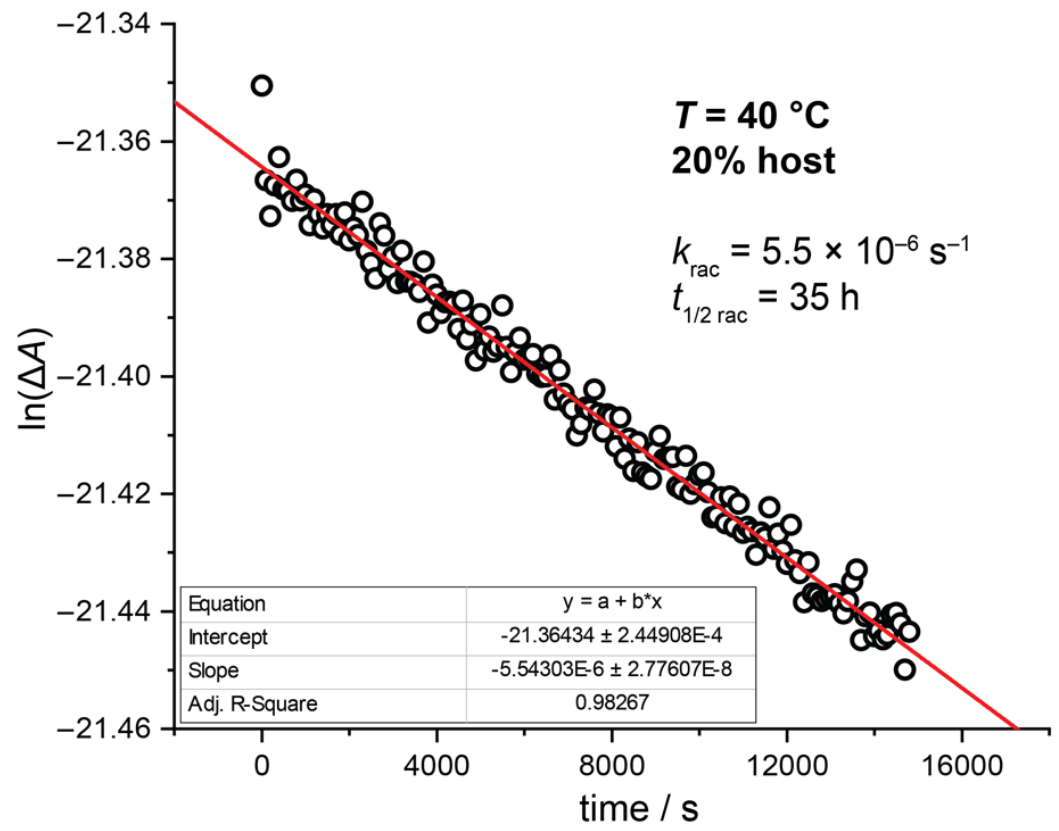

Fig. S40. Racemization of iCor with substoichiometric amount of ExCage. CD time-course measurement for iCor $\left(1.1 \times 10^{-4} \mathrm{M}\right)$ with 0.2 equiv of ExCage• $6 \mathrm{PF}_{6}\left(2.2 \times 10^{-5} \mathrm{M}\right)$ in $\mathrm{MeCN}$ at $40{ }^{\circ} \mathrm{C}$. Data from 0 to $\sim 14000 \mathrm{~s}$ were used for linear fit.

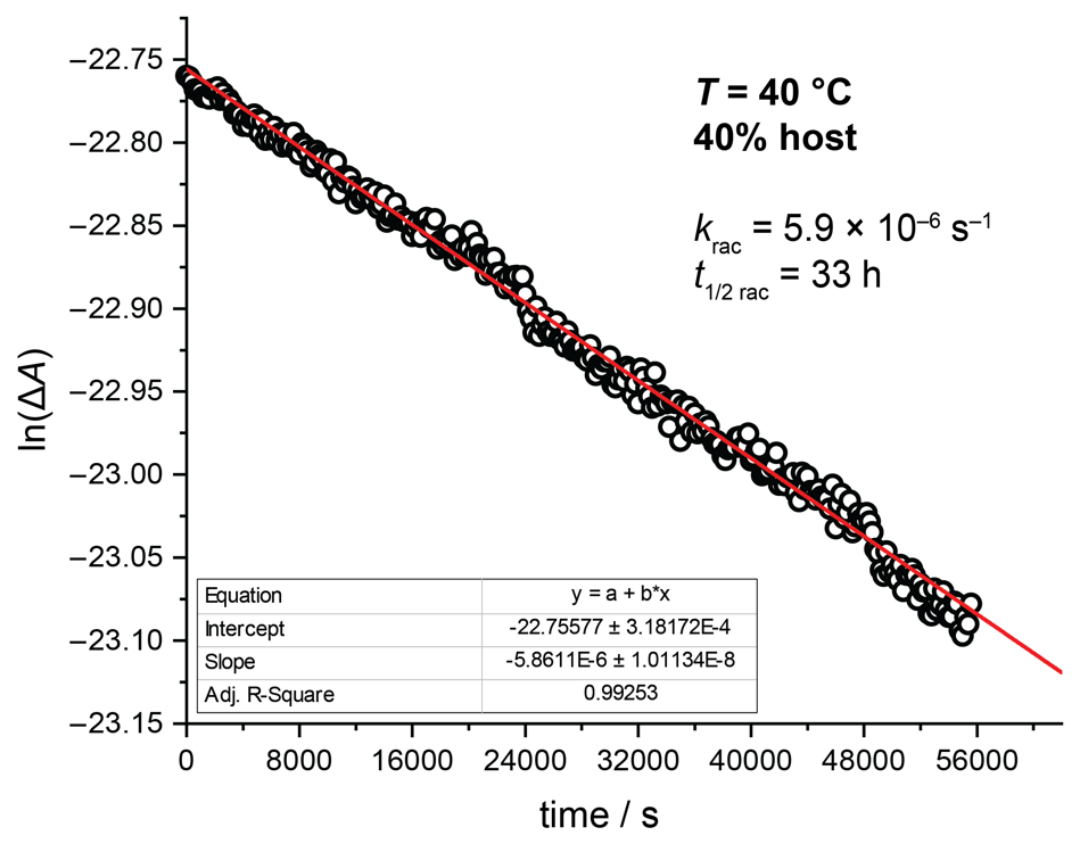

Fig. S41. Racemization of iCor with substoichiometric amount of ExCage. $C D$ time-course measurement for iCor $\left(1.1 \times 10^{-4} \mathrm{M}\right)$ with 0.4 equiv of ExCage $6 \mathrm{PF}_{6}\left(4.4 \times 10^{-5} \mathrm{M}\right)$ in $\mathrm{MeCN}$ at $40{ }^{\circ} \mathrm{C}$. Data from 0 to $\sim 48000 \mathrm{~s}$ were used for linear fit. 


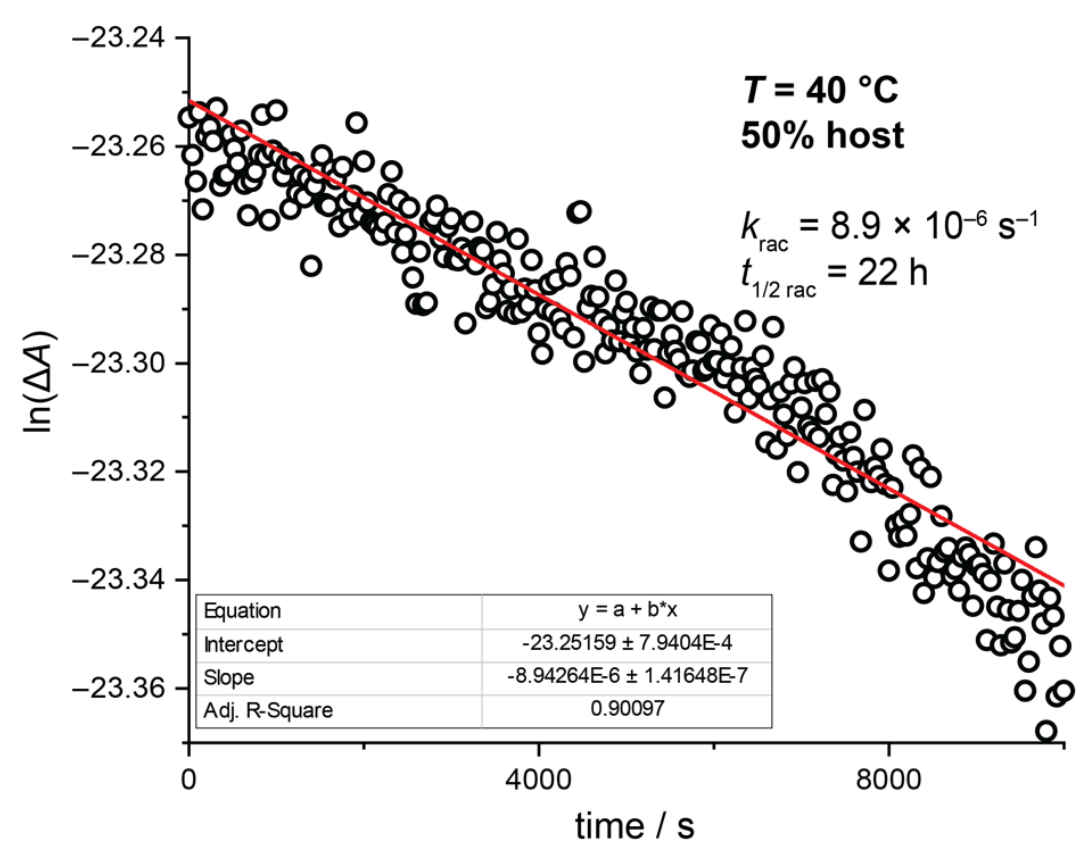

Fig. S42. Racemization of iCor with substoichiometric amount of ExCage. CD time-course measurement for iCor $\left(1.1 \times 10^{-4} \mathrm{M}\right)$ with 0.5 equiv of ExCage $6 \mathrm{PF}_{6}\left(5.5 \times 10^{-5} \mathrm{M}\right)$ in $\mathrm{MeCN}$ at $40{ }^{\circ} \mathrm{C}$. Data from 0 to $\sim 8000 \mathrm{~s}$ were used for linear fit.

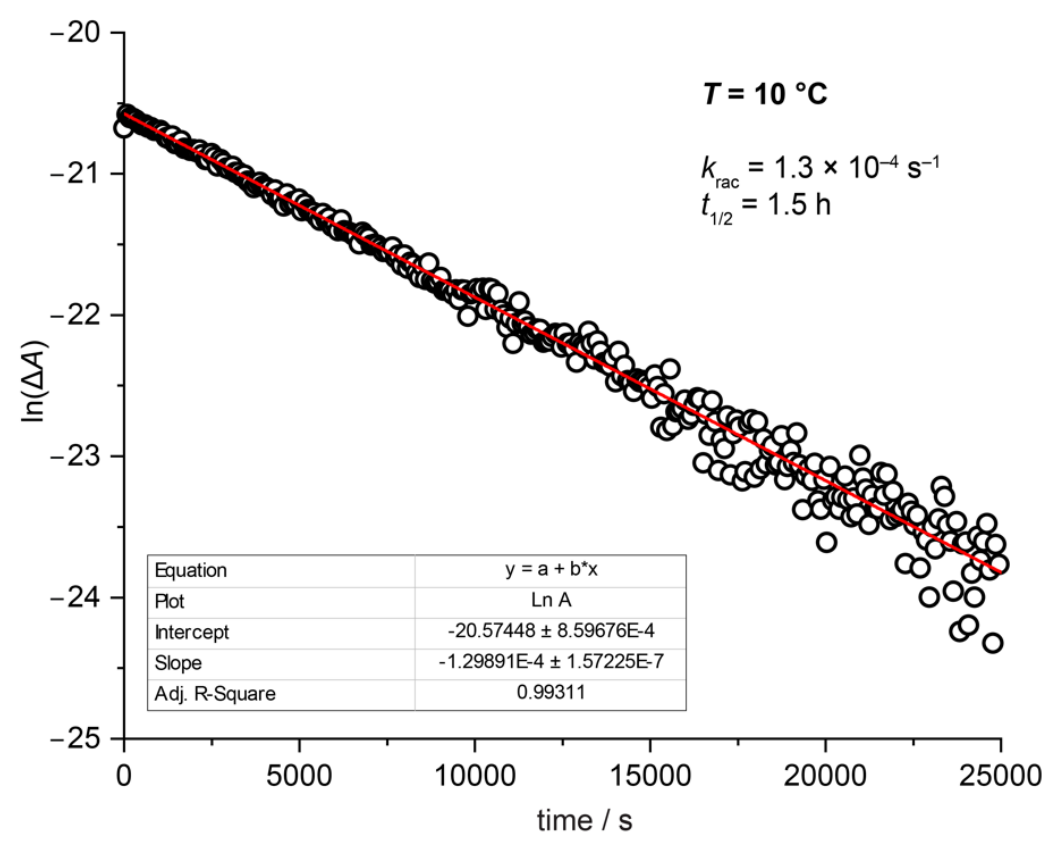

Fig. S43. Racemization of iCor with 137 equiv of ExCage. CD time-course measurement for iCor $\left(1.02 \times 10^{-4} \mathrm{M}\right)$ with 137 equiv of ExCage $6 \mathrm{PF}_{6}\left(1.4 \times 10^{-2} \mathrm{M}\right)$ in $\mathrm{MeCN}$ at $10^{\circ} \mathrm{C}$. Data from 0 to $\sim 8000 \mathrm{~s}$ were used for linear fit. 


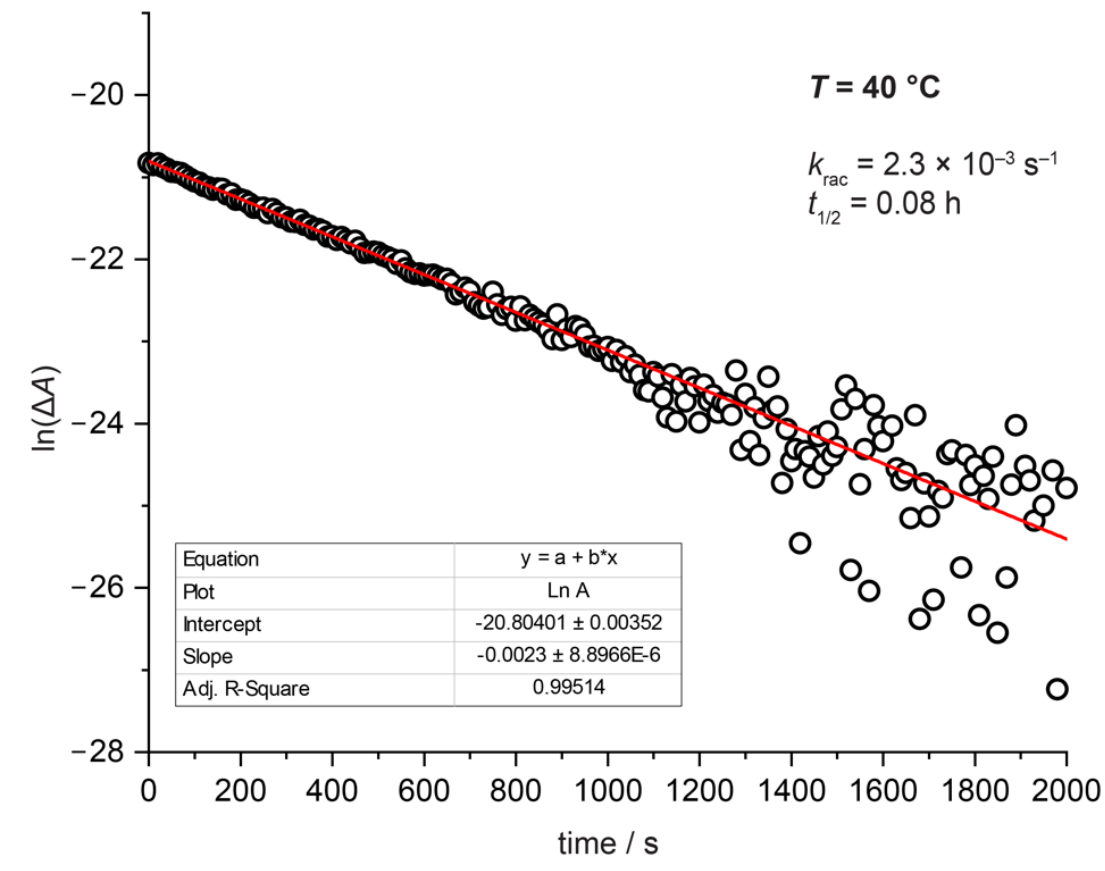

Fig. S44. Racemization of iCor with 137 equiv of ExCage. CD time-course measurement for iCor $\left(1.02 \times 10^{-4} \mathrm{M}\right)$ with 137 equiv of ExCage $6 \mathrm{PF}_{6}\left(1.4 \times 10^{-2} \mathrm{M}\right)$ in $\mathrm{MeCN}$ at $40^{\circ} \mathrm{C}$. Data from 0 to $\sim 800 \mathrm{~s}$ were used for linear fit.

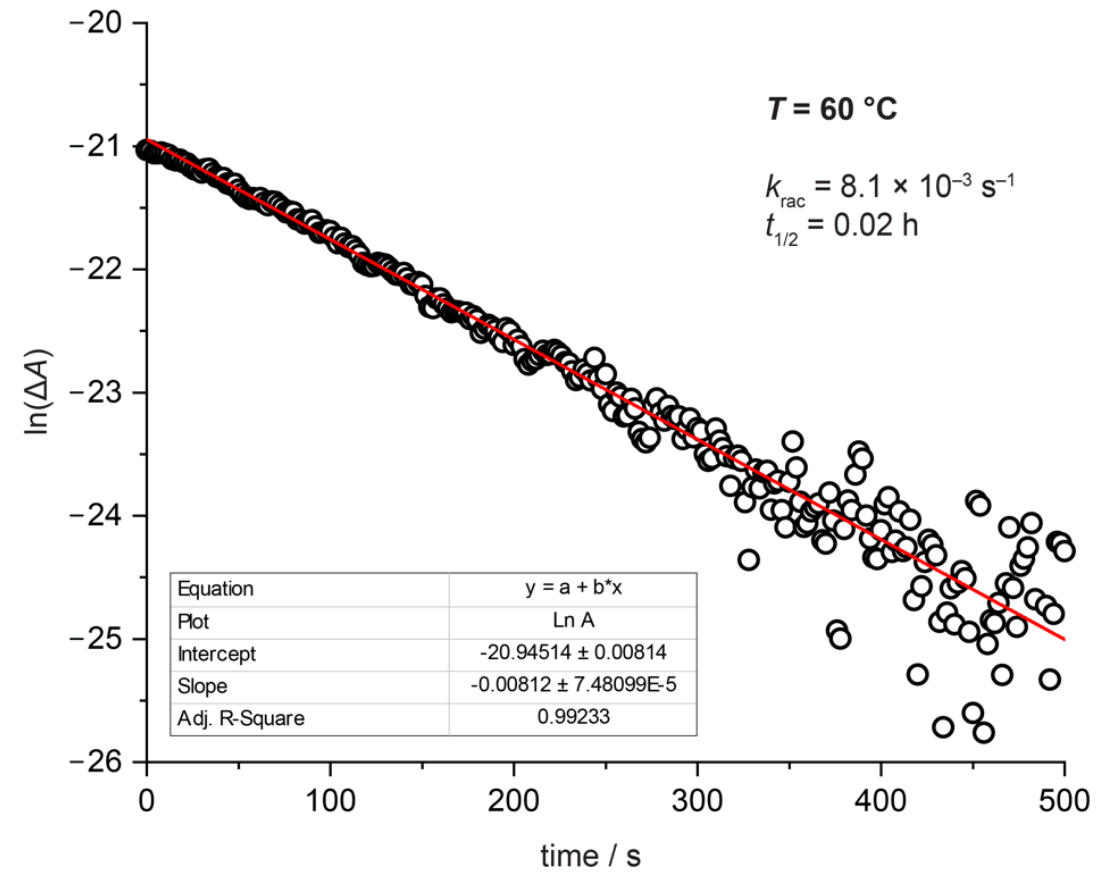

Fig. S45. Racemization of iCor with 137 equiv of ExCage. $C D$ time-course measurement for iCor $\left(1.02 \times 10^{-4} \mathrm{M}\right)$ with 137 equiv of ExCage $6 \mathrm{PF}_{6}\left(1.4 \times 10^{-2} \mathrm{M}\right)$ in $\mathrm{MeCN}$ at $10^{\circ} \mathrm{C}$. Data from 0 to $\sim 200 \mathrm{~s}$ were used for linear fit. 


\section{S5. X-Ray crystallographic data}

Corannulene $(0.5 \mathrm{mg}, 2 \mu \mathrm{mol})$ was added to a solution of ExCage $6 \mathrm{PF}_{6}(2.8 \mathrm{mg}, 1.6 \mu \mathrm{mol})$ in $\mathrm{MeCN}(0.8 \mathrm{~mL})$ and, after it had dissolved, the mixture was passed through a $0.45-\mu \mathrm{m}$ filter equally into three $1-\mathrm{mL}$ tubes. The tubes were placed together in one $20-\mathrm{mL}$ vial containing $\mathrm{PPr}_{2} \mathrm{O}(\sim 3 \mathrm{~mL})$ and the vial was capped. Slow vapor diffusion of $\mathrm{iPr}_{2} \mathrm{O}$ into the 1.25:1 solution of corannulene and ExCage $6 \mathrm{PF}_{6}$ in $\mathrm{MeCN}$ over the period of 2 days yielded yellow single crystals of Cor $\subset$ ExCage $6 \mathrm{PF}_{6}(\mathrm{MeCN})_{9}$ (space group $\left.\mathrm{Pbcm}\right)$. The solid-state structure of Cor $C$ ExCage $\cdot 6 \mathrm{PF}_{6}(\mathrm{MeCN})_{9}$ is shown in fig. $\mathrm{S} 43$.

Phenantroline $(0.4 \mathrm{mg}, 2 \mu \mathrm{mol})$ was added to a solution of ExCage $6 \mathrm{PF}_{6}(2.8 \mathrm{mg}, 1.6 \mu \mathrm{mol})$ in $\mathrm{MeCN}(0.8 \mathrm{~mL})$ and, after it had dissolved, the mixture was passed through a $0.45-\mu \mathrm{m}$ filter equally into three $1-\mathrm{mL}$ tubes. The tubes were placed together in one $20-\mathrm{mL}$ vial containing $i \mathrm{Pr}_{2} \mathrm{O}(\sim 3 \mathrm{~mL})$ and the vial was capped. Slow vapor diffusion of $\mathrm{iPr}_{2} \mathrm{O}$ into the $1.25: 1$ solution of corannulene and $\mathbf{E x C a g e} \cdot 6 \mathrm{PF}_{6}$ in $\mathrm{MeCN}$ over the period of 2 days yielded brown single crystals of phenantroline $\subset$ ExCage $6 \mathrm{PF}_{6}(\mathrm{MeCN})_{8}$ (space group $\left.\mathrm{Cmcm}\right)$. The solid-state structure of phenantrolinec Ex $\mathbf{x a g e} \cdot 6 \mathrm{PF}_{6}(\mathrm{MeCN})_{8}$ is shown in fig. $\mathrm{S} 44$.

Single-crystal X-ray diffraction data were collected at 160(1) K on a a Rigaku OD XtaLAB Synergy, Dualflex, Pilatus $200 \mathrm{~K}$ diffractometer using a single wavelength $\mathrm{X}$-ray source $(\mathrm{Cu}$ K $\alpha$ radiation: $\lambda=1.54184 \AA$ ) from a micro-focus sealed X-ray tube and an Oxford liquidnitrogen Cryostream cooler. The selected suitable single crystal was mounted using polybutene oil on a flexible loop fixed on a goniometer head and immediately transferred to the diffractometer. Pre-experiment, data collection, data reduction and analytical absorption correction ${ }^{4}$ were performed with the program suite CrysAlisPro. ${ }^{5}$ Using Olex $2,{ }^{5}$ the structure was solved with the SHELXT ${ }^{6}$ small molecule structure solution program and refined with the SHELXL2018/3 program package ${ }^{7}$ by full-matrix least-squares minimization on $F^{2}$. PLATON ${ }^{8}$ was used to check the result of the X-ray analysis. For more details about the data collection and refinement parameters, see the CIF file.

One pyridine ring is partially disordered over two sets of positions with site-occupancy factors of $0.455(14)$ and $0.545(14)$. The cavity formed by the $\mathrm{C}_{66} \mathrm{H}_{54} \mathrm{~N}_{6}{ }^{6+}$ cation is occupied by a neutral molecule of $\mathrm{C}_{20} \mathrm{H}_{10}$. The cavity is only partially occupied by the guest molecule, the refinement led to an occupancy of $69.2 \%$. The $\mathrm{C}_{20} \mathrm{H}_{10}$ molecule is severely disordered over four sets of positions: two sets with a site-occupancy factor of 0.109(4) and two sets with 0.237(4), the molecule(s) being located near a mirror plane. Solvent molecules of acetonitrile are distinguishable around the main molecules but most of them are also disordered. A solvent 
mask $^{5}$ was calculated and 759 electrons corresponding to solvent molecules were found per unit cell. This is consistent with the presence of nine molecules of acetonitrile for one $\mathrm{C}_{66} \mathrm{H}_{54} \mathrm{~N}_{6}{ }^{6+}$ cation and six $\mathrm{PF}_{6}{ }^{-}$anions. The solvent molecules were introduced in the CIF (formulas) despite they were not refined in the model, it causes several alerts in the checkCIF report. Many restraints had to be used in the model to correct the geometry of the disordered moieties and the thermal parameters of the corresponding atoms.

The phenantroline guest is fully disordered over two sets of positions with a site-occupancy factor of 0.5. A solvent mask was used in Olex2 to take into account the residual electron density attributed to disordered solvent molecules of acetonitrile outside the cage (171 electrons for one cage, i.e., eight solvent molecules of acetonitrile). One solvent molecule of acetonitrile in the asymmetric unit could be refined). The same solvent mask was used to calculate the number of electrons inside the cage to confirm the presence of one guest molecule per cage (found: 101 electrons, phenantroline: 94 electrons). Despite they are not present in the final model, the formula moiety and the formula sum include the atoms of the solvent molecules leading to many alerts in the checkCIF report. 
a

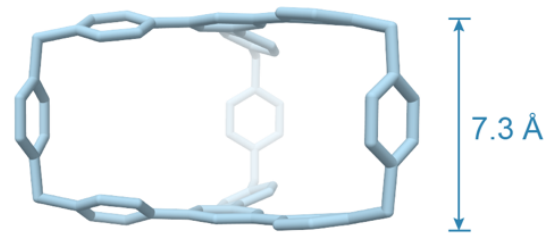

b
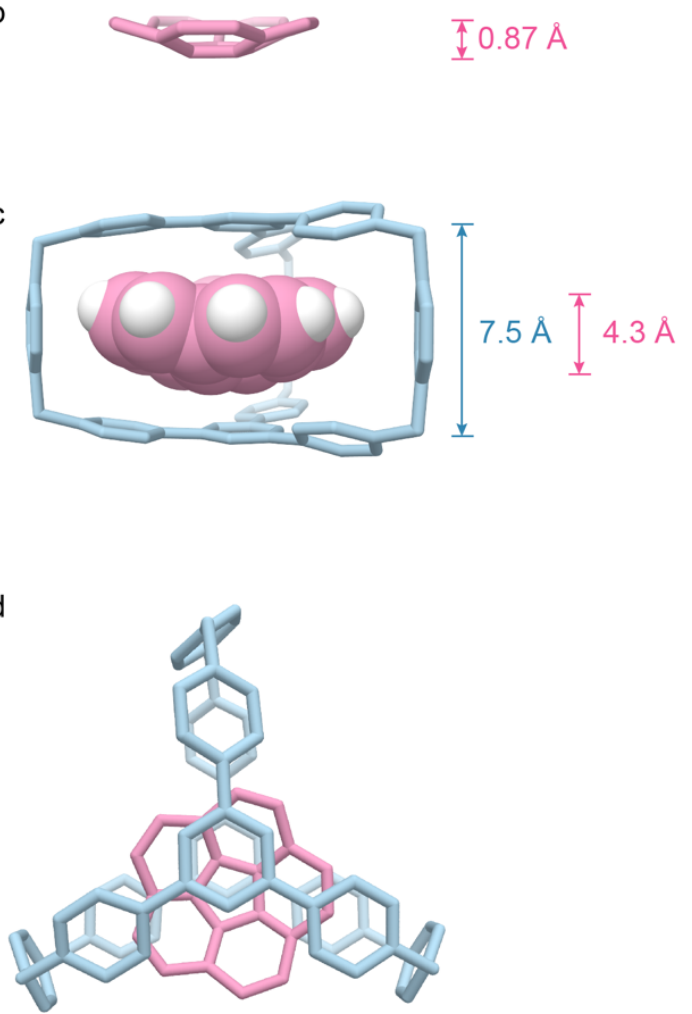
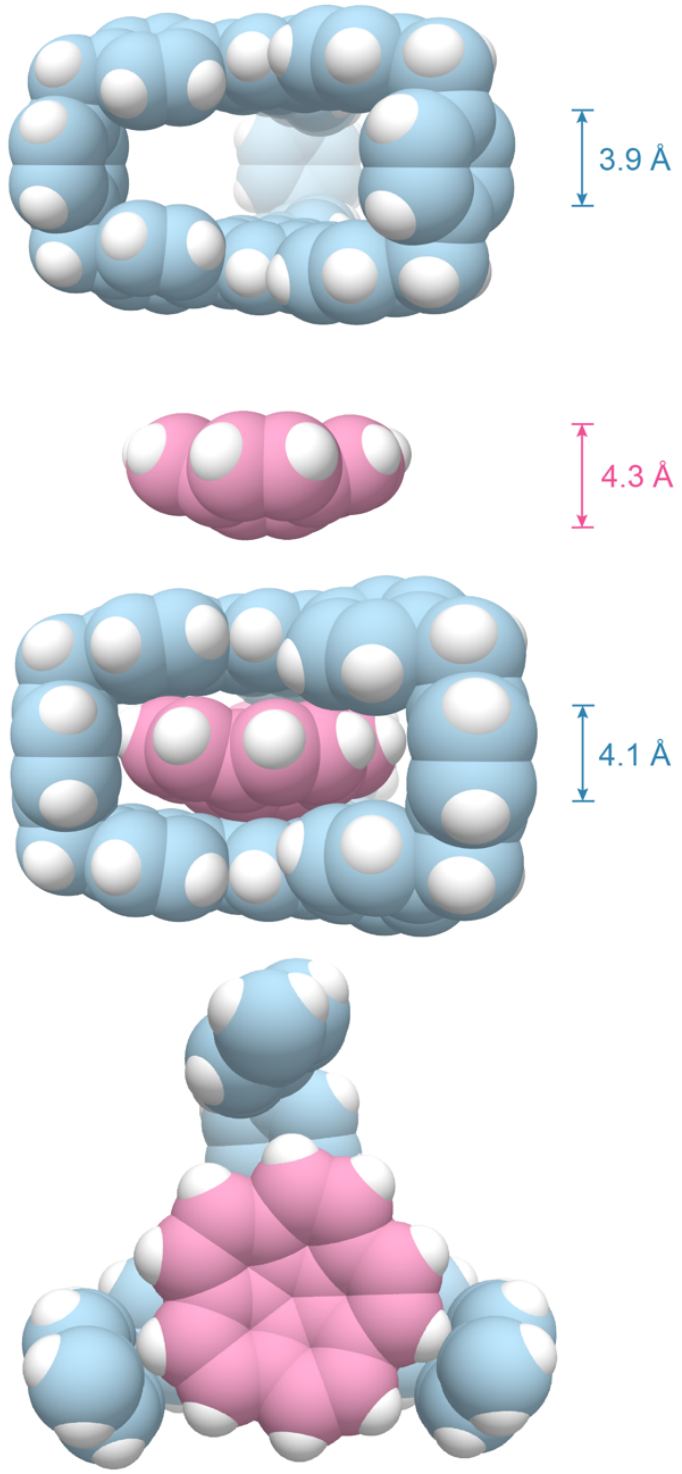

Fig. S46. The solid-state structures obtained by X-ray crystallography. a, ExCage ${ }^{6+}$. b, Cor. c, side view of Cor $\subset$ ExCage $^{6+}$. d, top view of CorсExCage ${ }^{6+}$.

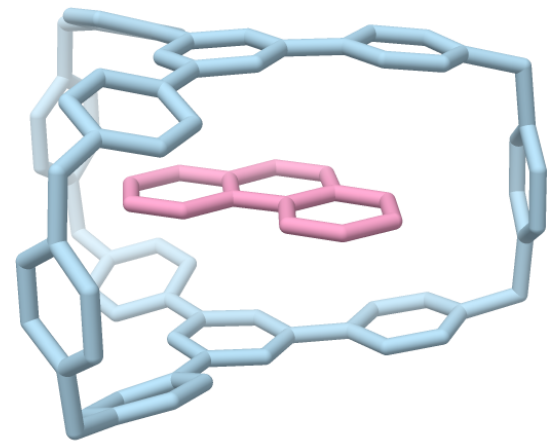

Fig. S47. The solid-state structure obtained by X-ray crystallography. Side view of phenantroline $\subset$ ExCage ${ }^{6+}$. 
Table S4. Crystal data and structure refinement for Cor $\subset$ ExCage. (CCDC no. 2112636)

Identification code

Empirical formula

Formula weight

Temperature / K

Crystal system

Space group

$a / \AA$

$b / \AA$

$c / \AA$

$\alpha / 0$

$\beta / \circ$

$\gamma / \circ$

Volume / $\AA^{3}$

Z

$\rho_{\text {calc }} / \mathrm{g} \mathrm{cm}^{-3}$

$\mu / \mathrm{mm}^{-1}$

$F(000)$

Crystal size $/ \mathrm{mm}^{3}$

Radiation

$2 \Theta$ range for data collection $/^{\circ}$

Index ranges

Reflections collected

Independent reflections

Data/restraints/parameters

Goodness-of-fit on $F^{2}$

Final $R$ indexes $[I>=2 \sigma(I)]$

Final $R$ indexes [all data]

Largest diff. peak/hole / e $\AA^{-3}$

\section{Cor $C$ ExCage}

$\mathrm{C}_{97.88} \mathrm{H}_{87.94} \mathrm{~F}_{36} \mathrm{~N}_{15} \mathrm{P}_{6}$

2344.15

160(1)

orthorhombic

$\mathrm{Pbcm}$

17.94241(19)

28.8204(3)

$21.7883(2)$

90

90

90

$11266.9(2)$

4

1.382

1.870

4777.0

$0.17 \times 0.16 \times 0.09$

$\mathrm{Cu} \mathrm{K \alpha}(\lambda=1.54184)$

5.802 to 149

$-22 \leq h \leq 19,-35 \leq k \leq 36,-27 \leq l \leq 25$

64012

$11806\left[R_{\text {int }}=0.0342, R_{\text {sigma }}=0.0175\right]$

$11806 / 1396 / 859$

1.657

$R_{1}=0.1146, w R_{2}=0.3710$

$R_{1}=0.1360, w R_{2}=0.4018$

$1.66 /-0.77$ 
Table S5. Crystal data and structure refinement for phenantroline $\subset$ ExCage.

(CCDC no. 2112638)

Identification code

phenantroline $\subset$ ExCage

Empirical formula

$\mathrm{C}_{98} \mathrm{H}_{92} \mathrm{~F}_{36} \mathrm{~N}_{18} \mathrm{P}_{6}$

Formula weight

2391.71

Temperature / K

160(1)

Crystal system

orthorhombic

Space group

$\mathrm{Cmcm}$

$a / \AA$

18.1040(2)

$b / \AA$

28.6742(3)

$c / \AA$

$21.4845(2)$

$\alpha /{ }^{\circ}$

90

$\beta / \circ$

90

$\gamma / \circ$

90

Volume / $\AA^{3}$

11153.0(2)

Z

4

$\rho_{\text {calc }} / \mathrm{g} \mathrm{cm}^{-3} \quad 1.424$

$\mu / \mathrm{mm}^{-1} \quad 1.908$

$F(000) \quad 4880.0$

Crystal size $/ \mathrm{mm}^{3} \quad 0.24 \times 0.17 \times 0.16$

Radiation $\quad \mathrm{Cu} \mathrm{K \alpha}(\lambda=1.54184)$

$2 \Theta$ range for data collection / ${ }^{\circ} \quad 5.774$ to 136.474

Index ranges

$-21 \leq h \leq 21,-34 \leq k \leq 34,-25 \leq l \leq 25$

Reflections collected

53268

Independent reflections

$5429\left[R_{\text {int }}=0.0283, R_{\text {sigma }}=0.0106\right]$

Data/restraints/parameters

$5429 / 28 / 319$

Goodness-of-fit on $F^{2}$

2.002

Final $R$ indexes $[I>=2 \sigma(I)]$

$R_{1}=0.1222, w R_{2}=0.3978$

Final $R$ indexes [all data]

$R_{1}=0.1272, w R_{2}=0.4130$

Largest diff. peak/hole / e $\AA^{-3}$

$1.21 /-0.66$ 


\section{S6. Computational data}

Table S6. B97-D/def2-TZVPD(water) results for the catalysis process ( $\mathrm{kcal} \mathrm{mol}^{-1}$ ).

\begin{tabular}{|c|c|}
\hline System & $\Delta \boldsymbol{H}$ \\
\hline iCor & \\
\hline $\begin{array}{l}\text { bowl } \rightarrow \text { flat } \\
\text { bowl in cavity } \rightarrow \text { flat in cavity }\end{array}$ & $\begin{array}{l}-27.71 \\
-20.04\end{array}$ \\
\hline$\Delta \Delta H^{*}$ calc-relax & 7.67 \\
\hline $\begin{array}{l}\text { bowl (opt) }+ \text { cage (opt) } \rightarrow \text { bowl in cavity (opt) } \\
\text { flat (opt) }+ \text { cage (opt) } \rightarrow \text { flat in cavity (opt) }\end{array}$ & $\begin{array}{l}-41.11 \\
-48.78\end{array}$ \\
\hline$\Delta \Delta H^{*}$ calc-relax & 7.67 \\
\hline $\begin{array}{l}{[\text { Fixed bowl sp }+ \text { fixed shell } \mathrm{sp}]^{*} \rightarrow \text { opt complex with bowl }} \\
{[\text { Fixed flat } \mathrm{sp}+\text { fixed shell } \mathrm{sp}]^{*} \rightarrow \text { opt complex with flat }}\end{array}$ & $\begin{array}{l}-44.78 \\
-51.79\end{array}$ \\
\hline $\begin{aligned} \Delta \Delta H^{\ddagger} \text { calc-restrict } \\
\Delta \Delta H^{\ddagger} \text { calc-relax } \\
-\Delta \Delta H^{\ddagger} \text { calc-rerstrict }\end{aligned}$ & $\begin{array}{l}7.01 \\
0.66\end{array}$ \\
\hline $\begin{array}{l}\text { Geometry Deformation Energies } \\
\text { [Fixed bowl as in complex] - free opt bowl } \\
\text { [Fixed cage as in complex] - free opt cage } \\
\text { [Fixed flat as in complex] - free opt flat } \\
\text { [Fixed cage as in complex] - free opt cage }\end{array}$ & $\begin{array}{l}-0.95 \\
-0.15 \\
-2.71 \\
-2.61\end{array}$ \\
\hline Corannulene & \\
\hline $\begin{array}{l}\text { bowl } \rightarrow \text { flat } \\
\text { bowl in cavity } \rightarrow \text { flat in cavity }\end{array}$ & $\begin{array}{l}-10.58 \\
-5.26\end{array}$ \\
\hline$\Delta \Delta H^{*}$ calc-relax & 5.32 \\
\hline $\begin{array}{l}\text { bowl (opt) }+ \text { cage (opt) } \rightarrow \text { bowl in cavity (opt) } \\
\text { flat }(o p t)+\text { cage }(o p t) \rightarrow \text { flat in cavity (opt) }\end{array}$ & $\begin{array}{l}-36.73 \\
-42.06\end{array}$ \\
\hline$\Delta \Delta H^{*}$ calc-relax & 5.33 \\
\hline $\begin{array}{l}{[\text { Fixed bowl sp }+ \text { fixed shell } \mathrm{sp}]^{*} \rightarrow \text { opt complex with bowl }} \\
{[\text { Fixed flat } \mathrm{sp}+\text { fixed shell } \mathrm{sp}]^{*} \rightarrow \text { opt complex with flat }}\end{array}$ & $\begin{array}{l}-40.23 \\
-44.66\end{array}$ \\
\hline $\begin{array}{r}\Delta \Delta H^{\ddagger} \text { calc-restrict } \\
\Delta \Delta H^{*} \text { calc-relax }-\Delta \Delta H^{*} \text { calc-rerstrict }\end{array}$ & $\begin{array}{r}4.43 \\
-0.9\end{array}$ \\
\hline $\begin{array}{l}\text { Geometry Deformation Energies } \\
\text { [Fixed bowl as in complex] - free opt bowl } \\
\text { [Fixed cage as in complex] - free opt cage }\end{array}$ & $\begin{array}{l}-0.78 \\
-0.08\end{array}$ \\
\hline $\begin{array}{l}\text { [Fixed flat as in complex] - free opt flat } \\
\text { [Fixed cage as in complex] - free opt cage }\end{array}$ & $\begin{array}{l}-2.71 \\
-2.51\end{array}$ \\
\hline
\end{tabular}

*Single-point (sp) energy for geometries taken from optimized complex geometry. 


\section{Cartesian coordinates of the optimized geometries}

iCor (flat) in ExCage - water solvent

Transition State, imaginary mode -110.5

164

C $\quad 0.8249762144 \quad-1.2034025443 \quad 3.3117944406$

C $\quad 0.8249762144 \quad 1.2034025443 \quad 3.3117944406$

C $\quad-1.2592687675 \quad 0 . \quad-3.5035701555$

C $0.8249762144 \quad-1.2034025443 \quad-3.3117944406$

$\begin{array}{llll}\text { C } & 0.8249762144 & 1.2034025443 & -3.3117944406\end{array}$

$\begin{array}{llll}\text { C } & -1.2592687675 & 0 . & 3.5035701555\end{array}$

H $1.3455391946-2.1459423118 \quad 3.2150513589$

H $1.3455391946 \quad 2.1459423118 \quad 3.2150513589$

$\mathrm{H} \quad-2.3323720148 \quad 0 . \quad-3.6477167451$

H $1.3455391946 \quad-2.1459423118 \quad-3.2150513589$

H $1.3455391946 \quad 2.1459423118$-3.2150513589

H $\quad-2.3323720148 \quad 0 . \quad 3.6477167451$

C $-0.5732900088 \quad 1.2193266198 \quad 3.4242527433$

C $\quad-0.5732900088-1.2193266198 \quad 3.4242527433$

C $\quad \begin{array}{llll}\text { C } & 1.5489701386 & 0 . & -3.2866562936\end{array}$

C $\quad-0.5732900088 \quad 1.2193266198 \quad-3.4242527433$

$\begin{array}{lllll}\text { C } & -0.5732900088 & -1.2193266198 & -3.4242527433\end{array}$

C $1.5489701386 \quad 0 . \quad 3.2866562936$

C $-1.3127597692 \quad 2.4978823501 \quad 3.4197970033$

$\begin{array}{llll}\text { C } & -1.3127597692 & -2.4978823501 & 3.4197970033\end{array}$

$\begin{array}{llll}\text { C } & 3.0313744862 & 0 . & -3.2273126763\end{array}$

$\begin{array}{llll}\text { C } & -1.3127597692 & 2.4978823501 & -3.4197970033\end{array}$

$\begin{array}{llll}\text { C } & -1.3127597692 & -2.4978823501 & -3.4197970033\end{array}$

C $3.03137448620 . \quad 3.2273126763$

$\begin{array}{llll}\text { C } & -2.6748570483 & 2.5534248948 & 3.0603784987\end{array}$

C $\quad-0.6882455113 \quad-3.7203481766 \quad 3.7296905978$

$\begin{array}{llll}\text { C } & 3.780117558 & 1.1943687751 & -3.2002677007\end{array}$

$\begin{array}{llll}\text { C } & -2.6748570483 & 2.5534248948 & -3.0603784987\end{array}$

$\begin{array}{llll}\text { C } & -0.6882455113 & -3.7203481766 & -3.7296905978\end{array}$

$\begin{array}{llll}\text { C } & 3.780117558 & -1.1943687751 & -3.2002677007\end{array}$

C $-0.6882455113 \quad 3.7203481766 \quad-3.7296905978$

$\begin{array}{llll}\text { C } & -2.6748570483 & -2.5534248948 & -3.0603784987\end{array}$

$\begin{array}{llll}\text { C } & 3.780117558 & -1.1943687751 & 3.2002677007\end{array}$

C $\quad-0.6882455113 \quad 3.7203481766 \quad 3.7296905978$

$\begin{array}{llll}\text { C } & -2.6748570483 & -2.5534248948 & 3.0603784987\end{array}$

$\begin{array}{llll}\text { C } & 3.780117558 & 1.1943687751 & 3.2002677007\end{array}$

H $\quad-3.2340971317 \quad 1.6653019325 \quad 2.7962124204$

H $\quad 0.3425808073 \quad-3.7679541553 \quad 4.0597119446$

H $3.3139290025 \quad 2.1703386417 \quad-3.2193681656$

H $\quad-3.2340971317 \quad 1.6653019325 \quad-2.7962124204$

H $\quad 0.3425808073 \quad-3.7679541553 \quad-4.0597119446$

H $3.3139290025 \quad-2.1703386417 \quad-3.2193681656$

H $\quad 0.3425808073 \quad 3.7679541553 \quad-4.0597119446$

H $\quad-3.2340971317 \quad-1.6653019325 \quad-2.7962124204$

H $3.3139290025 \quad-2.1703386417 \quad 3.2193681656$

$\mathrm{H} \quad 0.3425808073 \quad 3.7679541553 \quad 4.0597119446$

H $\quad-3.2340971317 \quad-1.6653019325 \quad 2.7962124204$

H $3.3139290025 \quad 2.1703386417 \quad 3.2193681656$

$\begin{array}{llll}\text { C } & -3.325888938 & 3.7631074405 & 2.9685329219\end{array}$

C $-1.3787373661 \quad-4.9110083602 \quad 3.6096975912$ 

C $\quad 5.1587735156 \quad 1.1704486208 \quad-3.1315823919$
$\begin{array}{llll}\text { C } & -3.325888938 & 3.7631074405 & -2.9685329219\end{array}$
C $-1.3787373661 \quad-4.9110083602-3.6096975912$
$\begin{array}{llll}\text { C } & 5.1587735156 & -1.1704486208 & -3.1315823919\end{array}$
$\begin{array}{llll}\text { C } & -1.3787373661 & 4.9110083602 & -3.6096975912\end{array}$
$\begin{array}{llll}\text { C } & -3.325888938 & -3.7631074405 & -2.9685329219\end{array}$
C $5.1587735156-1.1704486208 \quad 3.1315823919$
$\begin{array}{llll}\text { C } & -1.3787373661 & 4.9110083602 & 3.6096975912\end{array}$
$\begin{array}{llll}\text { C } & -3.325888938 & -3.7631074405 & 2.9685329219\end{array}$
C $5.1587735156 \quad 1.1704486208 \quad 3.1315823919$
H $\quad-4.3600666339 \quad 3.8485446346 \quad 2.6574296926$
H $\quad-0.9238807381 \quad-5.8745742932 \quad 3.8057382934$
H $\quad \begin{array}{llll}5.7554812521 & 2.0736455648 & -3.0921395249\end{array}$
H $\quad-4.3600666339 \quad 3.8485446346 \quad-2.6574296926$
$\mathrm{H} \quad-0.9238807381 \quad-5.8745742932 \quad-3.8057382934$
H $5.7554812521 \quad-2.0736455648 \quad-3.0921395249$
$\mathrm{H} \quad-0.9238807381 \quad 5.8745742932 \quad-3.8057382934$
H $\quad-4.3600666339 \quad-3.8485446346-2.6574296926$
H $\quad 5.7554812521 \quad-2.0736455648 \quad 3.0921395249$
$\mathrm{H} \quad-0.9238807381 \quad 5.8745742932 \quad 3.8057382934$
H $\quad-4.3600666339-3.8485446346 \quad 2.6574296926$
H $\quad 5.7554812521 \quad 2.0736455648 \quad 3.0921395249$
$\mathrm{N} \quad-2.6727733611 \quad 4.9237801954 \quad 3.2179376704$
N $\quad-2.6727733611 \quad-4.9237801954 \quad 3.2179376704$
N 5.8354151668 0. $\quad-3.0983075847$
$\mathrm{N} \quad-2.6727733611 \quad 4.9237801954 \quad-3.2179376704$
$\mathrm{N}-2.6727733611 \quad-4.9237801954-3.2179376704$
$\begin{array}{llll}\mathrm{N} & 5.8354151668 & 0 . & 3.0983075847\end{array}$
C $\quad-3.3613052207 \quad 6.2176643175 \quad 2.9027905283$
$\begin{array}{llll}\text { C } & -3.3613052207 & -6.2176643175 & 2.9027905283\end{array}$
C $7.3233707236 \quad 0 . \quad-2.8859965242$
$\begin{array}{llll}\text { C } & -3.3613052207 & 6.2176643175 & -2.9027905283\end{array}$
C $-3.3613052207 \quad-6.2176643175 \quad-2.9027905283$
C $7.3233707236 \quad 0.2 .8859965242$
H $\quad-4.3628247717 \quad 6.1629596429 \quad 3.334838952$
H $\quad-2.7897255093 \quad-7.0111945901 \quad 3.3881978443$
H $7.7115375603 \quad 0.8948840718 \quad-3.3761716778$
H $\quad-4.3628247717 \quad 6.1629596429 \quad-3.334838952$
H $\quad-2.7897255093 \quad-7.0111945901 \quad-3.3881978443$
H $7.7115375603 \quad-0.8948840718 \quad-3.3761716778$
H $\quad-2.7897255093 \quad 7.0111945901 \quad-3.3881978443$

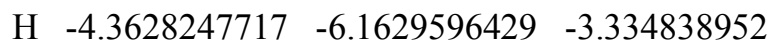
H $7.7115375603 \quad-0.8948840718 \quad 3.3761716778$
H $\quad-2.7897255093 \quad 7.0111945901 \quad 3.3881978443$
H $\quad-4.3628247717 \quad-6.1629596429 \quad 3.334838952$
H $7.7115375603 \quad 0.8948840718 \quad 3.3761716778$
$\begin{array}{llll}\text { C } & -3.4107936527 & 6.3769034885 & 1.4007585023\end{array}$
$\begin{array}{llll}\text { C } & -3.4107936527 & -6.3769034885 & 1.4007585023\end{array}$
C $7.5969222854 \quad 0 . \quad-1.4006284522$
$\begin{array}{llll}\text { C } & -3.4107936527 & 6.3769034885 & -1.4007585023\end{array}$
$\begin{array}{llll}\text { C } & -3.4107936527 & -6.3769034885 & -1.4007585023\end{array}$
C 7.5969222854 0. 1.4006284522
$\begin{array}{llll}\text { C } & -4.5731513264 & 6.0419776916 & 0.6984136142\end{array}$
$\begin{array}{llll}\text { C } & -2.257813926 & -6.7533489994 & 0.6965502987\end{array}$
$\begin{array}{llll}\text { C } & 7.6519677059 & 1.21048009 & -0.6977846771\end{array}$
C $\quad-4.5731513264 \quad 6.0419776916 \quad-0.6984136142$
$\begin{array}{llll}\text { C } & -2.257813926 & -6.7533489994 & -0.6965502987\end{array}$ 


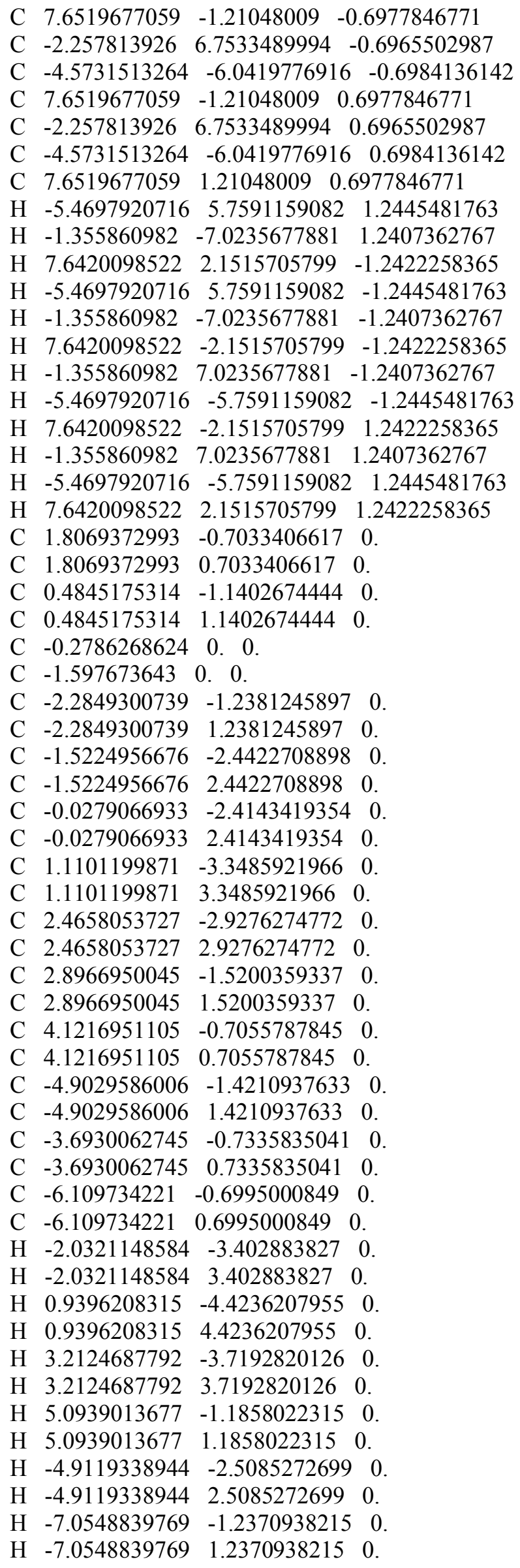


iCor (bowl) in ExCage - water solvent

Positive Definite Force Field

164

\begin{tabular}{|c|c|c|c|}
\hline & 26 & -7 . & \\
\hline & -1.4148261466 & -7.8490176609 & \\
\hline & -3.0724861687 & -6.5446673851 & -0 \\
\hline & -3.0191036358 & -6.8035697933 & -2 \\
\hline & 1971 & 332 & -2 \\
\hline & & 872 & \\
\hline & .5231972607 & & \\
\hline & & -4.225 & \\
\hline & 82 & & \\
\hline & & & \\
\hline & 259 & & \\
\hline & 3998 & -0.79 & \\
\hline & 076 & -0.9 & \\
\hline & -1.0 & & \\
\hline $\mathrm{C}$ & & 0.68 & \\
\hline 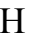 & 0 & 1.68 & -3.9 \\
\hline & 55 & 1.6 & -3. \\
\hline & 27 & 1.5 & -3.1 \\
\hline & 26 & 0.6 & -2.6 \\
\hline & & & \\
\hline & & 2.62 & -2.4 \\
\hline$C$ & & & \\
\hline 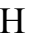 & -2 & 4.99 & -4.5 \\
\hline & -1.6 & 2.9 & -4.3 \\
\hline 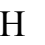 & -0.7 & 3.0 & -4 \\
\hline 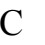 & -4.5 & 5.05 & -3.2 \\
\hline & & & \\
\hline & & 707 & 005 \\
\hline$C$ & & & -1. \\
\hline$\Pi$ & 5 & & \\
\hline & -4. & 5.5 & \\
\hline$r$ & $-5.1<-1$ & 5.14 & -0.7 \\
\hline & -5. & 4.520 & -1.0 \\
\hline$\sqrt{ }$ & -2.7 & -5.6 & -2 \\
\hline$\sqrt{ }$ & -3.6 & 3.8 & -3.4 \\
\hline 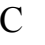 & & 16 & \\
\hline $\mathrm{H}$ & & & \\
\hline & & & \\
\hline & 8 & -5.5 & 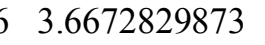 \\
\hline & -2.4 & -6.26 & 5511 \\
\hline & -0.9 & -4.2006363 & 109 \\
\hline $\mathrm{H}$ & -0.4 & $157 \mathrm{~T}$ & 3.376 \\
\hline $\bar{C}$ & 1 & & 3.4 \\
\hline $\mathrm{H}$ & & & \\
\hline & & & \\
\hline & -0.1 & -0.4892440865 & 3.59 \\
\hline & & 0.705 & 3.42 \\
\hline & & & \\
\hline & -0.2 & 1.94 & 336 \\
\hline & & & \\
\hline 11 & 8568 & 6 & 3.36 \\
\hline & 2 & 91176475 & 3.220145769 \\
\hline
\end{tabular}



C $\quad-2.3638765938 \quad 3.2710224489 \quad 3.6057158048$
H $\quad-2.8666991415 \quad 2.4432539037 \quad 4.0902416799$
$\begin{array}{llll}\text { C } & -3.0960748468 & 4.4142514274 & 3.3533319569\end{array}$
H $\quad-4.1497529043 \quad 4.4998664846 \quad 3.5902656908$
C $-1.2071078192 \quad 5.4733123876 \quad 2.4419477052$
$\mathrm{H} \quad-0.81378501 \quad 6.3702156529 \quad 1.9797828925$
C $\quad-0.4385670062 \quad 4.3519641375 \quad 2.6660809332$
$\begin{array}{llll}\mathrm{H} & 0.5972395279 & 4.383227899 & 2.3536091511\end{array}$
C $\quad-3.3803539044 \quad 6.6131560085 \quad 2.2642107335$
$\begin{array}{llll}\mathrm{H} & -4.2556078087 & 6.662594708 & 2.9150602217\end{array}$
H $\quad-2.7900306333 \quad 7.52714246692 .3575438102$
$\begin{array}{llll}\text { C } & -2.9186469564 & 6.7573298095 & -0.2135559629\end{array}$
$\begin{array}{llll}\text { H } & -2.0598118029 & 7.3856918041 & 0.0094043649\end{array}$
$\begin{array}{llll}\text { C } & -3.7518326436 & 6.3241824017 & 0.8270173824\end{array}$
$\begin{array}{llll}\text { C } & -4.867630089 & 5.5303834561 & 0.5368022326\end{array}$
H $\quad-5.5189354978 \quad 5.1991543157 \quad 1.3420578929$
N $-2.2463750925 \quad-4.2250231208 \quad 3.7817671946$
$\begin{array}{llll}\mathrm{N} & -2.5245690149 & 5.4844814374 & 2.7564948476\end{array}$
$\begin{array}{llll}\text { C } & -4.0126475074 & -5.6481026239 & 0.0044394202\end{array}$
$\mathrm{H} \quad-4.7420704169-5.1789014435 \quad-0.651826003$
H $\quad-4.0137451934-6.9338835209-2.4446673002$
C $\quad-3.1691211601-4.7420606273-3.3802508773$
$\mathrm{H} \quad-4.2132512875 \quad-5.0046486373-3.5011329455$
C $-2.6330437897 \quad-3.5631873429-3.8605253959$
H $\quad-3.2896425033 \quad-2.8864779961 \quad-4.3945584492$
$\begin{array}{llll}\text { C } & 0.6569411745 & -1.7064643383 & -4.0108453099\end{array}$
$\mathrm{H} \quad 1.3137825494 \quad-2.5669878003 \quad-4.0361554858$
$\begin{array}{llll}\text { C } & 1.2034787125 & -0.4153682205 & -4.0490056545\end{array}$
$\begin{array}{llll}\text { C } & 2.6641724991 & -0.2113297534 & -3.9336173873\end{array}$
$\begin{array}{llll}\text { C } & 3.5042315867 & -1.22188943 & -3.4222561584\end{array}$
H $3.1221842729 \quad-2.1924783025 \quad-3.1366321939$
C $4.845473218 \quad-0.9847339618 \quad-3.212742843$
H $5.5138330958 \quad-1.7323751958 \quad-2.8040125845$
C $4.624398002 \quad 1.2107596492 \quad-4.0152828775$
H $\quad 5.12617309392 .1463203611 \quad-4.2314076448$
C $3.2757813558 \quad 1.0172952434 \quad-4.2471150298$
H $2.7156323393 \quad 1.8414766394 \quad-4.6721728372$
$\begin{array}{lllll}\text { C } & 6.8453682594 & 0.4517518304 & -3.2122520037\end{array}$
H $7.3825574333 \quad-0.4068898458 \quad-3.6218900518$
H $7.1318110094 \quad 1.3540731517 \quad-3.7557689424$
C $6.8696570005 \quad 1.8227175139 \quad-1.0902677672$
H $\quad 6.5349702285 \quad 2.6786824771 \quad-1.6714549746$
$\begin{array}{llll}\text { C } & 7.0970164717 & 0.5951717652 & -1.7287987417\end{array}$
C $7.5434127689 \quad-0.4987290683 \quad-0.9789243183$
H $7.7332383269-1.4481810252 \quad-1.4735444203$
$\begin{array}{lllll}\mathrm{N} & 5.3910194937 & 0.2216623924 & -3.5004908865\end{array}$
$\begin{array}{llll}\text { C } & -4.0035890704 & -5.343976399 & 1.364911619\end{array}$
H $\quad-4.7231821979-4.6360355098 \quad 1.7693639876$
H $\quad-3.9630938191 \quad-5.38179201394 .1071995331$
$\begin{array}{llll}\text { C } & -2.9223387948 & -3.074848484 & 4.0024735615\end{array}$
$\mathrm{H} \quad-3.9855351475-3.1666032942 \quad 4.1885418794$
$\begin{array}{llll}\text { C } & -2.2728201868 & -1.8566626247 & 3.9715084418\end{array}$
H $\quad-2.8646509093 \quad-0.972710093 \quad 4.1706823956$
$\begin{array}{llll}\text { C } & 1.2124929312 & -0.4302137494 & 3.6623934745\end{array}$
H $1.7647993438-1.3445742142 \quad 3.8278419801$
$\begin{array}{llll}\text { C } & 1.9066907454 & 0.7853427105 & 3.550971946\end{array}$
$\begin{array}{llll}\text { C } & 3.3870320021 & 0.8217669948 & 3.5096764586\end{array}$ 

$\begin{array}{llll}\text { C } & 4.1602488485 & -0.3547145464 & 3.4273034486\end{array}$
H $3.7207534824 \quad-1.3422551677 \quad 3.4673215109$
$\begin{array}{llll}\text { C } & 5.520774152 & -0.2921974969 & 3.2106505198\end{array}$
H $6.1313687004 \quad-1.177324299 \quad 3.0779977873$
C $5.46207332392 .051330811 \quad 3.2454549202$
$\begin{array}{lllll}\text { H } & 6.0305361364 & 2.9694764991 & 3.159856025\end{array}$
C $4.101412894 \quad 2.0373369798 \quad 3.4684356255$
H $3.6177530663 \quad 2.9990055111 \quad 3.575834053$
$\begin{array}{llll}\text { C } & 7.5500365314 & 0.9375613127 & 2.5505718093\end{array}$
H $8.09023389 \quad 0.0945735814 \quad 2.9857284116$
H $7.9927036846 \quad 1.8782205193 \quad 2.8850990912$
$\begin{array}{llll}\text { C } & 7.0653292251 & 1.9456359067 & 0.2839654625\end{array}$
H $\quad 6.8797555661 \quad 2.898662651 \quad 0.7730479865$
$\begin{array}{llll}\text { C } & 7.4822443976 & 0.8401887625 & 1.0408369648\end{array}$
$\begin{array}{llll}\text { C } & 7.731143564 & -0.3787543675 & 0.4006146254\end{array}$
H $8.0547615779 \quad-1.2367492518 \quad 0.9846509235$
$\begin{array}{lllll}\mathrm{N} & 6.1511558769 & 0.8980811756 & 3.0839730484\end{array}$
$\begin{array}{llll}\text { C } & 1.9536180607 & -0.0531247976 & -0.8375453469\end{array}$
$\begin{array}{llll}\text { C } & 1.7328992528 & -1.4561515857 & -0.7315654049\end{array}$
$\begin{array}{lllll}\text { C } & 0.6974215322 & 0.5887033273 & -0.9554185926\end{array}$
$\begin{array}{lllll}\text { C } & 0.3357627611 & -1.6885549883 & -0.779363001\end{array}$
$\begin{array}{llll}\text { C } & -0.2758130376 & -0.4309934717 & -0.9523332461\end{array}$
$\begin{array}{llll}\text { C } & -1.5004805792 & -0.1938847517 & -0.420687878\end{array}$
$\begin{array}{llll}\text { C } & -1.8860572876 & 1.1198380809 & -0.0191860772\end{array}$
$\begin{array}{llll}\text { C } & -2.2562183595 & -1.2414758524 & 0.1867205156\end{array}$
C $\quad-0.943069548 \quad 2.1513574332 \quad-0.0609753835$
$\begin{array}{llll}\text { C } & -1.6765950959 & -2.5075510472 & 0.3244349039\end{array}$
$\begin{array}{lllll}\text { C } & 0.4347415658 & 1.8665204207 & -0.4519186038\end{array}$
$\begin{array}{llll}\text { C } & -0.295350133 & -2.727776184 & -0.0890487908\end{array}$
$\begin{array}{llll}\text { C } & 1.6309423889 & 2.5928042825 & -0.0750014663\end{array}$
$\begin{array}{llll}\text { C } & 0.6249896992 & -3.7293405372 & 0.4084782339\end{array}$
$\begin{array}{llll}\text { C } & 2.8827487927 & 1.9791316747 & -0.006556358\end{array}$
$\begin{array}{llll}\text { C } & 2.0054739214 & -3.5277820779 & 0.4173585617\end{array}$
$\begin{array}{lllll}\text { C } & 3.0629565614 & 0.5727090386 & -0.2892508802\end{array}$
$\begin{array}{llll}\text { C } & 2.607036864 & -2.3014153564 & -0.0618900186\end{array}$
$\begin{array}{llll}\text { C } & 4.1001919395 & -0.332587294 & 0.1545987192\end{array}$
$\begin{array}{llll}\text { C } & 3.8831848087 & -1.7010764504 & 0.2716951699\end{array}$
$\begin{array}{llll}\text { C } & -4.0906817753 & 1.7994951087 & 1.2096530815\end{array}$
$\begin{array}{llll}\text { C } & -4.5058860123 & -0.9924418354 & 1.5035905964\end{array}$
$\begin{array}{llll}\text { C } & -3.1738052691 & 0.8982790209 & 0.6784232931\end{array}$
$\begin{array}{llll}\text { C } & -3.3904686949 & -0.522400347 & 0.8157435039\end{array}$
$\begin{array}{llll}\text { C } & -5.2171117184 & 1.3090833036 & 1.8901087207\end{array}$
$\begin{array}{llll}\text { C } & -5.4190252801 & -0.0682855748 & 2.0394612379\end{array}$
$\mathrm{H} \quad-1.181269825 \quad 3.1277989994 \quad 0.3513788562$
H $\quad-2.1866672929-3.2889643241 \quad 0.8806461042$
$\begin{array}{lllll}\mathrm{H} & 1.5453514492 & 3.6225873417 & 0.264047083\end{array}$
H $0.2306794573 \quad-4.6261494342 \quad 0.8796789116$
H $3.7208176958 \quad 2.5556726074 \quad 0.3779950198$
H $2.6314691613 \quad-4.2764890546 \quad 0.8989940244$
$\begin{array}{lllll}\text { H } & 5.0459491029 & 0.0728952292 & 0.4945330067\end{array}$
H $4.6663041121 \quad-2.3116491244 \quad 0.7162463501$
$\mathrm{H} \quad-3.9380635705 \quad 2.8682344253 \quad 1.0954447688$
H $-4.6683917222 \quad-2.0606090539 \quad 1.6238679415$
H $\quad-5.9385815025 \quad 2.0085652824 \quad 2.3055630095$
H $\quad-6.2953075726 \quad-0.4288624226 \quad 2.5727848467$ 
Corannulene (bowl) in ExCage - water solvent Positive Definite Force Field

156
$\begin{array}{llll}\text { C } & -2.0973950688 & -7.1725327134 & 0.3085293461\end{array}$
$\mathrm{H} \quad-1.346441579-7.8172825265 \quad-0.1415082741$
C $\quad-3.0871019946-6.5964851861 \quad-0.495523131$
C $-3.0489326065-6.7858688411 \quad-1.9948058781$
H $\quad-2.4285090484 \quad-7.6403668921 \quad-2.2746598359$
C $-1.1184467731 \quad-5.3335913129-2.4364102911$
H $\quad-0.5618019486-6.1015846303 \quad-1.9135628185$
$\begin{array}{llll}\text { C } & -0.5474903816 & -4.147825771 & -2.842726837\end{array}$
H $\quad 0.498501975-3.9919017194 \quad-2.6134488667$
C $-1.3303597795-3.1539075352-3.4640095708$
$\begin{array}{llll}\text { C } & -0.7731265282 & -1.8148898367 & -3.7372800955\end{array}$
$\begin{array}{llll}\text { C } & -1.6177502917 & -0.6973435865 & -3.7870106164\end{array}$
H $\quad-2.6902200738-0.8335432826 \quad-3.7184349702$
$\begin{array}{llll}\text { C } & -1.0941158227 & 0.5997936265 & -3.8717746162\end{array}$
$\begin{array}{llll}\text { C } & 0.2974795022 & 0.7725884948 & -3.9004822997\end{array}$
H $\quad 0.7030346898 \quad 1.7769310012-3.8709089118$
$\begin{array}{llll}\text { C } & -1.9863646953 & 1.7738307971 & -3.8296588214\end{array}$

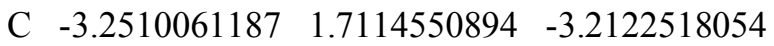
$\mathrm{H} \quad-3.6128036521 \quad 0.8015885186 \quad-2.7501934834$
C $\quad-4.0460310889 \quad 2.8342402096 \quad-3.1373937113$
H $\quad-5.0133202163 \quad 2.8359345419$-2.649762784
C $-2.4288006257 \quad 4.1117699891 \quad-4.2698924991$
$\mathrm{H} \quad-2.1653559348 \quad 5.0870100933-4.6615551705$
C $-1.601091987 \quad 3.0109912083-4.3781823207$
H $\quad-0.6565587673 \quad 3.1286280097 \quad-4.896620135$
C $-4.452209013 \quad 5.2447574959-3.4048709286$
H $\quad-5.4945851549 \quad 4.9698236047 \quad-3.5789144732$
H $\quad-4.1372639624 \quad 5.9909753458 \quad-4.1366356361$
C $-3.0882791225 \quad 6.4608087064 \quad-1.6657853028$
H $\quad-2.4196174717 \quad 6.7909062325 \quad-2.4574563815$
C $\quad-4.224457076 \quad 5.7052575846-1.9843645384$
$\begin{array}{llll}\text { C } & -5.0949501728 & 5.2978109161 & -0.9660597085\end{array}$
H $\quad-5.986281895 \quad 4.7268311897 \quad-1.2149239972$
$\begin{array}{llll}\mathrm{N} & -2.4378664777 & -5.5711224307 & -2.6269849817\end{array}$
$\begin{array}{llll}\mathrm{N} & -3.6282810759 & 4.0161947953 & -3.6515190005\end{array}$
C $-2.0630127807 \quad-6.9072764276 \quad 1.6790085049$
H $-1.2859964517 \quad-7.3474520611 \quad 2.2993993934$
$\begin{array}{llll}\text { C } & -3.0169062248 & -6.0616523179 & 2.2560171995\end{array}$
$\begin{array}{llll}\text { C } & -2.8998839917 & -5.6727518576 & 3.7116698065\end{array}$
H $\quad-2.3188730401 \quad-6.4047351607 \quad 4.27727467$
C $-0.8357221558 \quad-4.34109180593 .5992580052$
$\begin{array}{llll}\mathrm{H} & -0.3535697784 & -5.299455543 & 3.4513542825\end{array}$
C $-0.1496675309 \quad-3.1479975109 \quad 3.5314380171$
H $0.9077914193 \quad-3.1960995138 \quad 3.3083123064$
C $\quad-0.8256602998 \quad-1.9223640551 \quad 3.689181602$
$\begin{array}{llll}\text { C } & -0.1220428385 & -0.6288103519 & 3.5601158671\end{array}$
$\begin{array}{llll}\text { C } & -0.8395689683 & 0.5521395162 & 3.3161477567\end{array}$
H $\quad-1.9096218286 \quad 0.5026637509 \quad 3.1605235987$
$\begin{array}{llll}\text { C } & -0.1881424812 & 1.7917009416 & 3.2296561219\end{array}$
C $\quad 1.2106228733 \quad 1.8236881663 \quad 3.3120264196$
H $1.7186923346 \quad 2.7722141736 \quad 3.2138367941$
C $\quad-0.9590332808 \quad 3.0376513884 \quad 3.0366749521$ 

C $\quad-2.337030786 \quad 3.1031201236 \quad 3.3235996653$
$\mathrm{H} \quad-2.8728000307 \quad 2.2605013192 \quad 3.743033718$
C $\quad-3.0523401046 \quad 4.256466147 \quad 3.0735543808$
H $\quad-4.1173592526 \quad 4.3387522996 \quad 3.2553404668$
C $-1.111318877 \quad 5.3491693923 \quad 2.3287121336$
$\mathrm{H} \quad-0.6879422515 \quad 6.2632822011 \quad 1.9302753282$
$\begin{array}{llll}\text { C } & -0.3575203797 & 4.2175183015 & 2.5561579455\end{array}$
$\begin{array}{lllll}\mathrm{H} & 0.6950962597 & 4.2677224757 & 2.3117069477\end{array}$
C $\quad-3.2670958133 \quad 6.5286464496 \quad 2.1332159414$
H $\quad-4.1390908731 \quad 6.56788933342 .7887161945$
H $\quad-2.6537456302 \quad 7.4212831408 \quad 2.2730923287$
$\begin{array}{llll}\text { C } & -2.8044893943 & 6.7705464901 & -0.3358502254\end{array}$
H $\quad-1.9147769166 \quad 7.3439651754 \quad-0.0869018937$
$\begin{array}{lllll}\text { C } & -3.6540903647 & 6.3273804326 & 0.6865728196\end{array}$
$\begin{array}{llll}\text { C } & -4.8104990099 & 5.6069624579 & 0.3650202537\end{array}$
H $\quad-5.4769518008 \quad 5.2749712343 \quad 1.1576539505$
$\begin{array}{lllll}\mathrm{N} & -2.1716928987 & -4.3649440699 & 3.8145279887\end{array}$
$\begin{array}{llll}\mathrm{N} & -2.442794961 & 5.3552590682 & 2.5702738373\end{array}$
$\begin{array}{llll}\text { C } & -4.0630752246 & -5.7759759935 & 0.0878487414\end{array}$
$\mathrm{H} \quad-4.8379012361 \quad-5.333120612-0.5337816051$
H $\quad-4.0471107665-6.8977283665-2.4222510326$
C $-3.2101534675-4.6683411875 \quad-3.2741671958$
H $\quad-4.2518416486-4.9331198714 \quad-3.4106208124$
C $-2.6800950988-3.4693354522 \quad-3.7097997312$
H $\quad-3.3400120552-2.7812099928 \quad-4.2245800487$
$\begin{array}{llll}\text { C } & 0.6137364117 & -1.6166921552 & -3.8112350861\end{array}$
$\mathrm{H} \quad 1.2703167516 \quad-2.4775054287 \quad-3.8195985834$
C $1.165621032-0.3293096044-3.8688280476$
$\begin{array}{llll}\text { C } & 2.6279860074 & -0.1325884399 & -3.7751374438\end{array}$
C $3.4676708236-1.1360018286-3.252876696$
H $3.0812414062 \quad-2.0901030729-2.9211071749$
$\begin{array}{llll}\text { C } & 4.8173027302 & -0.9092335869 & -3.0918979096\end{array}$
H $5.4878943204-1.6508465372-2.676298762$
C $4.6009726193 \quad 1.2612998503 \quad-3.9612664608$
H $\quad \begin{array}{llll}5.1092413809 & 2.18138688 & -4.2235329364\end{array}$
$\begin{array}{llll}\text { C } & 3.2439553571 & 1.0784607421 & -4.144621086\end{array}$
H $2.6797586633 \quad 1.8944786071 \quad-4.5794383825$
C $6.8344250881 \quad 0.4964200521 \quad-3.197960105$
H $7.3523030691 \quad-0.3618815031 \quad-3.6325537752$
H $7.1075136472 \quad 1.4039440801 \quad-3.7393306541$
C $6.9586028904 \quad 1.8497522936-1.068451433$
H $\quad 6.6588229605 \quad 2.7258138054 \quad-1.6385896186$
$\begin{array}{llll}\text { C } & 7.1238844622 & 0.6198061019 & -1.7207088744\end{array}$
C $7.5226561635-0.502575346-0.9861365881$
H $7.667096662-1.4540925199-1.4917940056$
N $5.3695896782 \quad 0.2775329137 \quad-3.4391219312$
C $\quad-4.0276882543 \quad-5.5093067935 \quad 1.4560515575$
H $\quad-4.7742593664 \quad-4.8579922373 \quad 1.9043760186$
$\mathrm{H} \quad-3.875476798 \quad-5.5300553678 \quad 4.1802817655$
C $-2.8533025778 \quad-3.2118722638 \quad 4.004813311$
$\mathrm{H} \quad-3.9180527597 \quad-3.3049646601 \quad 4.1815304789$
C $\quad-2.206257827 \quad-1.9927773926 \quad 3.9596147657$
H $\quad-2.8000340923 \quad-1.1047159529 \quad 4.1380657567$
C $1.2757783351 \quad-0.5590563286 \quad 3.6692360905$
H $1.8301395672 \quad-1.4592587931 \quad 3.8989928149$
$\begin{array}{llll}\text { C } & 1.9621500781 & 0.655484525 & 3.5144610738\end{array}$
$\begin{array}{llll}\text { C } & 3.4407830508 & 0.705683282 & 3.4976937086\end{array}$ 

C $4.2183167665 \quad-0.4619509764 \quad 3.3608241673$
H $3.776191395 \quad-1.4490856178 \quad 3.3409638129$
$\begin{array}{llll}\text { C } & 5.5794718812 & -0.3817401745 & 3.1580433907\end{array}$
$\begin{array}{lllll}\mathrm{H} & 6.1968319014 & -1.2550085211 & 2.9865398478\end{array}$
$\begin{array}{llll}\text { C } & 5.5066055256 & 1.9590379369 & 3.3023890397\end{array}$
$\begin{array}{llll}\text { H } & 6.0707994418 & 2.8829137991 & 3.2593158067\end{array}$
C $4.1459095657 \quad 1.9263121842 \quad 3.525553929$
H $3.6525129842 \quad 2.8755794748 \quad 3.6905998655$
$\begin{array}{llll}\text { C } & 7.6011340073 & 0.8851350599 & 2.5584697955\end{array}$
$\begin{array}{llll}\mathrm{H} & 8.1495427946 & 0.0402736435 & 2.9793700496\end{array}$
$\begin{array}{llll}\text { H } & 8.0333213094 & 1.8241944956 & 2.909908059\end{array}$
C $7.1647055263 \quad 1.9472910615 \quad 0.30700453$
H $7.0233360523 \quad 2.9004067695 \quad 0.8107879311$
$\begin{array}{llll}\text { C } & 7.5313774597 & 0.8141842668 & 1.0480083742\end{array}$
$\begin{array}{llll}\text { C } & 7.7208318102 & -0.4075534626 & 0.3929890029\end{array}$
$\begin{array}{lllll}\mathrm{H} & 8.0083317088 & -1.286109149 & 0.965196831\end{array}$
$\begin{array}{llll}\mathrm{N} & 6.2014182438 & 0.8179251224 & 3.0880549532\end{array}$
$\begin{array}{llll}\text { C } & 1.7713746221 & 0.0590820182 & -0.6920706114\end{array}$
$\begin{array}{llll}\text { C } & 1.6313981805 & -1.3393963244 & -0.5646579761\end{array}$
$\begin{array}{llll}\text { C } & 0.4803479373 & 0.6246568432 & -0.743515985\end{array}$
$\begin{array}{llll}\text { C } & 0.2520233112 & -1.6368234471 & -0.5301879097\end{array}$
$\begin{array}{llll}\text { C } & -0.4589977125 & -0.4228076031 & -0.6403342089\end{array}$
$\begin{array}{llll}\text { C } & -1.7445998465 & -0.2459440895 & -0.1555285007\end{array}$
C $\quad-2.1160718948 \quad 1.1423697721 \quad 0.0252485858$
$\begin{array}{llll}\text { C } & -2.3768515847 & -1.472021907 & 0.2912220501\end{array}$
$\begin{array}{llll}\text { C } & -1.191608926 & 2.1808685757 & -0.0963728438\end{array}$
C $\quad-1.6751639058-2.67379735350 .3946364156$
$\begin{array}{lllll}\text { C } & 0.2063024333 & 1.9355984606 & -0.3887746784\end{array}$
$\begin{array}{lllll}\text { C } & -0.266935856 & -2.771497907 & 0.071514164\end{array}$
C $\quad 1.3920481732 \quad 2.7350880246 \quad-0.1429221579$
$\begin{array}{llll}\text { C } & 0.7384067095 & -3.7329368016 & 0.4785267093\end{array}$
$\begin{array}{llll}\text { C } & 2.6690855634 & 2.1728973329 & -0.0821017946\end{array}$
$\begin{array}{llll}\text { C } & 2.1023079103 & -3.4380109559 & 0.4478555076\end{array}$
$\begin{array}{llll}\text { C } & 2.8937824145 & 0.7543426688 & -0.2741552105\end{array}$
$\begin{array}{llll}\text { C } & 2.6013170813 & -2.1525812673 & -0.0013242416\end{array}$
$\begin{array}{llll}\text { C } & 3.9993498661 & -0.0969537344 & 0.1064375187\end{array}$
$\begin{array}{llll}\text { C } & 3.8606792124 & -1.4792965282 & 0.2394808804\end{array}$
H $1.2875926756 \quad 3.7935219493 \quad 0.0831186706$
H $\quad 0.4265468981 \quad-4.6857040608 \quad 0.8993372283$
$\begin{array}{llll}\mathrm{H} & 3.5022559211 & 2.813897633 & 0.1981558188\end{array}$
H $2.7966778198 \quad-4.1711657275 \quad 0.8537180943$
$\begin{array}{lllll}\mathrm{H} & 4.9492524366 & 0.3524624843 & 0.3777429765\end{array}$
H $4.7099720173-2.0441644413 \quad 0.6168068069$
$\mathrm{H} \quad-3.4070101953-1.44806130620 .6411302667$
H $-2.1909237728-3.5353323311 \quad 0.8104365891$
$\begin{array}{llll}\mathrm{H} & -1.5280447371 & 3.190936843 & 0.1206850335\end{array}$
$\begin{array}{llll}\mathrm{H} & -3.126814762 & 1.3917909313 & 0.3412995809\end{array}$

Corannulene (flat) in ExCage - water solvent Transition State, Imaginary Mode -89.9567

156

$\begin{array}{llll}\text { C } & 0.819588605 & -1.2024715111 & 3.353377676\end{array}$

$\begin{array}{llll}\text { C } & 0.819588605 & 1.2024715111 & 3.353377676\end{array}$

$\begin{array}{llll}\text { C } & -1.2634526721 & 0 . & -3.570264229\end{array}$

$\begin{array}{llll}\text { C } & 0.819588605 & -1.2024715111 & -3.353377676\end{array}$ 

C $\quad 0.819588605 \quad 1.2024715111 \quad-3.353377676$
C $-1.2634526721 \quad 0.3 .570264229$
H $1.340418361 \quad-2.1435601072 \quad 3.2476339205$
H $1.340418361 \quad 2.1435601072 \quad 3.2476339205$
$\mathrm{H} \quad-2.3354285871 \quad 0 . \quad-3.7246671257$
H $1.340418361 \quad-2.1435601072 \quad-3.2476339205$
H $1.340418361 \quad 2.1435601072 \quad-3.2476339205$
H $\quad-2.3354285871 \quad 0 . \quad 3.7246671257$
C $\quad-0.5770060261 \quad 1.2196632998 \quad 3.4820011026$
$\begin{array}{llll}\text { C } & -0.5770060261 & -1.2196632998 & 3.4820011026\end{array}$
C $1.54270270920 . \quad-3.3216962902$
$\begin{array}{llll}\text { C } & -0.5770060261 & 1.2196632998 & -3.4820011026\end{array}$
C $\quad-0.5770060261 \quad-1.2196632998 \quad-3.4820011026$
C $1.5427027092 \quad 0.3 .3216962902$
$\begin{array}{llll}\text { C } & -1.3067383448 & 2.504441684 & 3.4767635519\end{array}$
$\begin{array}{llll}\text { C } & -1.3067383448 & -2.504441684 & 3.4767635519\end{array}$
C $3.0235875199 \quad 0 . \quad-3.2542389208$
C $\quad-1.3067383448 \quad 2.504441684-3.4767635519$
$\begin{array}{llll}\text { C } & -1.3067383448 & -2.504441684 & -3.4767635519\end{array}$
C 3.0235875199 0. 3.2542389208
C $\quad-2.6722804571 \quad 2.5718384261 \quad 3.134328412$
$\begin{array}{llll}\text { C } & -0.6647933967 & -3.7243779881 & 3.762539414\end{array}$
$\begin{array}{llll}\text { C } & 3.7707486383 & 1.195004881 & -3.2250298759\end{array}$
$\begin{array}{llll}\text { C } & -2.6722804571 & 2.5718384261 & -3.134328412\end{array}$
$\begin{array}{llll}\text { C } & -0.6647933967 & -3.7243779881 & -3.762539414\end{array}$
$\begin{array}{llll}\text { C } & 3.7707486383 & -1.195004881 & -3.2250298759\end{array}$
C $\quad-0.6647933967 \quad 3.7243779881 \quad-3.762539414$
$\begin{array}{llll}\text { C } & -2.6722804571 & -2.5718384261 & -3.134328412\end{array}$
C $3.7707486383 \quad-1.195004881 \quad 3.2250298759$
$\begin{array}{llll}\text { C } & -0.6647933967 & 3.7243779881 & 3.762539414\end{array}$
$\begin{array}{llll}\text { C } & -2.6722804571 & -2.5718384261 & 3.134328412\end{array}$
C $3.7707486383 \quad 1.195004881 \quad 3.2250298759$
H $\quad-3.2452349967 \quad 1.6848282765 \quad 2.8971857784$
H $\quad 0.3684630284 \quad-3.7656556438 \quad 4.0853088122$
H $3.3042303761 \quad 2.1707056426 \quad-3.2468989052$
H $\quad-3.2452349967 \quad 1.6848282765 \quad-2.8971857784$

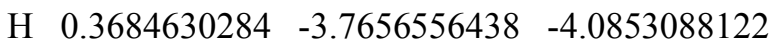
H $3.3042303761 \quad-2.1707056426 \quad-3.2468989052$
$\mathrm{H} \quad 0.3684630284 \quad 3.7656556438 \quad-4.0853088122$
H $\quad-3.2452349967 \quad-1.6848282765 \quad-2.8971857784$
H $3.3042303761 \quad-2.1707056426 \quad 3.2468989052$
H $\quad 0.3684630284 \quad 3.7656556438 \quad 4.0853088122$

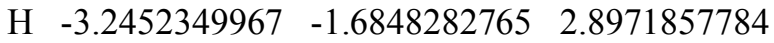
H $3.3042303761 \quad 2.1707056426 \quad 3.2468989052$
$\begin{array}{llll}\text { C } & -3.3075856079 & 3.7893208458 & 3.0253530702\end{array}$
C $-1.3390230202-4.9219784907 \quad 3.6251550696$
$\begin{array}{llll}\text { C } & 5.1486143921 & 1.1709665171 & -3.151636729\end{array}$
C $\quad-3.3075856079 \quad 3.7893208458 \quad-3.0253530702$
$\begin{array}{llll}\text { C } & -1.3390230202 & -4.9219784907 & -3.6251550696\end{array}$
C $5.1486143921 \quad-1.1709665171 \quad-3.151636729$
C $\quad-1.3390230202 \quad 4.9219784907 \quad-3.6251550696$
$\begin{array}{llll}\text { C } & -3.3075856079 & -3.7893208458 & -3.0253530702\end{array}$
$\begin{array}{llll}\text { C } & 5.1486143921 & -1.1709665171 & 3.151636729\end{array}$
C $\quad-1.3390230202 \quad 4.9219784907 \quad 3.6251550696$
$\begin{array}{llll}\text { C } & -3.3075856079 & -3.7893208458 & 3.0253530702\end{array}$
$\begin{array}{llll}\text { C } & 5.1486143921 & 1.1709665171 & 3.151636729\end{array}$
H $\quad-4.3441912283 \quad 3.8847609478 \quad 2.7250674343$ 

$\begin{array}{llll}\mathrm{H} & -0.8690252188 & -5.8824383191 & 3.7994466908\end{array}$
H $5.7460407416 \quad 2.0735454111 \quad-3.1102576512$
H $\quad-4.3441912283 \quad 3.8847609478 \quad-2.7250674343$

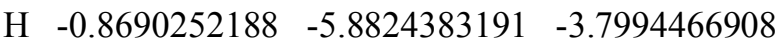
H $5.7460407416 \quad-2.0735454111 \quad-3.1102576512$
H $-0.8690252188 \quad 5.8824383191 \quad-3.7994466908$
$\mathrm{H} \quad-4.3441912283 \quad-3.8847609478 \quad-2.7250674343$
H $5.7460407416 \quad-2.0735454111 \quad 3.1102576512$
$\begin{array}{lllll}\mathrm{H} & -0.8690252188 & 5.8824383191 & 3.7994466908\end{array}$
H $\quad-4.3441912283 \quad-3.8847609478 \quad 2.7250674343$
H $\quad 5.7460407416 \quad 2.0735454111 \quad 3.1102576512$
N $\quad-2.6355221574 \quad 4.9455395276 \quad 3.2422017034$
$\begin{array}{llll}\mathrm{N} & -2.6355221574 & -4.9455395276 & 3.2422017034\end{array}$
N $5.8237581157 \quad 0 . \quad-3.1147668992$
N $-2.6355221574 \quad 4.9455395276 \quad-3.2422017034$
N $-2.6355221574-4.9455395276 \quad-3.2422017034$
$\begin{array}{llll}\mathrm{N} & 5.8237581157 & 0 . & 3.1147668992\end{array}$
$\begin{array}{llll}\text { C } & -3.305314841 & 6.2434095762 & 2.9054154137\end{array}$
$\begin{array}{llll}\text { C } & -3.305314841 & -6.2434095762 & 2.9054154137\end{array}$
C 7.3079026209 0. -2.8882909673
$\begin{array}{llll}\text { C } & -3.305314841 & 6.2434095762 & -2.9054154137\end{array}$
$\begin{array}{llll}\text { C } & -3.305314841 & -6.2434095762 & -2.9054154137\end{array}$
C 7.3079026209 0. 2.8882909673
H $\quad-4.3103562319 \quad 6.2070700979 \quad 3.3311305564$
H $\quad-2.7270725805 \quad-7.0353505898 \quad 3.3856849688$
H $7.70233712220 .8949219942 \quad-3.3733894939$
H $\quad-4.3103562319 \quad 6.2070700979 \quad-3.3311305564$
H $\quad-2.7270725805 \quad-7.0353505898 \quad-3.3856849688$
H $7.7023371222 \quad-0.8949219942 \quad-3.3733894939$
H $\quad-2.7270725805 \quad 7.0353505898 \quad-3.3856849688$
H $\quad-4.3103562319 \quad-6.2070700979 \quad-3.3311305564$
H $7.7023371222 \quad-0.8949219942 \quad 3.3733894939$
H $\quad-2.7270725805 \quad 7.0353505898 \quad 3.3856849688$
H $\quad-4.3103562319 \quad-6.20707009793 .3311305564$
H $7.7023371222 \quad 0.8949219942 \quad 3.3733894939$
$\begin{array}{llll}\text { C } & -3.3443987937 & 6.3890729587 & 1.4012806301\end{array}$
$\begin{array}{llll}\text { C } & -3.3443987937 & -6.3890729587 & 1.4012806301\end{array}$
$\begin{array}{llll}\text { C } & 7.5605332721 & 0 . & -1.3997675092\end{array}$
$\begin{array}{llll}\text { C } & -3.3443987937 & 6.3890729587 & -1.4012806301\end{array}$
$\begin{array}{llll}\text { C } & -3.3443987937 & -6.3890729587 & -1.4012806301\end{array}$
$\begin{array}{llll}\text { C } 7.5605332721 & 0 . & 1.3997675092\end{array}$
C $-4.5155735552 \quad 6.0879277455 \quad 0.6985179628$
$\begin{array}{llll}\text { C } & -2.1801309249 & -6.7287512514 & 0.6966344174\end{array}$
C $7.6069304054 \quad 1.2108267953 \quad-0.6975585224$
$\begin{array}{lllll}\text { C } & -4.5155735552 & 6.0879277455 & -0.6985179628\end{array}$
$\begin{array}{llll}\text { C } & -2.1801309249 & -6.7287512514 & -0.6966344174\end{array}$
C $7.6069304054 \quad-1.2108267953 \quad-0.6975585224$
$\begin{array}{llll}\text { C } & -2.1801309249 & 6.7287512514 & -0.6966344174\end{array}$
$\begin{array}{llll}\text { C } & -4.5155735552 & -6.0879277455 & -0.6985179628\end{array}$
C $7.6069304054-1.2108267953 \quad 0.6975585224$
$\begin{array}{llll}\text { C } & -2.1801309249 & 6.7287512514 & 0.6966344174\end{array}$
$\begin{array}{llll}\text { C } & -4.5155735552 & -6.0879277455 & 0.6985179628\end{array}$
$\begin{array}{llll}\text { C } & 7.6069304054 & 1.2108267953 & 0.6975585224\end{array}$
H $\quad-5.420523264 \quad 5.8332614396 \quad 1.2449348479$
H $\quad-1.2704985758 \quad-6.9729784936 \quad 1.2402517118$
H $7.5978203185 \quad 2.1516279335 \quad-1.2425057545$
H $\quad-5.4205232645 .8332614396 \quad-1.2449348479$ 


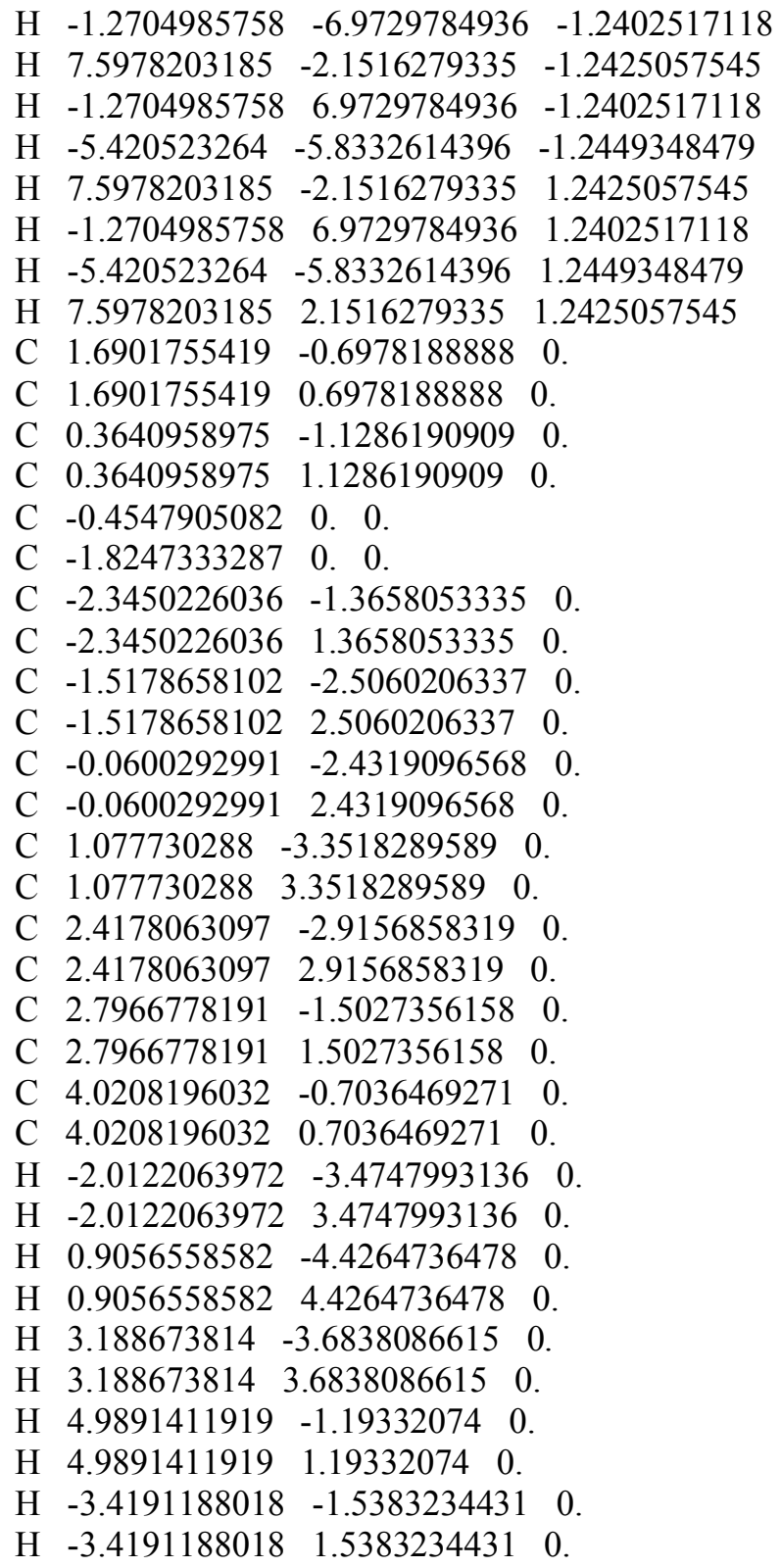




\section{S7. References}

(1) Wang, Y.; Allemann, O.; Balaban, T. S.; Vanthuyne, N.; Linden, A.; Baldridge, K. K.; Siegel, J. S. Chiral Atropisomeric Indenocorannulene Bowls: Critique of the CahnIngold-Prelog Conception of Molecular Chirality. Angew. Chem. Int. Ed. 2018, 57, $6470-6474$.

(2) Dale, E. J.; Vermeulen, N. A.; Thomas, A. A.; Barnes, J. C.; Juríček, M.; Blackburn, A. K.; Strutt, N. L.; Sarjeant, A. A.; Stern, C. L.; Denmark, S. E.; Stoddart, J. F. ExCage. J. Am. Chem. Soc. 2014, 136, 10669-10682.

(3) Lawton, R. G.; Barth, W. E. Synthesis of Corannulene. J. Am. Chem. Soc. 1971, 93, $1730-1745$.

(4) Clark, R. C.; Reid, J. S. The Analytical Calculation of Absorption in Multifaceted Crystals. Acta Crystallogr. Sect. A 1995, 51, 887-897.

(5) Dolomanov, O. V; Bourhis, L. J.; Gildea, R. J.; Howard, J. A. K.; Puschmann, H. OLEX2: A Complete Structure Solution, Refinement and Analysis Program. J. Appl. Crystallogr. 2009, 42, 339-341.

(6) Sheldrick, G. M. SHELXTIntegrated Space-Group and Crystal-Structure Determination. Acta Crystallogr. Sect. A 2015, 71, 3-8.

(7) Spek, A. L. Structure Validation in Chemical Crystallography. Acta Crystallogr. Sect. D 2009, 65, 148-155.

(8) Spek, A. L. PLATON SQUEEZE: A Tool for the Calculation of the Disordered Solvent Contribution to the Calculated Structure Factors. Acta Crystallogr. Sect. C 2015, 71, 918. 